\title{
Investigation of the Potential Impacts From Tritium Soil Contamination in the CP-5 Yard
}

\section{Decontamination and Decommissioning Program}

Argonne National Laboratory 9700 South Cass Avenue

Argonne, Illinois 60439
Operated by The University of Chicago, under Contract W-31-109-ENG-38, for the United States Department of Energy 


\section{Argonne National Laboratory}

Argonne National Laboratory, with facilities in the states of Illinois and Idaho, is owned by the United States Government, and operated by the University of Chicago under the provisions of a contract with the Department of Energy.

This final project report is a product of Argonne's Technology Development Division, Decontamination and Decommissioning Program. For information on the division's activities, contact:

Director, Technology Development Division

Argonne National Laboratory

Argonne, Illinois 60439-4814

Telephone (630) 252-3293

\section{Disclaimer}

This report was prepared as an account of work sponsored by an agency of the United States Government. Neither the United States Government nor any agency thereof, nor any of their employees, makes any warranty, express or implied, or assumes any legal liability or responsibility for the accuracy, completeness, or usefulness of any information, apparatus, product, or process disclosed, or represents that its use would not infringe privately owned rights. Reference herein to any specific commercial product, process, or service by trade name, trademark, manufacturer, or otherwise, does not necessarily constitute or imply its endorsement, recommendation, or favoring by the United States Government or any agency thereof. The views and opinions of authors expressed herein do not necessarily state or reflect those of the United States Government or any agency thereof.

Available to DOE and DOE contractors from the Office of Scientific and Technical Information, P.O. Box 62, Oak Ridge, TN 37831; prices available from (423) 576-8401.

Available to the public from the National Technical Information Service, U.S. Department of Commerce, 5285 Port Royal Road, Springfield, VA 22161. 
Investigation of the Potential Impacts from

Tritium Soil Contamination in the CP-5 Yard

Robert J. Hysong

Decontamination and Decommissioning Program

Technology Development Division

Argonne National Laboratory

9700 South Cass Avenue

Argonne, Illinois 60439

November 1998

Work sponsored by United States Department of Energy, Office of Environmental Management 


\section{ACKNOWLEDGEMENTS}

The CP-5 yard tritium contamination investigation and RESRAD dose assessment discussed in this report were conducted in support of the Argonne National Laboratory-East, Technology Development Division, Decontamination and Decommissioning Program. The author benefitted from insights and comments provided by other ANL-E personnel including $T$. Yule and F. Clark (Technology Development Division), C. Yu and J. Peterson (Environmental Assessment Division), S. Baker and N. Golchert (Environment, Safety and Health Division), E. Zimmerman (Energy Systems Division), and R. Rose (formerly Technology Development Division, currently Florida International University). 


\section{DISCLAIMER}

Portions of this document may be illegible in electronic image products. Images are produced from the best available original document. 
INVESTIGATION OF TRITIUM SOL

TABLE OF CONTENTS

$\underline{\text { Page }}$

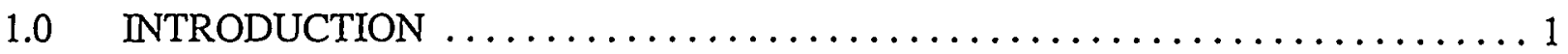

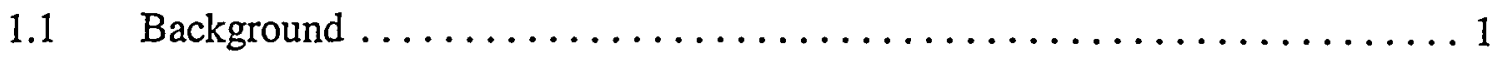

$1.2 \quad$ Purpose and Scope of This Investigation $\ldots \ldots \ldots \ldots \ldots \ldots \ldots \ldots$

2.0 GEOLOGY/HYDROGEOLOGY OF THE CP-5 SITE $\ldots \ldots \ldots \ldots \ldots \ldots \ldots$

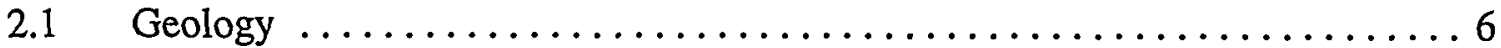

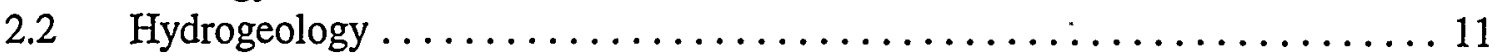

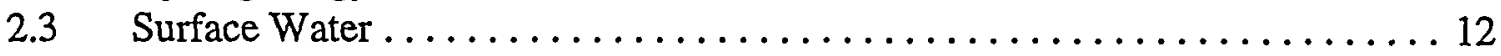

3.0 POTENTIAL SOURCES OF TRITIUM IN CP-5 YARD SOIL ............ 12

3.1 Tritium Releases From Primary to Secondary Cooling System . . . . . . . . 12

3.2 Draining Secondary System Water to Footing Drains .............. 13

3.3 Secondary System Water Leakage to CP-5 Yard Soil .............. 13

3.3.1 Tritiated Water Leaks From Cooling Tower Piping .......... 13

3.3.2 Tritiated Water Leaks From CP-5 Drain Tile System ......... 13

3.3.3 Tritiated Water Releases to a Storm Drain ............. 13

$3.4 \quad$ Fuel Pool Liner Hole Leakage .......................... 14

3.5 Water Identified in the Rod Storage Area Below-Grade Holes . . . . . . . . . 14

3.6 Airborne Tritium Fallout $\ldots \ldots \ldots \ldots \ldots \ldots \ldots \ldots \ldots \ldots \ldots \ldots \ldots$

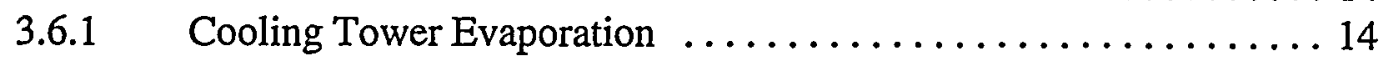

3.6.2 Ventilation System Stack $\ldots \ldots \ldots \ldots \ldots \ldots \ldots \ldots \ldots \ldots \ldots$

4.0 CP-5 RADIOLOGICAL MONITORING ...................... 15

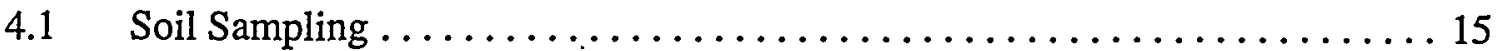

4.1.1 1980 CP-5 Area Soil Sampling Results .............. 15

4.1.2 1989 20-ft Soil Core Sampling Results .............. 17

4.1.3 1993 IT Corporation CP-5 Yard Characterization .......... 18

4.1.4 1997 Dolomite Well Installation .................... 18

4.1.5 1997 50-ft Deep Split-Spoon Sampling .............. 20

4.1.6 1998 Split-Spoon Sampling Adjacent to Fuel Pool ............ 21

4.1.7 1998 CP-5 Yard Sampling ....................... 21

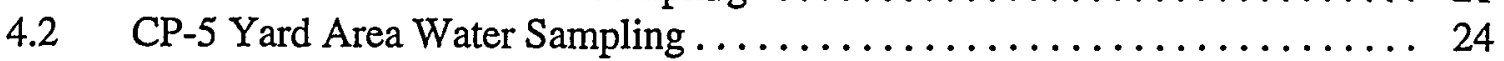

4.2.1 Shallow Groundwater Monitoring .................. 24

4.2.2 Dolomite Groundwater Monitoring ................ 27 


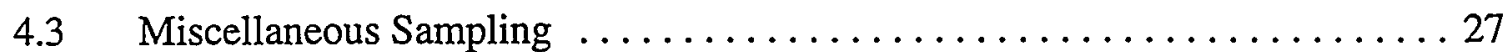

4.3.1 Results Fuel Pool Liner Investigation ................ 27

4.3.2 CP-5 Reactor Building Drain Tile System $\ldots \ldots \ldots \ldots \ldots \ldots 28$

5.0 RESRAD DOSE ASSESSMENT INPUT PARAMETERS $\ldots \ldots \ldots \ldots \ldots \ldots . \ldots$

6.0 RESULTS OF DETERMINISTIC DOSE ASSESSMENT ............. 34

$7.0 \quad$ PARAMETER SENSITIVITY ANALYSIS $\ldots \ldots \ldots \ldots \ldots \ldots \ldots \ldots \ldots \ldots \ldots \ldots$

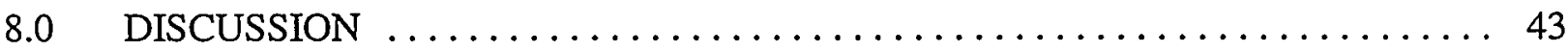

8.1 Residential Family-Farm Scenario Impacts $\ldots \ldots \ldots \ldots \ldots \ldots \ldots \ldots 43$

8.2 Industrial Use Scenario $\ldots \ldots \ldots \ldots \ldots \ldots \ldots \ldots \ldots \ldots \ldots, \ldots \ldots$

9.0 CONCLUSIONS/RECOMMENDATIONS $\ldots \ldots \ldots \ldots \ldots \ldots \ldots \ldots \ldots$

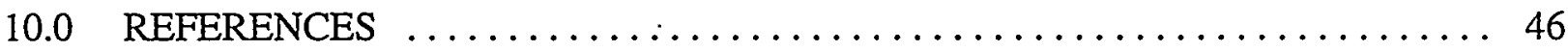

11.0 ACRONYMS AND ABBREVIATIONS $\ldots \ldots \ldots \ldots \ldots \ldots \ldots \ldots \ldots \ldots \ldots$

APPENDIX A Illinois Environmental Protection Agency Well Completed Report and Field Boring Log For Well \# MW330012D and Borehole \#330012D . . 49

APPENDIX B Stratigraphic column and Split-Spoon Core Log For Well \# MW33001 . . 54 APPENDIX C 1989 20-ft Soil Boring Sampling Results $\ldots \ldots \ldots \ldots \ldots \ldots \ldots \ldots$ APPENDIX D 1993 IT Corporation Radiological Sampling Results ............. 59 APPENDIX E Residential Family-Farm RESRAD Summary Report $\ldots \ldots \ldots \ldots \ldots 67$ APPENDIX F Residential Family-Farm RESRAD Detailed Report $\ldots \ldots \ldots \ldots \ldots . . .82$ 


\section{LIST OF FIGURES}

Figure $1.1 \quad$ Map of Argonne National Laboratory-East $\ldots \ldots \ldots \ldots \ldots \ldots \ldots \ldots$

Figure $1.2 \quad$ CP-5 Reactor Area and Monitoring Well Locations $\ldots \ldots \ldots \ldots \ldots \ldots$

Figure $1.3 \quad$ Location of Spent Fuel Pool in E-Wing .................... 4

Figure 1.4 Shallow Well 330011 Groundwater Monitoring Results ............. 5

Figure 2.1 Locations Selected for Detailed Geologic Study and Locations of Geologic Cross Sections at ANL-E . .............. 7

Figure 2.2 Locations Selected for Detailed Geologic Study and Locations of Geologic Cross Sections

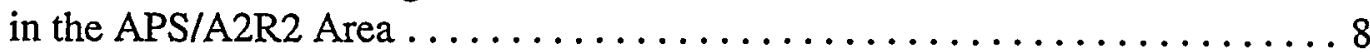

Figure 2.3 West-to-East Geologic Section APS-A, Illustrating the Stratigraphic and Depositional Relationships

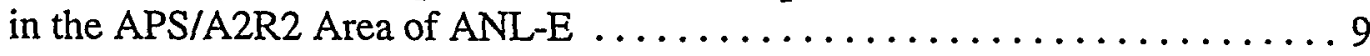

Figure 2.4 South-to-North Geologic Section APS-B, Ilustrating the Stratigraphic and Depositional Relationships in the APS/A2R2 Area of ANL-E . . . . . . . . . . . . . . . . . . . 10

Figure $4.1 \quad$ Location of 1980 Soil Samples Around CP-5 ................. 16

Figure $4.2 \quad$ CP-5 Soil Sample Locations $\ldots \ldots \ldots \ldots \ldots \ldots \ldots \ldots \ldots \ldots \ldots \ldots \ldots \ldots \ldots \ldots \ldots$

Figure $4.3 \quad$ Location of $41-\mathrm{ft}$ Core Bore in E-Wing $\ldots \ldots \ldots \ldots \ldots \ldots \ldots \ldots \ldots$

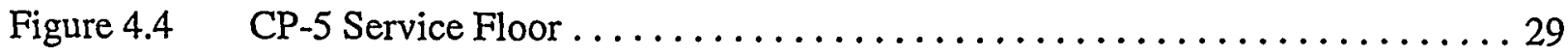

Figure $5.1 \quad$ RESRAD Family-Farm Pathways $\ldots \ldots \ldots \ldots \ldots \ldots \ldots \ldots \ldots \ldots \ldots \ldots$

Figure $6.1 \quad$ Family-Farm Scenario Dose as a Function of Time $\ldots \ldots \ldots \ldots \ldots$

Figure $7.1 \quad$ Family-Farm Dose Component Pathways $\ldots \ldots \ldots \ldots \ldots \ldots \ldots \ldots$

Figure 7.2 Concentration of Tritium in Well Water as a Function of Time ........ 37 
Figure 7.3 Sensitivity Analysis on Length Parallel to Aquifer Flow $\ldots \ldots \ldots \ldots . .38$

Figure 7.4 Sensitivity Analysis on Saturated Zone Hydraulic Conductivity . . . . . . . . 39

Figure 7.5 Sensitivity Analysis on Contaminated Zone Hydraulic Conductivity $\ldots . .40$

Figure 7.6 Sensitivity Analysis on Unsaturated Zone 1 Effective Porosity $\ldots \ldots \ldots 41$

Figure 7.7 Sensitivity Analysis on Saturated Zone Effective Porosity . . . . . . . . . . 42 


\section{LIST OF TABLES}

Table 3.1 Average Tritiated Water Content of Water and Fish

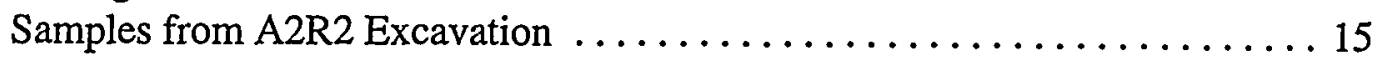

Table $4.1 \quad 1980$ CP-5 Soil Sample Results ........................ 17

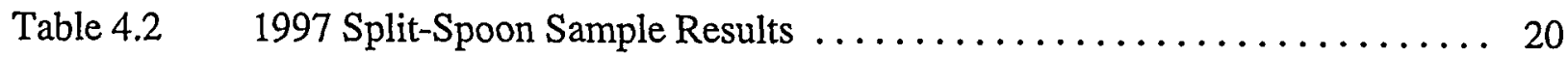

Table $4.3 \quad$ E-Wing Boring Split-Spoon Sample Results $\ldots \ldots \ldots \ldots \ldots \ldots \ldots \ldots$

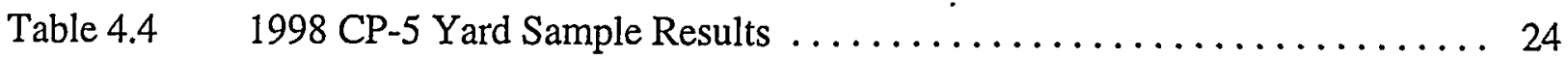

Table $4.5 \quad$ CP-5 Monitoring Well Specifications $\ldots \ldots \ldots \ldots \ldots \ldots \ldots \ldots \ldots$

Table 4.6 Tritium Concentrations in CP-5 Monitoring Wells ............. 25

Table 4.7 Tritium Concentration in Fuel Pool Floor Concrete ............. 27

Table $4.8 \quad$ Rod-Out Hole Sampling Results $\ldots \ldots \ldots \ldots \ldots \ldots \ldots \ldots \ldots$

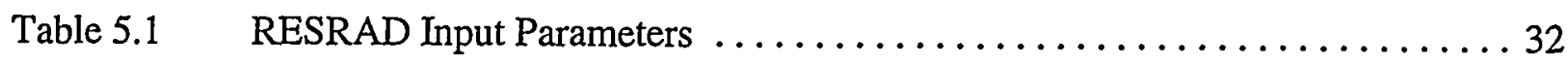

Table 6.1 Potential Radiological Impacts Estimate Summary .............. 34 


\subsection{INTRODUCTION}

\subsection{Background}

The Chicago Pile-Five (CP-5) reactor is an inactive research reactor located in the Building 330 complex in the southwest quadrant of the Argonne National Laboratory-East (ANL-E) site (Figure 1.1). The CP-5 reactor first achieved criticality in 1954 and was shut down in September 1979. By January 1980, all of the spent fuel and heavy water that could be drained from the cooling system were shipped to the Savannah River Site.

CP-5 operated at a thermal power of $1 \mathrm{MW}$ (million watt) from 1954 to 1960 and $5 \mathrm{MW}$ from 1960 to 1979. The purpose of the reactor was to produce neutrons for experimentation. Essentially all of the thermal energy produced by CP- 5 was dissipated to the atmosphere by cooling towers that were located at $330 \mathrm{H}$ and $330 \mathrm{G}$ in the CP-5 yard south of the reactor building (Figure 1.2). Initially, fuel was stored in below-grade storage holes. Wet-fuel storage was added after the reactor thermal power was increased to $5 \mathrm{MW}$. The spent fuel pool was located in E-Wing of the Building 330 complex, adjacent to the CP-5 yard.

In 1989, water was detected in the below-grade storage holes in the rod storage area (Figure 1.3). A shallow monitoring well (330011) was installed shortly after discovering the potential leakage into the storage holes to determine whether contamination was migrating from the building into the surrounding soil. Figure 1.4 presents the levels of tritium detected in the well since its installation. Tritium concentrations have never exceeded the $20 \mathrm{pCi} / \mathrm{ml}$ U.S. Environmental Protection Agency (EPA) drinking water limit for tritium. In 1993, extensive sampling of the CP-5 yard was performed. While radioactive contamination and some hazardous constituents were detected, the levels were low enough to indicate that no further action was necessary to release the yard for unrestricted use. Pending Illinois Environmental Protection Agency (IEPA) approval, the CP-5 yard could be removed from the list of Solid Waste Management Units (SWMU). The de-listing of the CP-5 yard as a SWMU was unsuccessful due to the level of hazardous constituents (antimony and chromium in soil and antimony and manganese in groundwater).

In June 1997, the deep groundwater monitoring well 330012D shown in Figure 1.2 was installed south of CP-5 to determine if any contaminants were migrating down to the Niagara Dolomite bedrock. Initial monitoring results from the deep dolomite well did not indicate that tritium had reached the groundwater; however, subsequent sampling results from November 1997 and March 1998 did indicate slightly elevated tritium levels in the dolomite groundwater. 

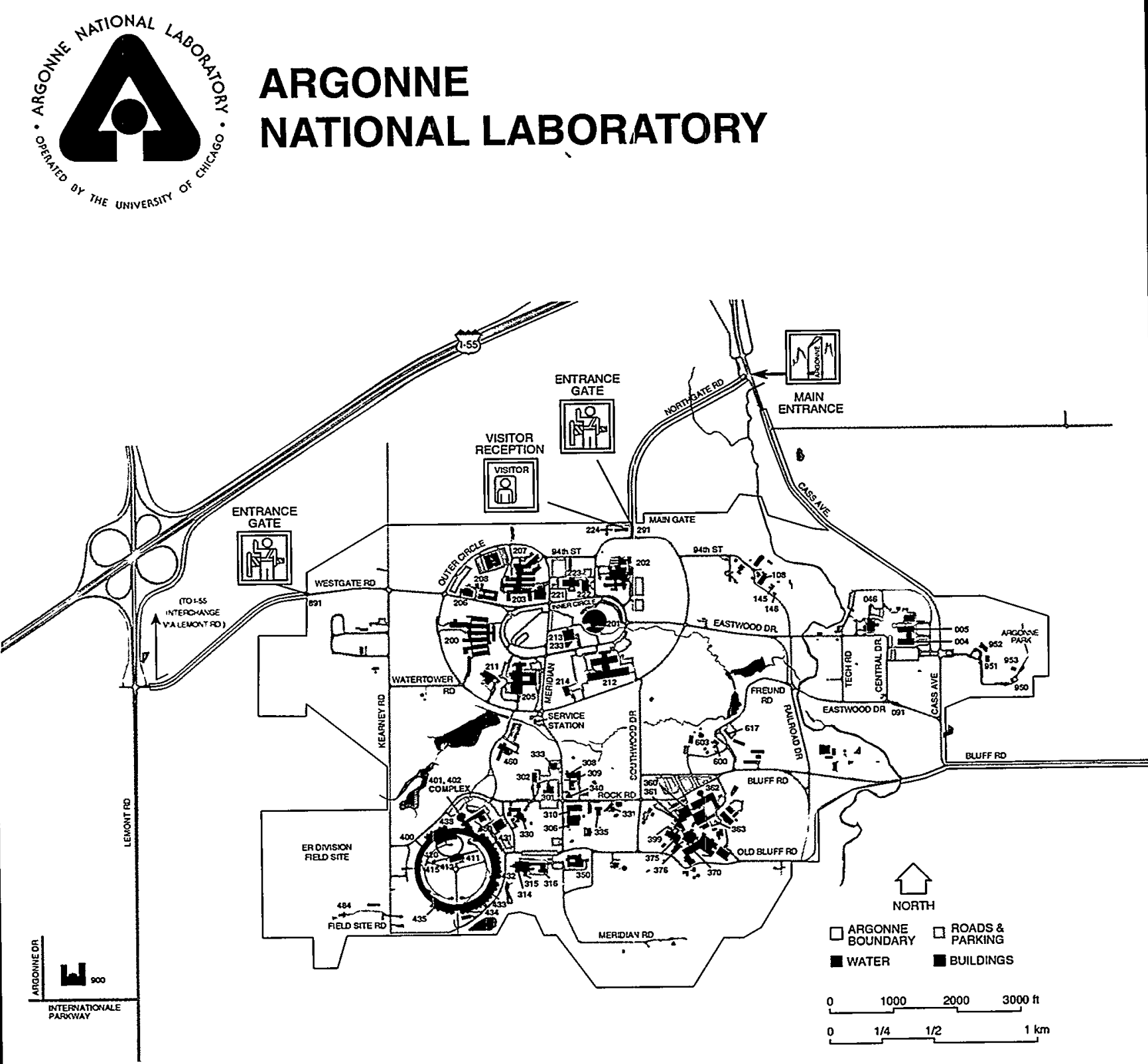

Figure 1.1 Map of Argonne National Laboratory-East 

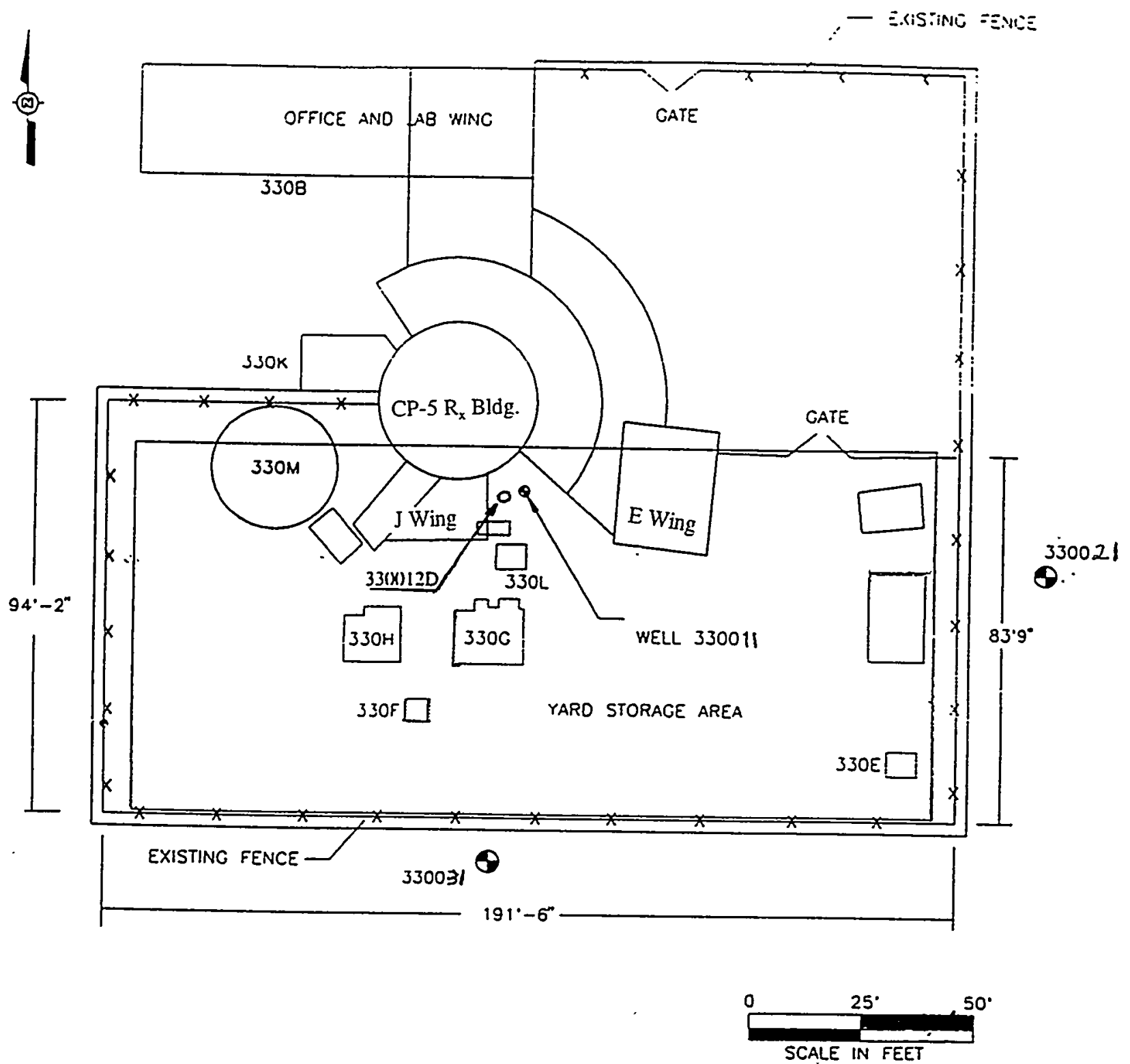

LEGENO:

- MONITORING WELl LOCATION

Figure 1.2 CP-5 Reactor Area and Monitoring Well Locations 


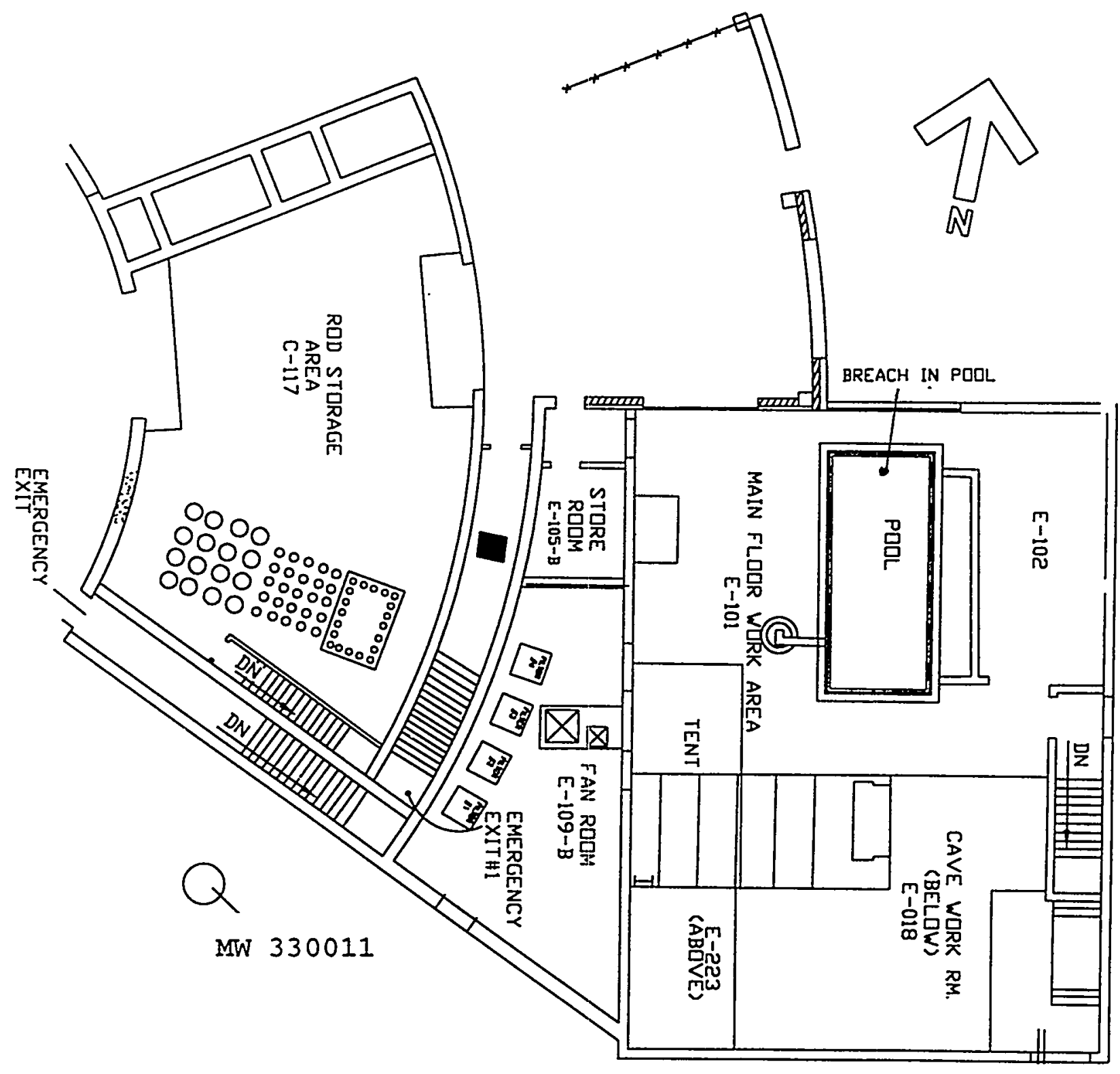

Figure 1.3 Location of Spent Fuel Pool in E-Wing 


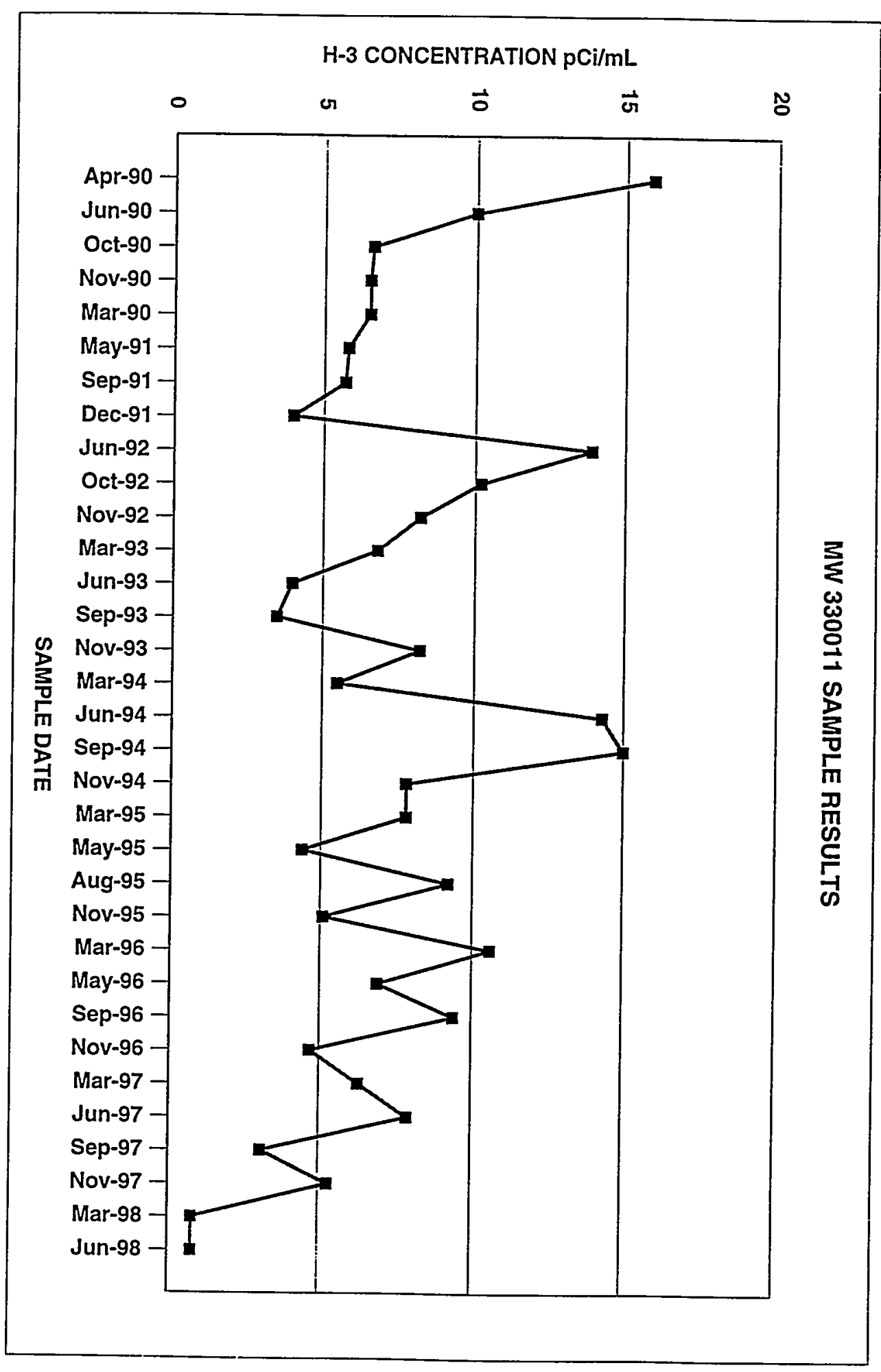

Figure 1.4 Shallow Well 330011 Groundwater Monitoring Results 
In November 1997, after removal and disposal of fuel pool water, a small, 1/8 in-diameter hole was discovered in the bottom of the spent fuel pool stainless steel liner (Figure 1.3). If the 3-ft concrete foundation of the pool had been breached, there may be a potential pathway to the soil surrounding Building 330. Consequently, additional core-bore sampling was performed to determine if the source of the tritium in CP-5 yard soil could be the fuel pool.

\subsection{Purpose and Scope of This Investigation}

The purpose of this investigation was to estimate the magnitude of potential radiological impacts from tritium-contaminated soil and groundwater at the CP-5 site and to determine whether remediation of tritium-contaminated soil is required for the restricted or unrestricted release of the CP-5 yard. This investigation consisted of a review of the CP-5 operating history, a radiological monitoring data review (soil, water, and miscellaneous sampling), and a pathway analysis/dose assessment using the RESidual RADioactive material guidelines (RESRAD) computer code, version 5.82. The results of this investigation are also intended to guide future surveillance, sampling, and surveying of outdoor areas encompassing the Building 330 complex for eventual restricted or unrestricted release.

\subsection{GEOLOGY/HYDROGEOLOGY OF THE CP-5 SITE}

\subsection{Geology}

The CP-5 yard area is generally flat with a ground elevation of approximately $745 \mathrm{ft}$ above mean sea level (AMSL). The yard overlies a 126-ft thick deposit of heterogeneous glacial till on top of dolomite bedrock on the eastern edge of the Advanced Photon Source (APS) area of the ANL-E site. The northern portion of this area is known as the Argonne Advanced Research Reactor $\left(A^{2} R^{2}\right)$ area, because it had been the proposed location for the $A^{2} R^{2}$ project before its cancellation. The location of the APS $/ A^{2} R^{2}$ area and the location of the geologic cross sections are shown in Figures 2.1 and 2.2. The west-to-east trending geologic section, APS-A, is shown in Figure 2.3. APS-B trends south to north, as shown in Figure 2.4. Appendix A contains the IEPA Well Completion Report and Field Boring Log for deep well 330012D (Figure 2.2) installed south of the CP-5 reactor building.

The upper layer (Wadsworth Formation) of glacial till has a relatively uniform composition across the ANL-E site and consists of silty clay, clay loam, and silty clay loam glacial deposits with lenses of sand, silt, and clay (Killey and Trask 1994). The thickness of the Wadsworth layer under CP-5 is approximately $65 \mathrm{ft}$ (Argonne 1997). Deposits of sand and gravel occur as discontinuous lenses throughout the glacial till of the Argonne site. The thin sand lenses occurring in the Wadsworth till of the APS $/ A^{2} R^{2}$ area are of limited hydrologic significance (Argonne 1998). 

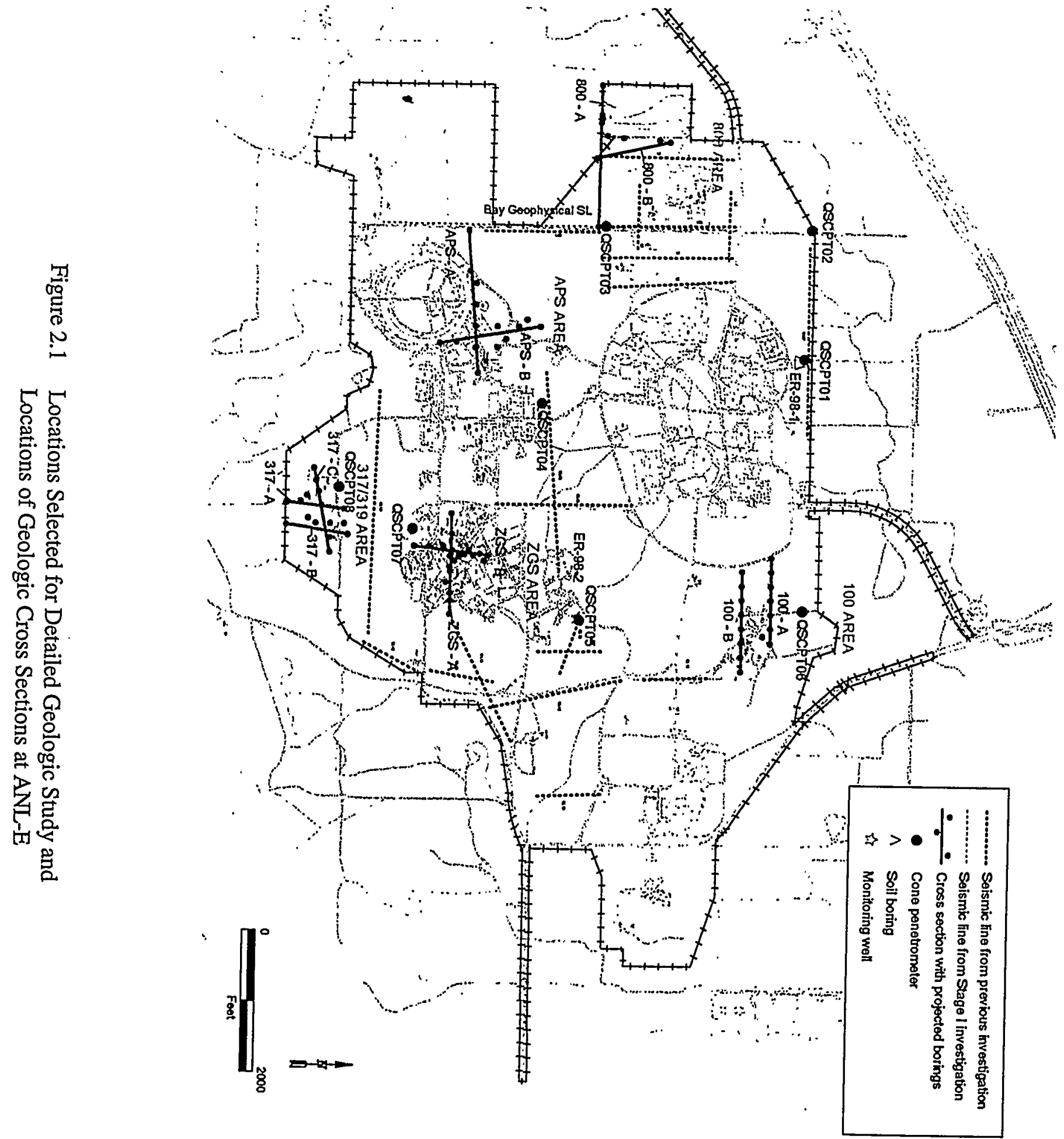


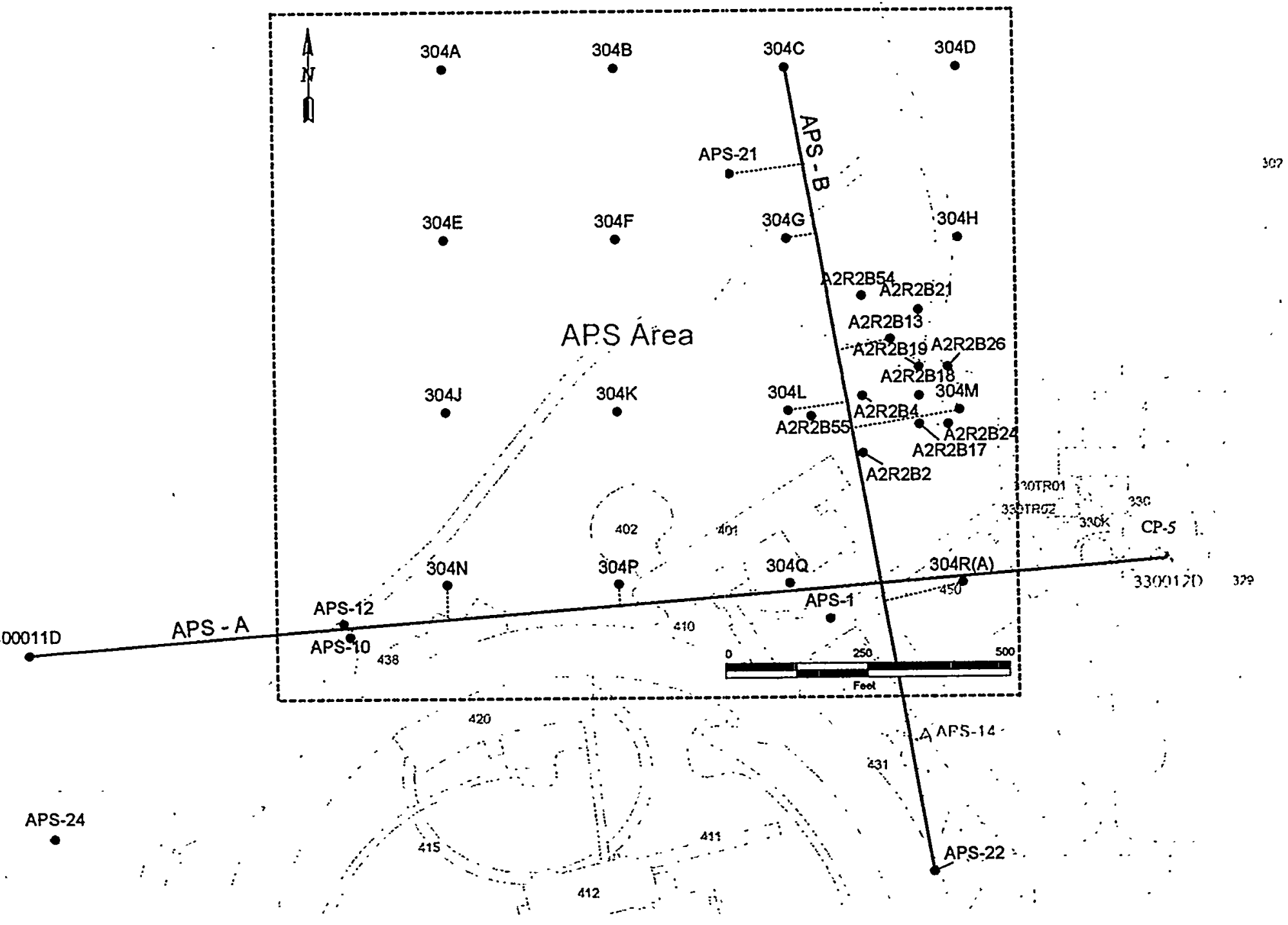

Figure 2.2 Locations Selected for Detailed Geologic Study and Locations of Geologic Cross Sections in the APS/ $/ \mathrm{A}^{2} \mathrm{R}^{2}$ Area 


\section{INVESTIGATION OF TRITIUM SOIL}

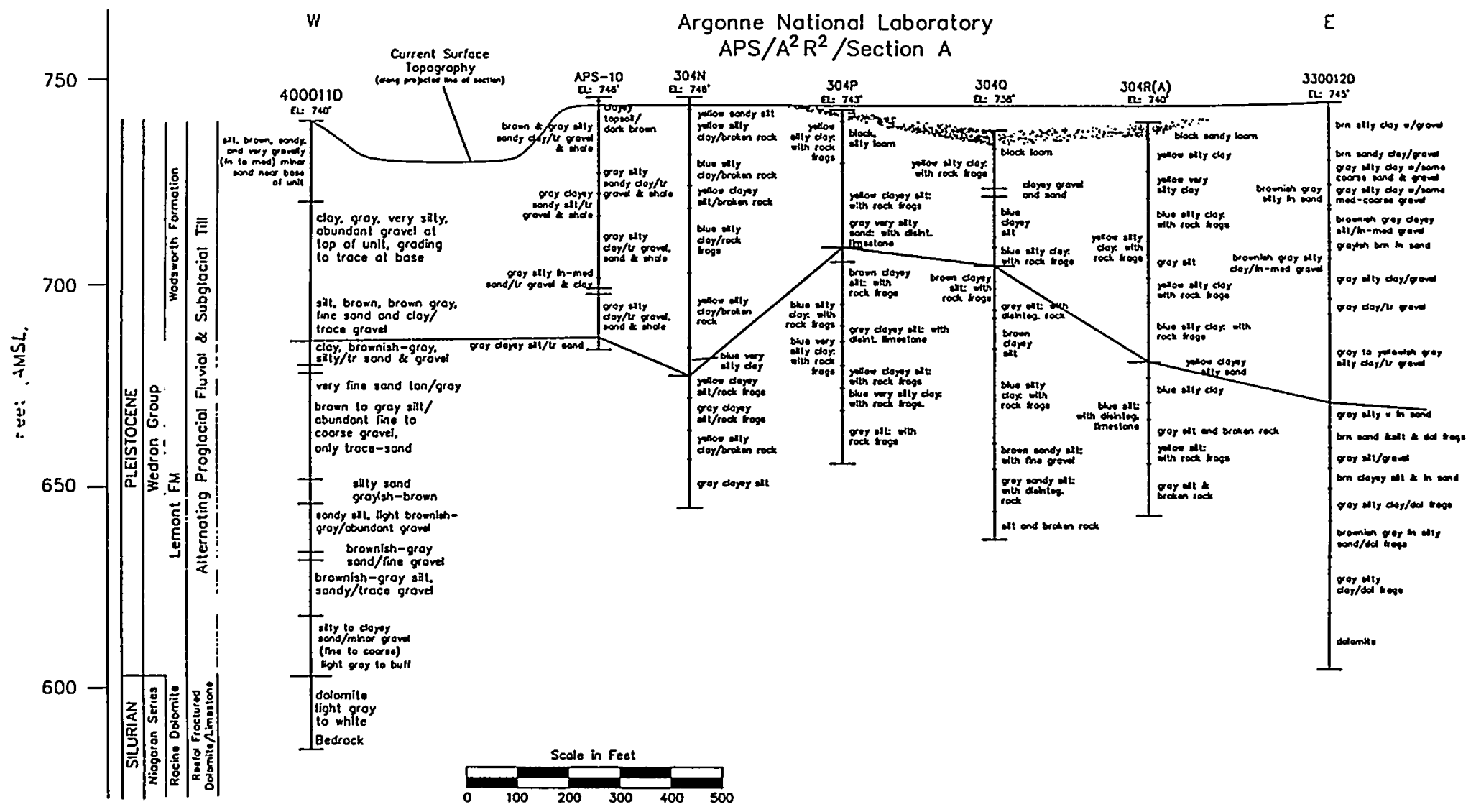

Figure 2.3 West-to-East Geologic Section APS-A, Mlustrating the Stratigraphic and Depositional Relationships in the APS/A ${ }^{2} R^{2}$ Area of ANL-E 


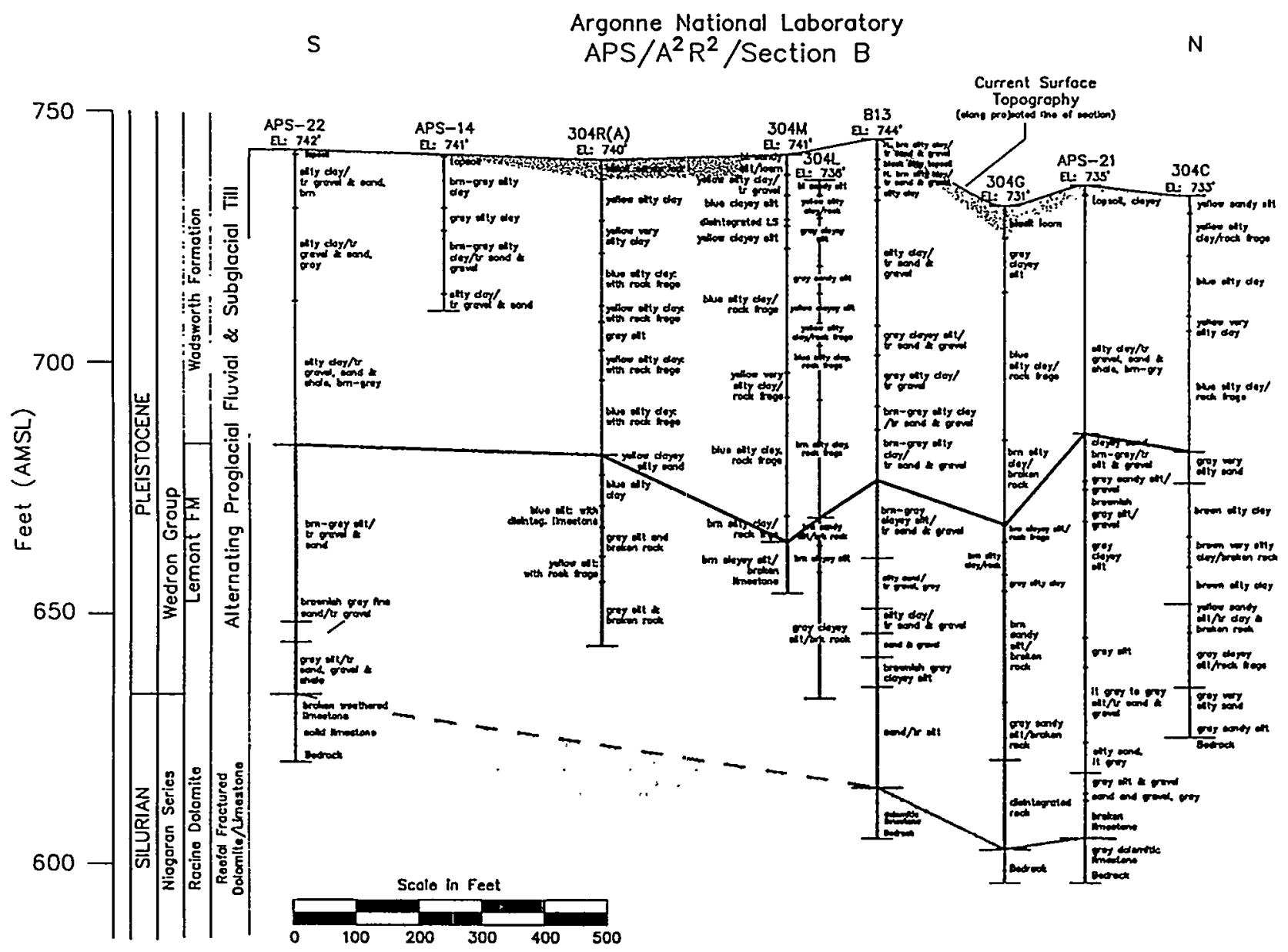

Figure 2.4 South-to-North Geologic Section APS-B, Mlustrating the Stratigraphic and Depositional Relationships in the APS/ $\mathrm{A}^{2} \mathrm{R}^{2}$ Area of ANL-E 
Shallow monitoring wells (monitoring zones ranging from 2 to $20 \mathrm{ft}$ in depth) installed south and east of the CP-5 complex and soil boring logs performed by IT Corporation in 1993, indicated that relatively porous, water-bearing regions of soil (sandy, gravelly, clay) do exist within the upper Wadsworth clay-till region around CP-5 (IT 1994). Lithologic and hydraulic-head relationships identified primarily in the $317 / 319 / \mathrm{ENE}$ and 800 Areas indicated that shallow groundwater may exist locally under unconfined to marginally confined conditions as relatively isolated perched accumulations within discontinuous deposits of coarser-grained materials above the dolomite water table at the ANL-E site (Argonne 1997). Appendix B contains the stratigraphic column and split-spoon core $\log$ for the shallow water well (330011) installed south of the CP-5 reactor building in 1989.

The underlying Lemont Formation beneath the Wadsworth layer consists of considerably more silt and less clay than the overlying Wadsworth layer. A study conducted by the Illinois State Geologic Survey (ISGS) at the APS site indicated that the Lemont drift, which consists of silty clay loam to silt loam, has an average fine-grained matrix (less than $2 \mathrm{~mm}$ ) of $16 \%$ sand, $64 \%$ silt, and $20 \%$ clay compared with the average of $16 \%$ sand, $45 \%$ silt, and $39 \%$ clay in the overlying Wadsworth till (Killey and Trask 1994). The thickness of the Lemont Formation under the CP-5 complex is approximately $60 \mathrm{ft}$ (Argonne 1997).

\subsection{Hydrogeology}

The downward velocity of water through the glacial till at ANL-E was determined by W. J. Drescher of the U.S. Geologic Survey (USGS) in 1952 to average $0.25 \mathrm{~cm} /$ day $(0.91 \mathrm{~m} / \mathrm{yr})$. More recent estimates of the downward velocity of water through the till were made in the vicinity of the 800 Area landfill (located in the northeast quadrant). They indicate a downward velocity of $6 \times 10^{-3} \mathrm{~cm} /$ day (Geraghty and Miller, 1995).

Available data indicate that the direction of groundwater movement within the dolomite bedrock aquifer under ANL-E is predominantly east (Argonne 1998). Groundwater within the dolomite aquifer originating in the western and central portions of ANL-E flows off-site both to the south and east, toward discharge areas along the Des Plaines River Valley (583 ft AMSL). The horizontal groundwater velocity calculated using a horizontal hydraulic conductivity of $4 \times 10^{-3} \mathrm{~cm} / \mathrm{sec}$ and an estimated fracture porosity of $10 \%$ is $1.9 \mathrm{~cm} /$ day, but channelized flow in fractures may be significantly higher (Geraghty and Miller, 1995). Recharge of the dolomite aquifer occurs via precipitation through the unconsolidated glacial sediments that cover the ANL-E site. Since no drinking water supplies are located between the CP-5 complex and the Des Plaines River (located south of CP-5), the potential for human consumption is low (Argonne 1998). 


\subsection{Surface Water}

Natural surface runoff from the ANL-E site, including CP-5, occurs primarily via a network of streams and ditches that are tributary to Sawmill Creek. The creek discharges into the Des Plaines River, located approximately 1.2 miles south of CP-5.

\subsection{POTENTIAL SOURCES OF TRITIUM IN CP-5 YARD SOIL}

Tritium (H-3) is a radioactive isotope of hydrogen with an atomic number of 1 and atomic weight of 3. It decays with a half-life of 12.35 years by emission of a low-energy beta particle (electron with a mean energy of $5.7 \mathrm{keV}$ ). Tritium is primarily an internal dose hazard. The low-energy beta emitted during the decay process from tritium is unable to penetrate the skin. In heavy water reactors like $\mathrm{CP}-5$, neutron activation of deuterium $(\mathrm{H}-2)$ is the main source of tritium. Tritium was normally released by CP- 5 both in the form of tritiated water vapor released by the CP- 5 stack and in the form of water that circulated in the CP-5 cooling system that may have leaked during off-normal conditions into the surrounding soil. Once tritiated water has entered the soil, its transport will involve the same processes and follow the same paths as other water. Tritiated water is carried by bulk flow with the liquid water in the soil. At the same time, there is mixing of water in the soil because the water is dispersed among the different pores in the soil as it is transported. Tritium concentration units in this report either specify tritium radioactivity per unit mass of dry soil from which the water and tritium have been removed for analysis or tritium radioactivity per unit of water volume that has been removed from soil or simply well water. There are several potential tritium sources that may have contributed to the tritium identified in soil samples and monitoring well samples around the CP-5 yard. Several documented incidents and hypothetical scenarios are discussed below.

\subsection{Tritium Releases From Primary to Secondary Cooling System}

A primary-to-secondary coolant leak through a small hole in the main heat exchanger of CP-5 occurred in 1964 (Argonne 1965). The leak allowed between 364 and $738 \mathrm{Ci}$ of tritiated water to enter the secondary cooling system. ${ }^{12,3}$ In 1971, another primary-to-secondary cooling system leak allowed between 40 to $80 \mathrm{Ci}$ to enter the secondary cooling system. ${ }^{4}$

\footnotetext{
${ }^{1}$ Memo, R. Ditch to R. Rose, "Heat Exchanger Leaks Discharging Tritium Contaminated Heavy Water to Cooling Towers", 2/16/98

${ }^{2}$ Reactor Operations Memo \#55 titled: "Failure and Repair of the Main Heat Exchanger of CP-5," September 2, 1964

${ }^{3}$ Data log "Tritium Concentration in CP-5 Heavy Water"

${ }^{4} \mathrm{CP}-5$ Operations Log Concerning Heat Exchanger Leak in 1971, Talboy, J.
} 


\subsection{Draining Secondary System Water to Footing Drains}

The service floor of CP-5 contains several iron rod-out holes (similar to manholes) joined by clay piping located under and around the outer circumference of the service floor approximately $14 \mathrm{ft}$ below grade. The piping leads to the laboratory sanitary drain system. The purpose of this circular ring of piping or drain-tile system under the service floor is to prevent shallow groundwater from damaging the building foundation. The system allowed groundwater to enter the clay pipe at loose or "leaky" connections between pipe segments, thereby draining the groundwater into the clay piping. It also provided a convenient route for the release of water from the secondary side of the main heat exchanger that had been located on the service floor.

\subsection{Secondary System Water Leakage to CP-5 Yard Soil}

\subsubsection{Tritiated Water Leaks From Cooling Tower Piping}

The CP-5 secondary cooling system water is believed to have been normally contaminated with low levels of tritium from small primary-to-secondary system leaks. On at least two documented occasions, as discussed in Section 3.1, large quantities of tritium entered the secondary cooling system water. Some tritiated water may have been released through a postulated leak in the secondary cooling system piping leading from the service floor of the CP-5 reactor building to the cooling towers located in the south yard. Based on an old photograph of the excavated secondary piping leading to the cooling towers, the piping was located approximately $12 \mathrm{ft}$ below grade, or $732 \mathrm{ft}$ AMSL, and contained at least two flanged pipe-segment connections.

\subsubsection{Tritiated Water Leaks From CP-5 Drain Tile System}

In February 1998, sludge and water samples were collected from the rod-out holes in the service floor of CP-5 (see Section 4.3.2). Based on the tritium levels found in the holes, it appears likely that $\mathrm{CP}-5$ operational personnel drained contaminated secondary coolant water to the drain tile system, causing a small fraction of the tritiated water to escape the pipe at the loose or "leaky" pipe connection points and thereby making a contribution to the tritium concentrations in CP-5 yard soil. These subsurface leaks would have occurred at approximately $14 \mathrm{ft}$ below grade or $731 \mathrm{ft}$ AMSL.

\subsubsection{Tritiated Water Releases to a Storm Drain}

In 1964, 3,000 gal of tritiated water were mistakenly sent directly to a storm drain located in the south end of the CP- 5 yard rather than to the laboratory drain for processing. ${ }^{5}$ The extent to which this release may have contributed to tritium in CP-5 yard soil is unknown.

${ }^{5}$ Memo, J. Aldana to R. Rose, "Possible Sources of Tritium Around Building 330", 3/3/98 
INVESTIGATION OF TRITIUM SOIL

\subsection{Fuel Pool Liner Hole Leakage}

In November 1997, a small, 1/8-in diameter hole was discovered in the spent fuel pool's liner (located in E-Wing) approximately $25 \mathrm{ft}$ below grade. Subsequent sampling of the concrete pool foundation and adjacent soil core bores did not indicate that the fuel pool had contributed to CP-5 yard tritium (see section 4.1.6).

\subsection{Water Identified in the Rod Storage Area Below-Grade Holes}

In 1989, water was detected in the below-grade storage holes in the rod storage area in Room C-117. Follow-up sampling and monitoring did not indicate that the rod storage area below-grade holes had contributed to CP-5 yard tritium.

\subsection{Airborne Tritium Fallout}

\subsubsection{Cooling Tower Evaporation}

Evaporation and subsequent fallout or rainout of tritium-contaminated secondary cooling system water as it flowed within the cooling towers during the operational life of CP-5 would have contributed to tritium identified in CP-5 yard soil.

\subsubsection{Ventilation System Stack}

The normal operation of CP-5 (1954-1979) released significant amounts of water vapor containing tritium (up to $3 \mathrm{Ci} /$ day and $1,000 \mathrm{Ci} / \mathrm{yr}$ ) from the main ventilation system stack located $56 \mathrm{ft}$ above the ground on the east side of the CP-5 Reactor Building. The water vapor emitted from the stack would have either condensed and fallen to the ground as precipitation or been brought to the ground by rain (rainout) and would have contributed significantly to tritium in CP-5 yard soil.

In 1967, an excavation was dug approximately $150 \mathrm{~m}$ northwest of CP-5 for the foundation of the proposed $A^{2} R^{2}$. The project was canceled, but the 40-m diameter, 13-m deep excavation eventually filled with water, creating a pond. Radiological monitoring of the water and fish that eventually populated the $A^{2} R^{2}$ pond began in 1973. The pond water monitoring results shown in Table 3.1 indicate that tritium emissions from CP-5 accumulated in the pond as a result of rainout. The tritium concentration in pond water increased until 1978 and then decreased as the tritium released from CP-5 decreased (Golchert et al. 1983). Based on the levels of tritium measured in the pond $150 \mathrm{~m}$ away, rainout of tritium near the point of exhaust from the east side of CP-5 would have significantly contributed to the tritium levels identified in CP-5 yard soil and water. 


\section{INVESTIGATION OF TRITIUM SOIL}

CONTAMINATION IN THE CP-5 YARD

Page 15 of 118

Table 3.1 Average Tritiated Water Content of Water and Fish Samples from $A^{2} R^{2}$ Excavation

\begin{tabular}{||c|c|c|c|c||}
\hline Year & $\begin{array}{c}\text { Number Of } \\
\text { Water Samples }\end{array}$ & $\begin{array}{c}\text { Tritium Concentration } \\
\text { in Water } \\
\text { (pCi/ml) }\end{array}$ & $\begin{array}{c}\text { Number of } \\
\text { Fish } \\
\text { Samples }\end{array}$ & $\begin{array}{c}\text { Tritium Concentration } \\
\text { in Fish Tissue Water } \\
\text { (pCi/ml) }\end{array}$ \\
\hline \hline 1973 & 2 & 8.1 & 1 & 6.0 \\
\hline 1974 & 3 & 6.8 & 3 & 5.9 \\
\hline 1975 & 3 & 9.1 & 1 & 8.8 \\
\hline 1976 & 2 & 11.1 & 2 & 8.9 \\
\hline 1978 & 1 & 11.4 & 1 & 11.0 \\
\hline 1979 & 1 & 8.7 & 1 & 9.0 \\
\hline 1980 & 1 & 8.4 & 2 & 7.8 \\
\hline 1981 & 4 & 4.3 & - & - \\
\hline Jan.-June 1982 & 6 & 3.7 & - & - \\
\hline July-Dec. 1982 & 5 & 2.1 & - & - \\
\hline \hline
\end{tabular}

\subsection{CP-5 RADIOLOGICAL MONITORING}

\subsection{Soil Sampling}

\subsubsection{CP-5 Area Soil Sampling Results}

In June 1980, twelve surface soil samples were collected from depth intervals of $0-2$ in and $2-6$ in below the surface at eight locations around the CP-5 reactor building. Each sample was analyzed by ANL-E Environment, Safety and Health (ESH) personnel using gamma-ray spectrometry. Soil moisture tritium concentrations were determined by liquid scintillation. The analytical results are presented in Table 4.1. ${ }^{6}$ Tritium levels measured in surface soil moisture ranged from 0.3 to $3.9 \mathrm{pCi} / \mathrm{g}$ with the highest tritium levels occurring at sample location B (Figure 4.1) located closest to the CP-5 ventilation system stack on the east side of the CP-5 reactor building roof. Cs- 137 and Co-60 soil concentrations are within the range normally present in environmental samples. 


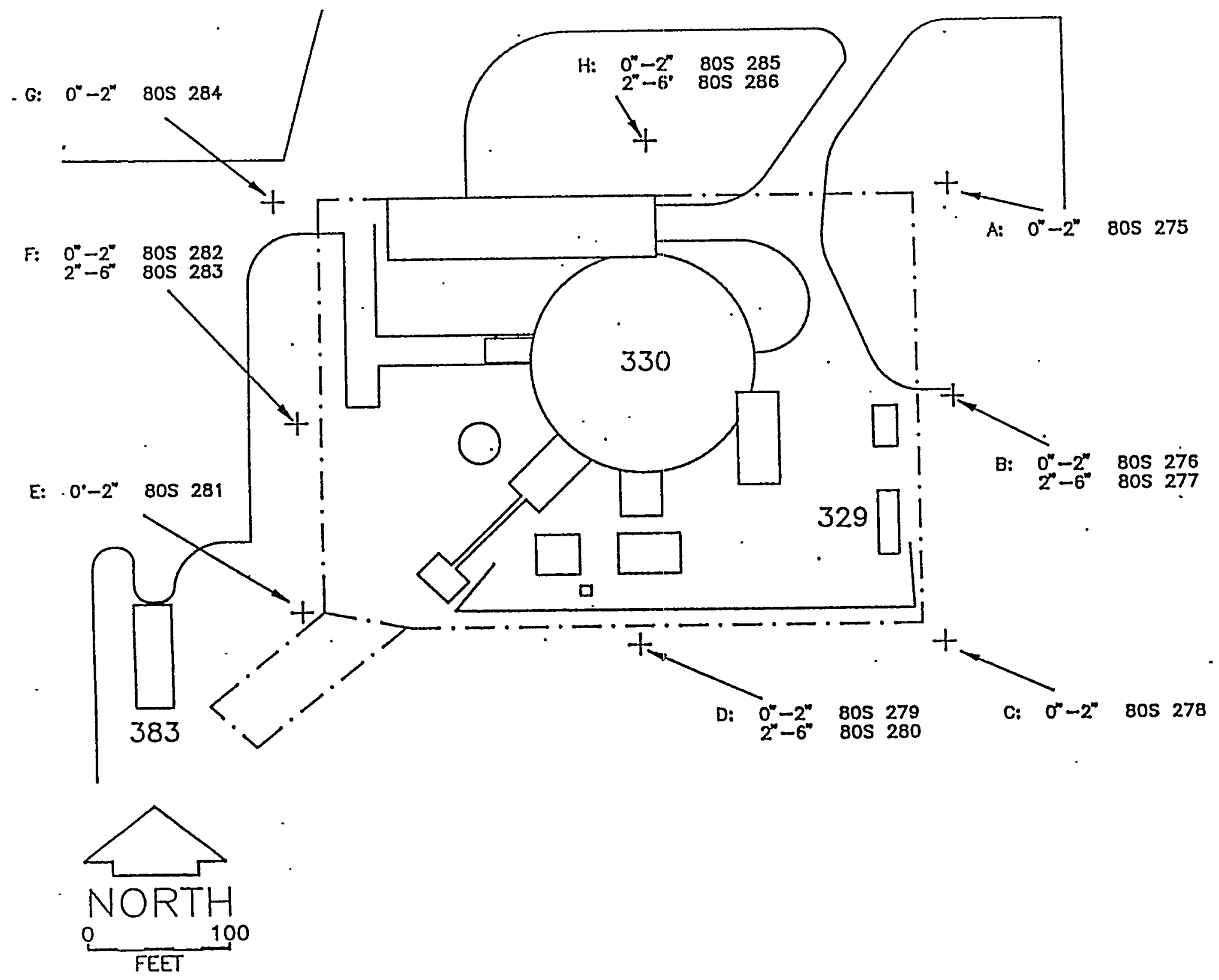

Figure 4.1 Location of 1980 Soil Samples Around CP-5 
INVESTIGATION OF TRITIUM SOIL

Table 4.1 1980 CP-5 Soil Sample Results

\begin{tabular}{||c|c|c|c|c|c||}
\hline $\begin{array}{c}\text { Sample } \\
\text { Number }\end{array}$ & $\begin{array}{c}\text { Location } \\
\text { in Figure 4.1 }\end{array}$ & $\begin{array}{c}\text { Sampling Depth } \\
\text { Interval (in) }\end{array}$ & $\begin{array}{c}\text { H-3 } \\
\text { (pCi/g) }\end{array}$ & $\begin{array}{c}\text { Co-60 } \\
\text { (pCi/g) }\end{array}$ & $\begin{array}{c}\text { Cs-137 } \\
\text { (pCi/g) }\end{array}$ \\
\hline \hline $80 S 275$ & A & $0-2$ & $0.48 \pm 0.04$ & $<0.1$ & $0.3 \pm 0.1$ \\
\hline $80 S 276$ & B & $0-2$ & $3.90 \pm 0.07$ & $<0.1$ & $1.2 \pm 0.1$ \\
\hline $80 S 277$ & B & $2-6$ & $2.96 \pm 0.05$ & $<0.1$ & $0.4 \pm 0.1$ \\
\hline $80 S 278$ & C & $0-2$ & $0.31 \pm 0.05$ & $<0.1$ & $1.1 \pm 0.1$ \\
\hline 80 S279 & D & $0-2$ & $0.51 \pm 0.05$ & $0.1 \pm 0.1$ & $1.3 \pm 0.1$ \\
\hline $80 S 280$ & D & $2-6$ & $0.46 \pm 0.03$ & $<0.1$ & $0.3 \pm 0.1$ \\
\hline $80 S 281$ & E & $0-2$ & $0.42 \pm 0.05$ & $<0.1$ & $1.2 \pm 0.1$ \\
\hline $80 S 282$ & F & $0-2$ & $0.56 \pm 0.05$ & $<0.1$ & $1.3 \pm 0.1$ \\
\hline $80 S 283$ & F & $2-6$ & $0.46 \pm 0.04$ & $<0.1$ & $0.9 \pm 0.1$ \\
\hline $80 S 284$ & G & $0-2$ & $0.93 \pm 0.05$ & $<0.1$ & $0.7 \pm 0.1$ \\
\hline $80 S 285$ & H & $0-2$ & $0.30 \pm 0.04$ & $<0.1$ & $0.4 \pm 0.1$ \\
\hline $80 S 286$ & H & $2-6$ & $0.31 \pm 0.03$ & $<0.1$ & $0.1 \pm 0.1$ \\
\hline
\end{tabular}

\subsubsection{20-ft Soil Core Sampling Results}

In August 1989, a shallow well (330011) was installed in a relatively porous, saturated soil region approximately $20 \mathrm{ft}$ south of the CP-5 reactor building and $8 \mathrm{ft}$ from E-Wing (Figure 1.3) after tritiated water was identified in the rod storage area below-grade holes. Core bore sampling was performed at 2 -ft intervals from the surface to a $20-\mathrm{ft}$ depth during well installation. Tritium soil concentration measurements performed by ESH ranged from 0.013 to $2.9 \mathrm{pCi} / \mathrm{g}$ with the highest level occurring in the 14-16-ft below-grade depth interval. Soil water content ranged from 10.3\% to $15.3 \%$, averaging $12.85 \%$ (see Appendix C). This water content is in good agreement with the mean water content (15.9\%) of glacial till measured at the APS site (STS 1990) and the water content of glacial till (10\% to 20\%) cited in Fetter 1980.

\footnotetext{
$11 / 16 / 89$

7Memo with Attachments, N. Golchert to R. Wynveen, "Analysis of CP-5 Monitoring Well Soil Cores",
} 


\subsubsection{IT Corporation CP-5 Yard Characterization}

In 1993, IT Corporation performed a radiological and hazardous material characterization of the CP-5 yard to determine whether the storage in the yard of equipment and lead shielding had resulted in contamination of the soil from radioactivity or hazardous material. A total of 21 soil borings were drilled at locations SB01 through SB21, as shown in Figure 4.2. At each location, one sample was obtained from the $0.5-1.5$-ft interval using a stainless steel hand auger. Continuous split-spoon samples were collected in all borings from $2 \mathrm{ft}$ to total depth (between 4 and $14 \mathrm{ft}$ deep). IT Laboratory results for the tritium levels obtained from soil moisture by the cryogenic distillation method are provided in Appendix C. Assuming that the samples had a 13\% water content, typical of CP-5 yard soils, tritium concentrations in surface soils $(0.5-1.5 \mathrm{ft})$ and subsurface soils $(4-14 \mathrm{ft}$ ) ranged from $<0.03$ to $2.8 \mathrm{pCi} / \mathrm{g}$ and $<0.05$ to $18.5 \mathrm{pCi} / \mathrm{g}$, respectively. The highest tritium levels were detected approximately $40 \mathrm{ft}$ south and $40 \mathrm{ft}$ east of the CP-5 reactor building within an area of approximately $150 \mathrm{~m}^{2}$, encompassing samples SB03, SB04, SB05, and SB13 in the 8-10-ft deep sampling interval. The average subsurface ( $8-10-\mathrm{ft}$ deep) tritium level at these locations is $10.4 \mathrm{pCi} / \mathrm{g}$, assuming a soil water content of $13 \%$.

The IT Laboratory analytical results (Appendix D) indicated that concentrations of naturally occurring radionuclides (K-40, Ra-226, Ra-228, and U-238) were within the range normally present in environmental samples. One surface sample, however, contained $8.6 \mathrm{pCi} / \mathrm{g}$ of Cs-137, approximately eight times the concentration of Cs-137 typically present in environmental samples from fallout. IT also identified Co-57, Co-60 and Eu-152 in several samples that were collected from $0.5-1.5 \mathrm{ft}$ deep. All of these radionuclides were present in levels of less than $2 \mathrm{pCi} / \mathrm{g}$ and were not included in this analysis. The focus of this analysis was tritium due to its mobility in the environment and prevalence in soils around the CP-5 yard.

\subsubsection{Dolomite Well Installation}

In June 1997, a deep monitoring well (330012D) was installed approximately $10 \mathrm{ft}$ west of shallow monitoring well 330011 (Figure 1.2) to monitor the tritium concentration in the dolomite groundwater. During well construction, an attempt was made to save selected soil cores for tritium analysis. No samples were collected between the ground surface and $50 \mathrm{ft}$ below grade. Only four samples collected between 50 to $125 \mathrm{ft}$ yielded sufficient water content for tritium analysis. Of these four samples, two contained soil water tritium concentrations $<0.1 \mathrm{pCi} / \mathrm{ml}$. Samples collected from the 50-52-ft deep and $103-105-\mathrm{ft}$ deep intervals contained soil water tritium concentrations of $0.41 \mathrm{pCi} / \mathrm{ml}$ and $0.54 \mathrm{pCi} / \mathrm{ml}$, respectively. ${ }^{8}$ These low tritium concentrations reflect the low permeability of the glacial till underlying the CP-5 yard. Assuming a moisture content of $13 \%$, the measured soil water concentrations of $0.41 \mathrm{pCi} / \mathrm{ml}$ and $0.54 \mathrm{pCi} / \mathrm{ml}$ correspond to tritium soil concentrations of only 0.05 and $0.07 \mathrm{pCi} / \mathrm{g}$, respectively.

\footnotetext{
${ }^{8}$ Memo, N. Golchert to R. Coley, "Tritium Concentrations in CP-5 Soil Cores", 12/04/97
} 


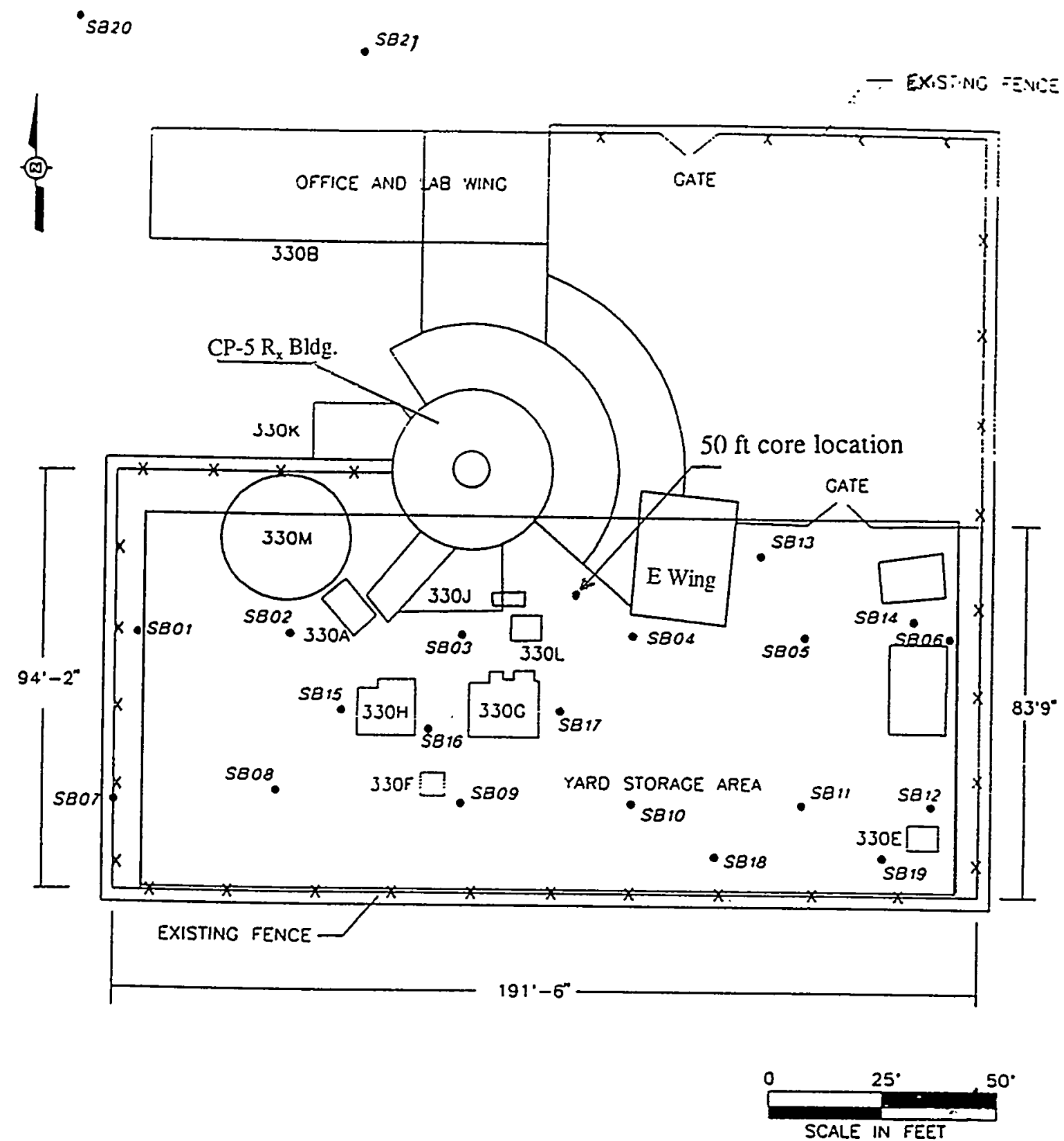

SBOB • SOIL SAMPLING LOCATION

Figure 4.2 CP-5 Soil Sample Locations 


\subsubsection{50-ft Deep Split-Spoon Sampling}

In December 1997, a 50-ft deep core boring was made at a location approximately $10 \mathrm{ft}$ south of shallow monitoring well 330011 and adjacent to E-Wing (Figure 4.2) to determine whether a hole in the stainless steel liner of the fuel pool floor had contributed to tritium identified in CP- 5 yard soil (see section 4.3.1). Split-spoon samples were obtained from $10-52.5 \mathrm{ft}$ deep at $1.5 \mathrm{ft}$ intervals. Table 4.2 contains the results of samples selected for tritium analysis by the ANL-E Analytical Chemistry Laboratory (ACL). Soil concentrations ranged from $<0.04$ to $14.4 \mathrm{pCi} / \mathrm{g}$ with concentrations reaching a maximum in the $20-21.5$-ft deep interval. Beyond $21.5 \mathrm{ft}$ deep, soil sample tritium concentrations declined with sample depth and showed no indication of tritium from the adjacent fuel pool concrete foundation located approximately $27 \mathrm{ft}$ below grade. ${ }^{9}$ The tritium concentration in the sample from the $14-15.5-\mathrm{ft}$ below grade sampling interval $(11.5 \mathrm{pCi} / \mathrm{g})$ was consistent with the results obtained during the 1993 IT sampling at locations SB03, SB04, and SB05 in the $8-10-\mathrm{ft}$ below grade sample interval.

Table 4.2 1997 Split-Spoon Sample Results

\begin{tabular}{|c|c|c|c|c||}
\hline Sample ID & Depth (ft) & H-3 (pCi/ml) & H-3 (pCi/g) & \% Moisture \\
\hline \hline 03 & $14-15.5$ & $91.0 \pm 2.0$ & $11.5 \pm 0.2$ & 12.6 \\
\hline 03 (Dup) & $14-15.5$ & $88.4 \pm 1.8$ & $11.1 \pm 0.2$ & $\cdots$ \\
\hline 06 & $20-21.5$ & $109 \pm 2$ & $14.4 \pm 0.2$ & 13.3 \\
\hline 07 & $22-23.5$ & $52.3 \pm 0.9$ & $6.8 \pm 0.1$ & 12.9 \\
\hline 08 & $24-25.5$ & $45.3 \pm 0.7$ & $5.7 \pm 0.1$ & 12.6 \\
\hline 11 & $30-31.5$ & $39.8 \pm 0.7$ & $5.6 \pm 0.1$ & 14.1 \\
\hline 15 & $39-40.5$ & $5.5 \pm 0.2$ & $0.74 \pm 0.03$ & 13.5 \\
\hline 20 & $51-52.5$ & $<0.33$ & $<0.04$ & 12.6 \\
\hline
\end{tabular}

${ }^{9}$ ANL Analytical Chemistry Laboratory "Report of Analytical Results", Sample Nos. 98-2027-01 thru 06, 


\subsubsection{Split-Spoon Sampling Adjacent to Fuel Pool}

In February 1998, split-spoon samples were obtained from a 41-ft-deep soil boring made through the floor of a room adjacent to the fuel pool in E Wing to determine whether the fuel pool was the source of tritium in CP-5 yard soil (Figure 4.3). Most of the samples were analyzed by Paragon Analytics, but some were "split" with the ACL. Note that the samples were not "split" in accordance with the technical meaning of "split sample." The split-spoon samples were simply divided with the upper portion going to Paragon and the lower portion going to the ACL. Other samples were analyzed only by the ACL. The Paragon Lab soil moisture tritium results from each 2-ft sampling interval from $13-41-\mathrm{ft}$ deep ranged from $0.1 \mathrm{pCi} / \mathrm{g}$ to $42.3 \mathrm{pCi} / \mathrm{g}^{10}$ (Table 4.3 ). The highest tritium concentration reported by Paragon ( $42.3 \mathrm{pCi} / \mathrm{g}$ ) was obtained from the $13-15-\mathrm{ft}$ deep sampling interval. This result is somewhat anomalous, because the other portion of sample, which was analyzed by ACL, yielded only $3.52 \mathrm{pCi} / \mathrm{g}$ tritium. ${ }^{11}$ Excluding the $42.3 \mathrm{pCi} / \mathrm{g}$ anomalous sample result, the range of concentrations obtained from the entire core was 0.1 to $3.8 \mathrm{pCi} / \mathrm{g}$ with an average of $1.7 \mathrm{pCi} / \mathrm{g}$. Sample concentrations generally showed a decline with sample depth beyond $15 \mathrm{ft}$ deep and showed no indication of tritium from the adjacent fuel pool floor located approximately $27 \mathrm{ft}$ below grade.

Assuming that the Paragon Laboratory sample result of $42.3 \mathrm{pCi} / \mathrm{g}$ at the $13-15$-ft interval is correct, the mean concentration in the $41-\mathrm{ft}$ core is $4.73 \mathrm{pCi} / \mathrm{g}$. A high tritium concentration (42.3 pCi/g) adjacent to a low concentration $(3.52 \mathrm{pCi} / \mathrm{g})$ would be indicative of a highly impermeable, retarding layer within the $13-15$-ft interval (between the Paragon sample and ACL sample) beneath the E-Wing and/or CP-5 Complex. No construction drawings indicated that such a man-made layer existed, but the existence of such a layer composed of engineered fill cannot be ruled out.

\subsubsection{CP-5 Yard Sampling}

In March 1998, soil samples were obtained at various distances from the CP-5 reactor building at various depths in the approximate location of the secondary system piping that led to the valve pit (330L in Figure 4.2) and cooling towers (330G and 330H in Figure 4.2) south of the CP-5 reactor building prior to the dismantlement of the cooling system in 1979. The soil tritium concentrations reported by Paragon Lab are presented below in Table 4.4. Tritium concentrations ranged from 0.79 to $8.8 \mathrm{pCi} / \mathrm{g}^{12}$ with the highest sample result obtained $42 \mathrm{ft}$ south of the CP-5 reactor building at the 14-16-ft below grade depth interval. Tritium concentrations generally increased with distance

\footnotetext{
${ }^{10}$ Paragon Analytics, Inc., "Tritium Analysis Results Summary", PAI ID Nos. 98-02-210-09 through -19, $3 / 3 / 98$

${ }^{11}$ ANL Analytical Chemistry Laboratory, "Report of Analytical Results" Sample Nos. 98-8135-01A through $01 \mathrm{C}, 02 ; 98-8139-01$ and -02
}

${ }^{12}$ Paragon Analytics Inc., "Tritium Analysis Results Summary", PAI ID Nos. 98-02-210-09 through -19, 


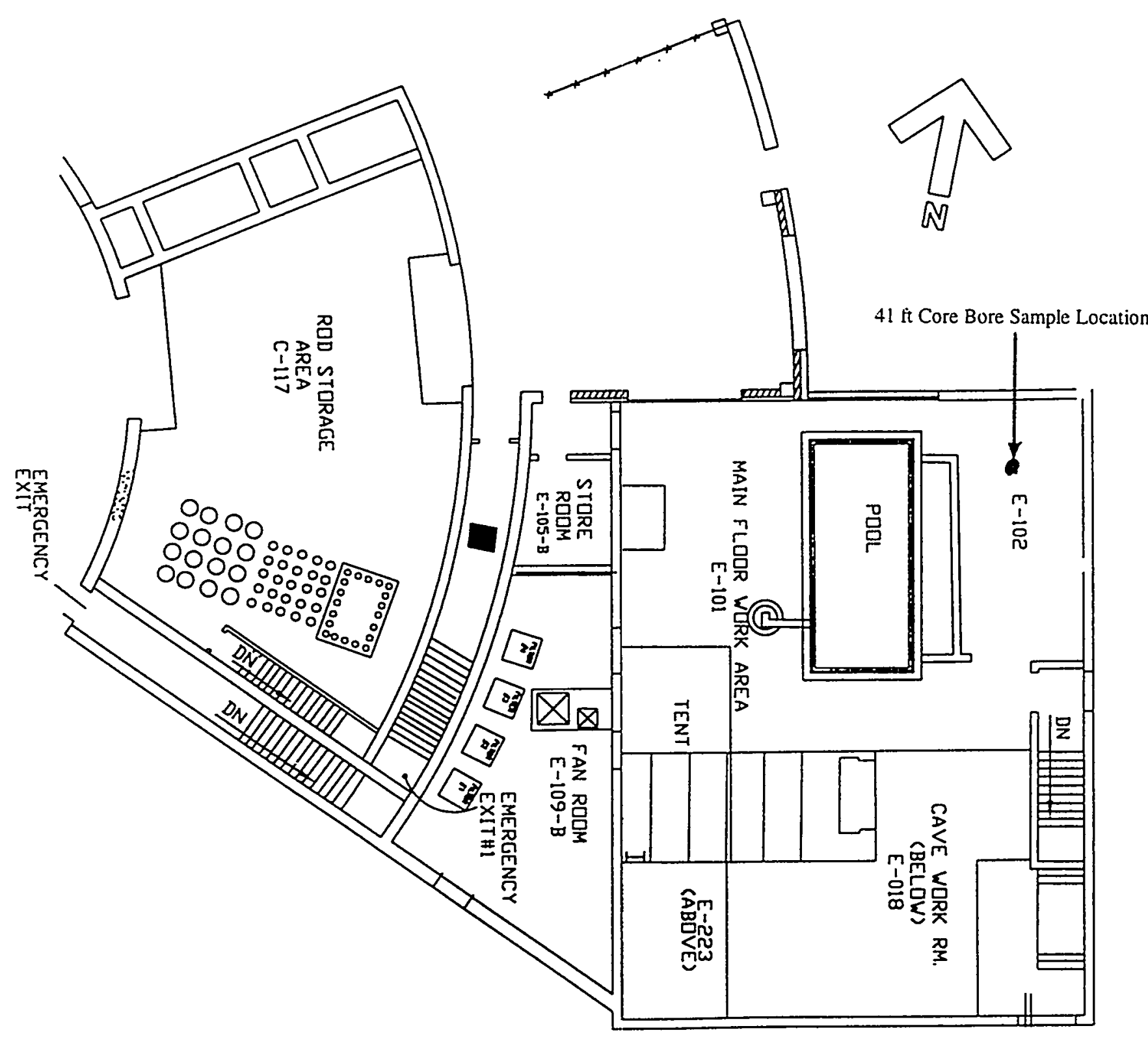

Figure 4.3 Location of 41-ft Core Bore in E-Wing 
Table 4.3 E-Wing Boring Split-Spoon Sample Results

\begin{tabular}{|c|c|c|c|c|}
\hline Sample $\mathrm{DD}$ & $\begin{array}{c}\text { Depth Interval } \\
(\mathrm{ft})\end{array}$ & $\begin{array}{c}\text { Paragon Lab H-3 } \\
(\mathrm{pCi} / \mathrm{g})\end{array}$ & $\begin{array}{l}\text { ANL-E ACL H-3 } \\
(\mathrm{pCi} / \mathrm{g})\end{array}$ & \% Moisture \\
\hline FP01 09-11 & $9-11$ & - & $3.8 \pm 0.1$ & 2.9 \\
\hline FP01 11-13 & $11-13$ & --.--..-- & $1.3 \pm 0.1$ & 1.3 \\
\hline FP01 13-15 & $13-15$ & $42.3 \pm 5.5$ & $3.52 \pm 0.08$ & $14.9 / 12.0$ \\
\hline FP01 15-17 & $15-17$ & $3.73 \pm 0.49$ & -.------. & 14.1 \\
\hline FP01 17-19 & $17-19$ & $2.42 \pm 0.32$ & - & 13.8 \\
\hline FP01 19-21 & $19-21$ & $2.69 \pm 0.36$ & - & 11.7 \\
\hline FP01 21-23 & $21-23$ & $1.26 \pm 0.17$ & (- & 12.5 \\
\hline FP01 23-25 & $23-25$ & $2.24 \pm 0.3$ & $1.15 \pm 0.05$ & $18.4 / 15.7$ \\
\hline FP01 25-27 & $25-27$ & $0.73 \pm 0.1$ & - & 11.0 \\
\hline FP01 33-35 & $33-35$ & $0.19 \pm 0.03$ & -...-.-.-- & 6.6 \\
\hline FP01 35-37 & $35-37$ & $0.55 \pm 0.08$ & - & 16 \\
\hline FP01 37-39 & $37-39$ & $0.18 \pm 0.04$ & -.-------- & 13.3 \\
\hline FP01 39-41 & $39-41$ & $0.1 \pm 0.04$ & $<0.05$ & $13.8 / 11.5$ \\
\hline
\end{tabular}

from the CP-5 reactor building and reached their highest levels in the same vicinity as the $1993 \mathrm{IT}$ SB03 sample location (Figure 4.2), suggesting that leaks in piping associated with the cooling towers may have significantly contributed to the tritium in the CP-5 yard soil. Paragon also performed gamma spectroscopy and Sr-90 analysis on each soil sample. All of the sample Sr-90 results were $<0.67 \mathrm{pCi} / \mathrm{g} .{ }^{13}$ Gamma-ray emitting radionuclides identified were naturally occurring decay chain progeny or fallout radionuclides in their typical environmental concentrations.

${ }^{13}$ Paragon Analytics Inc., "Sr-90 Analysis Results Summary" \& "Gamma Spec Results" PAI ID Nos. 9802-210-01 thru $-08,3 / 19 / 98$ 
INVESTIGATION OF TRITIUM SOIL

Table 4.4 1998 CP-5 Yard Sample Results

\begin{tabular}{|c|c|c|c|c|c|}
\hline Sample ID & $\begin{array}{c}\text { Depth Interval } \\
(\mathbf{f t})\end{array}$ & $\begin{array}{c}\text { Distance from } \\
\mathrm{R}_{\mathrm{X}} \text { Bldg. (ft) } \\
\end{array}$ & $\begin{array}{c}\text { Paragon H-3 } \\
(\mathrm{pCi} / \mathrm{g})\end{array}$ & $\begin{array}{c}\text { ANL-E ACL } \\
\mathrm{H}-3(\mathrm{pCi} / \mathrm{g})\end{array}$ & $\%$ Moisture \\
\hline YA1 10-12 & $10-12$ & 2.7 & $1.3 \pm 0.18$ & -------- & 19.6 \\
\hline YA1 12-14 & $12-14$ & 2.7 & $0.82 \pm 0.11$ & $0.7 \pm 0.03$ & $12 / 11.5$ \\
\hline YA2 11-13 & $11-13$ & 12 & $0.79 \pm 0.11$ & -..--..- & 12 \\
\hline YA2 13-15 & $13-15$ & 12 & $0.89 \pm 0.12$ & -.-.... & 16.9 \\
\hline YA3 12-14 & $12-14$ & 25 & $1.27 \pm 0.17$ & ……- & 10.7 \\
\hline YA3 14-16 & $14-16$ & 25 & $2.14 \pm 0.28$ & ------- & 12.9 \\
\hline YA4 12-14 & $12-14$ & 42 & $3.82 \pm 0.50$ & ---.-. & 11.9 \\
\hline YA4 14-16 & $14-16$ & 42 & $8.8 \pm 1.2$ & -.-.-.-- & 13.2 \\
\hline
\end{tabular}

\subsection{CP-5 Yard Area Water Sampling}

\subsubsection{Shallow Groundwater Monitoring}

In addition to the exploratory well installed in 1989 south of CP-5, two downgradient, shallow groundwater monitoring wells were installed as part of the 1993 IT Corporation CP-5 yard characterization. Monitoring well 330021 is located on the east side of the CP-5 yard, and monitoring well 330031 is located on the south end of the CP-5 yard (Figure 1.2). Monitoring well specifications from the annual ANL-E Site Environmental Reports are shown in Table 4.5. A fourth upgradient monitoring well was to be located on the north side of the CP-5 complex; however, the drilling of two separate boreholes, SB20 to $32 \mathrm{ft}$ deep and SB21 to $24 \mathrm{ft}$ deep (Figure 4.2), resulted in no water yields.

Sampling of the CP-5 monitoring wells is performed quarterly. The ESH tritium sampling results are published annually in the ANL-E Site Environmental Report and are summarized in Table 4.6. The highest tritium concentrations are associated with shallow groundwater monitoring well 330011 installed in 1989 , where tritium concentrations ranged from $15.9 \mathrm{pCi} / \mathrm{ml}$ to $0.8 \mathrm{pCi} / \mathrm{ml}$ with significant fluctuation between 1990 and 1997 (Figure 1.4). Levels of tritium in the other two shallow wells are lower by at least a factor of ten. Even though soil moisture tritium concentrations have exceeded the EPA drinking water standard of $20 \mathrm{pCi} / \mathrm{ml}$, no shallow well water sample has ever been above the EPA drinking water standard of $20 \mathrm{pCi} / \mathrm{ml}$. The discrepancy between soil water 
Table 4.5 CP-5 Monitoring Well Specifications

\begin{tabular}{||c|c|c|c|c|c||}
\hline ID No. & Depth $^{1}$ & $\begin{array}{c}\text { Ground } \\
\text { Elevation }^{2}\end{array}$ & Monitoring Zone $^{3}$ & Well Type $^{4}$ & Date Drilled $^{2}$ \\
\hline \hline 330011 & 20 & 745.5 & $10-20 / 736-726$ & $2 / \mathrm{PVC}$ & $8 / 89$ \\
\hline 330021 & 19 & 746.5 & $4-19 / 743-728$ & $2 / \mathrm{SS}$ & $9 / 93$ \\
\hline 330031 & 17.1 & 742.1 & $2-17 / 740-725$ & $2 / \mathrm{SS}$ & $9 / 93$ \\
\hline $330012 \mathrm{D}$ & 140 & 745 & $122-137 / 623-608$ & $2 / \mathrm{SS}$ & $6 / 97$ \\
\hline
\end{tabular}

'Feet Below Ground $\quad{ }^{3}$ Depth/Elevation

${ }^{2}$ Feet Mean Sea Level $\quad{ }^{4}$ Inner Diam.(in)/Well Material

Table 4.6 Tritium Concentrations in CP-5 Monitoring Wells

\begin{tabular}{|c|c|c|c|c||}
\hline Sample Date & $\begin{array}{c}\text { MW 330011 South } \\
(\mathrm{pCi} / \mathrm{ml})\end{array}$ & $\begin{array}{c}\text { MW 330021 East } \\
(\mathrm{pCi} / \mathrm{ml})\end{array}$ & $\begin{array}{c}\text { MW 330031 } \\
\text { South (pCi/m) }\end{array}$ & $\begin{array}{c}\text { MW 330012D } \\
\text { South pCi/ml) }\end{array}$ \\
\hline \hline $4-09-90$ & 15.9 & N/A & N/A & N/A \\
\hline $6-19-90$ & 10.0 & N/A & N/A & N/A \\
\hline $10-24-90$ & 6.6 & N/A & N/A & N/A \\
\hline $11-16-90$ & 6.5 & N/A & N/A & N/A \\
\hline $3-22-90$ & 6.5 & N/A & N/A & N/A \\
\hline $5-14-91$ & 5.8 & N/A & N/A & N/A \\
\hline $9-10-91$ & 5.7 & N/A & N/A & N/A \\
\hline $12-6-91$ & 4.0 & N/A & N/A & N/A \\
\hline $6-26-92$ & 13.9 & N/A & N/A & N/A \\
\hline $10-16-92$ & 10.2 & N/A & N/A & N/A \\
\hline $11-09-92$ & 8.2 & N/A & N/A & N/A \\
\hline $3-24-93$ & 6.8 & N/A & N/A & N/A \\
\hline $6-24-93$ & 4 & N/A & N/A & N/A \\
\hline $9-20-93$ & 3.5 & N/A & N/A & N/A \\
\hline $11-19-93$ & 8.2 & 0.20 & 0.33 & N/A \\
\hline $3-15-94$ & 5.5 & & & \\
\hline
\end{tabular}




\section{INVESTIGATION OF TRITIUM SOIL}

\section{CONTAMINATION IN THE CP-5 YARD}

Page 26 of 118

\begin{tabular}{|c|c|c|c|c|}
\hline Sample Date & $\begin{array}{c}\text { MW 330011 South } \\
(\mathrm{pCi} / \mathrm{ml})\end{array}$ & $\begin{array}{c}\text { MW 330021 East } \\
(\mathrm{pCi} / \mathrm{ml})\end{array}$ & $\begin{array}{c}\text { MW 330031 } \\
\text { South (pCi/ml) }\end{array}$ & $\begin{array}{c}\text { MW 330012D } \\
\text { South pCi/mi) }\end{array}$ \\
\hline \hline $6-22-94$ & 14.3 & 0.14 & 0.46 & N/A \\
\hline $9-16-94$ & 15 & 0.48 & 0.22 & N/A \\
\hline $11-29-94$ & 7.8 & 0.30 & 0.44 & N/A \\
\hline $3-09-95$ & 7.8 & 0.23 & 0.34 & N/A \\
\hline $5-31-95$ & 4.4 & 0.10 & 0.28 & N/A \\
\hline $8-29-95$ & 9.2 & 0.15 & 0.31 & N/A \\
\hline $11-10-95$ & 5.1 & 0.18 & 0.27 & N/A \\
\hline $3-05-96$ & 10.6 & 0.20 & 0.21 & N/A \\
\hline $5-28-96$ & 6.9 & 0.12 & 0.27 & N/A \\
\hline $9-16-96$ & 9.4 & 0.19 & 0.33 & N/A \\
\hline $11-14-96$ & 4.7 & 0.17 & 0.29 & N/A \\
\hline $3-11-97$ & 6.3 & 0.12 & 0.22 & $<0.10^{14}$ \\
\hline $6-17-97$ & 7.9 & 0.16 & 0.24 & 0.140 \\
\hline $9-10-97$ & 3.1 & 0.17 & 0.23 & 0.330 \\
\hline $11-24-97$ & 5.3 & 0.26 & 0.21 & $0.16^{15}$ \\
\hline $3-19-98$ & 0.8 & $<0.1$ & 0.16 & $<0.10^{15}$ \\
\hline $6-01-98$ & 0.8 & 0.20 & & \\
\hline
\end{tabular}

tritium concentration data, which indicate tritium concentrations in excess of $20 \mathrm{pCi} / \mathrm{ml}(2.6 \mathrm{pCi} / \mathrm{g}$ dry soil with a $13 \%$ moisture content) and shallow groundwater tritium concentrations which are all $<20 \mathrm{pCi} / \mathrm{ml}$, may be a reflection of the dilution occurring within the water bearing, courser grained soils (sandy, gravelly, clay) in the CP-5 yard compared to the tritium-saturated pore space in impermeable clay soil. Nevertheless, these results suggest that deep ground water concentrations of tritium under CP-5 are unlikely to approach $20 \mathrm{pCi} / \mathrm{ml}$ in the future. In addition, the slowly decreasing tritium concentrations indicated by shallow groundwater well monitoring data reflect the slow migration of tritium through the impermeable glacial till underlying CP-5.

\footnotetext{
${ }^{14}$ Memo, N. Golchert to R. Coley, "Results of initial tritium sampling from the CP-5 Dolomite Well, 7/1/97

${ }^{15}$ Monitoring results from N. Golchert to R. Hysong
} 


\subsubsection{Dolomite Groundwater Monitoring}

In June 1997, a deep monitoring well (330012D) was installed approximately $12 \mathrm{ft}$ west of shallow monitoring well 330011 (Figure 1.2) to monitor the tritium levels in the dolomite groundwater. Dolomite bedrock was encountered while drilling the deep well at the 126-ft deep point, but drilling continued for $14 \mathrm{ft}$ prior to well installation. The deep well monitoring results first indicated a slight increase in tritium concentration in November 1997, but the latest results from the June 1998 sampling are again below detection limits $(<0.1 \mathrm{pCi} / \mathrm{ml})$.

\subsection{Miscellaneous Sampling Results}

\subsubsection{Fuel Pool Liner Investigation}

In November 1997, a small, 1/8-in diameter hole was discovered in the spent fuel pool stainless steel liner. As indicated in Figure 1.3, the hole is located at the north end of the fuel pool floor ( $25 \mathrm{ft}$ below grade) approximately 2 feet from the north pool wall midway between the east and west walls. ${ }^{16}$ Thirty gallons of tritium-contaminated water $(1,520 \mathrm{pCi} / \mathrm{ml})$ were pumped from between the metal pool liner and the concrete pool foundation. ${ }^{17}$ Tritium concentrations in an 8-in core of the upper fuel pool foundation (pool side) concrete are shown in Table 4.7 below. The deepest ( 5 to 9 in) section of concrete core contained $56 \mathrm{pCi} / \mathrm{g} \mathrm{H}-3$. Since the pool foundation is $3-\mathrm{ft}$ thick, it would appear that migration of tritium from the pool concrete was minimal. Cs-137 concentrations in each core section were $<0.2 \mathrm{pCi} / \mathrm{g}$.

Table 4.7 Tritium Concentration in Fuel Pool Floor Concrete ${ }^{18}$

\begin{tabular}{|c|c|}
\hline $\begin{array}{c}\text { Core Section } \\
\text { (in deep from pool floor) }\end{array}$ & $\begin{array}{c}\text { Tritium Concentration } \\
\text { ( } \mathrm{pCi} / \mathrm{g} \text { ) }\end{array}$ \\
\hline \hline $0-1$ & 210 \\
\hline $1-2.5$ & 125 \\
\hline $2.5-5$ & 54 \\
\hline $5-9$ & 56 \\
\hline
\end{tabular}

\footnotetext{
${ }^{16}$ Memo, R. Ditch to R. Rose, "Discovery of a hole in the CP-5 Fuel Pool Liner", 11/21/97

${ }^{17}$ ANL-E Analytical Chemistry Laboratory, "Report of Analytical Results", Sample No. 98-8036-01 through -04

${ }^{18}$ ANL-E Analytical Chemistry Laboratory, "Report of Analytical Results", Sample Nos. 98-8094-01
} 


\subsubsection{CP-5 Reactor Building Drain Tile System}

In March 1998, sampling of sludge and water from the rod-out holes on the south and west sides of the CP-5 service floor was performed. The water levels in the rod-out holes were all well below the level at which the clay pipes enter the rod-out holes (at approximately $14 \mathrm{ft}$ below grade). Tritium water concentrations from the holes shown in Table 4.8 below ranged from $<0.33 \mathrm{pCi} / \mathrm{ml}$ to $327 \mathrm{pCi} / \mathrm{ml}$ with the highest concentration coming from a rod-out hole (DR2) located on the south side of CP-5 adjacent to the CP-5 yard (Figure 4.4). The tritium concentrations measured in DR1, $\mathrm{DR} 2$ and DR3 suggest that operational personnel may have released secondary system cooling water contaminated with tritium into the drain tile system which leads to the ANL-E sanitary drain system.

Table 4.8 Rod-Out Hole Sampling Results ${ }^{19}$

\begin{tabular}{||c|c|c|c|c||}
\hline \hline Sample $\mathrm{D}$ & $\begin{array}{c}\text { Water } \\
\text { H-3 } \\
(\mathrm{pCi} / \mathrm{ml})\end{array}$ & $\begin{array}{c}\text { Sludge } \\
\text { Ra-226 } \\
(\mathrm{pCi} / \mathrm{g})\end{array}$ & $\begin{array}{c}\text { Sludge } \\
\text { Cs-137 } \\
(\mathrm{pCi} / \mathrm{g})\end{array}$ & $\begin{array}{c}\text { Sludge } \\
\text { Co-60 } \\
(\mathrm{pCi} / \mathrm{g})\end{array}$ \\
\hline \hline DR1 S/W & $190 \pm 2$ & $0.5 \pm 0.1$ & $2.6 \pm 0.1$ & $1.1 \pm 0.1$ \\
\hline $\mathrm{DR} 2 \mathrm{~S} / \mathrm{W}$ & $327 \pm 3$ & $0.5 \pm 0.1$ & $3.9 \pm 0.2$ & $<0.2$ \\
\hline DR3 S/W & $26.2 \pm 0.7$ & $1.2 \pm 0.1$ & $28 \pm 1$ & $1.7 \pm 0.1$ \\
\hline DR4 S/W & $<0.33$ & $0.4 \pm 0.1$ & $<0.2$ & $<0.2$ \\
\hline AW SUMP & $<0.33$ & $0.6 \pm 0.06$ & $<0.2$ & $<0.2$ \\
\hline
\end{tabular}

${ }^{19}$ ANL-E ACL "Report of Analytical Results" Sample No.s 98-8140-01 through -05 


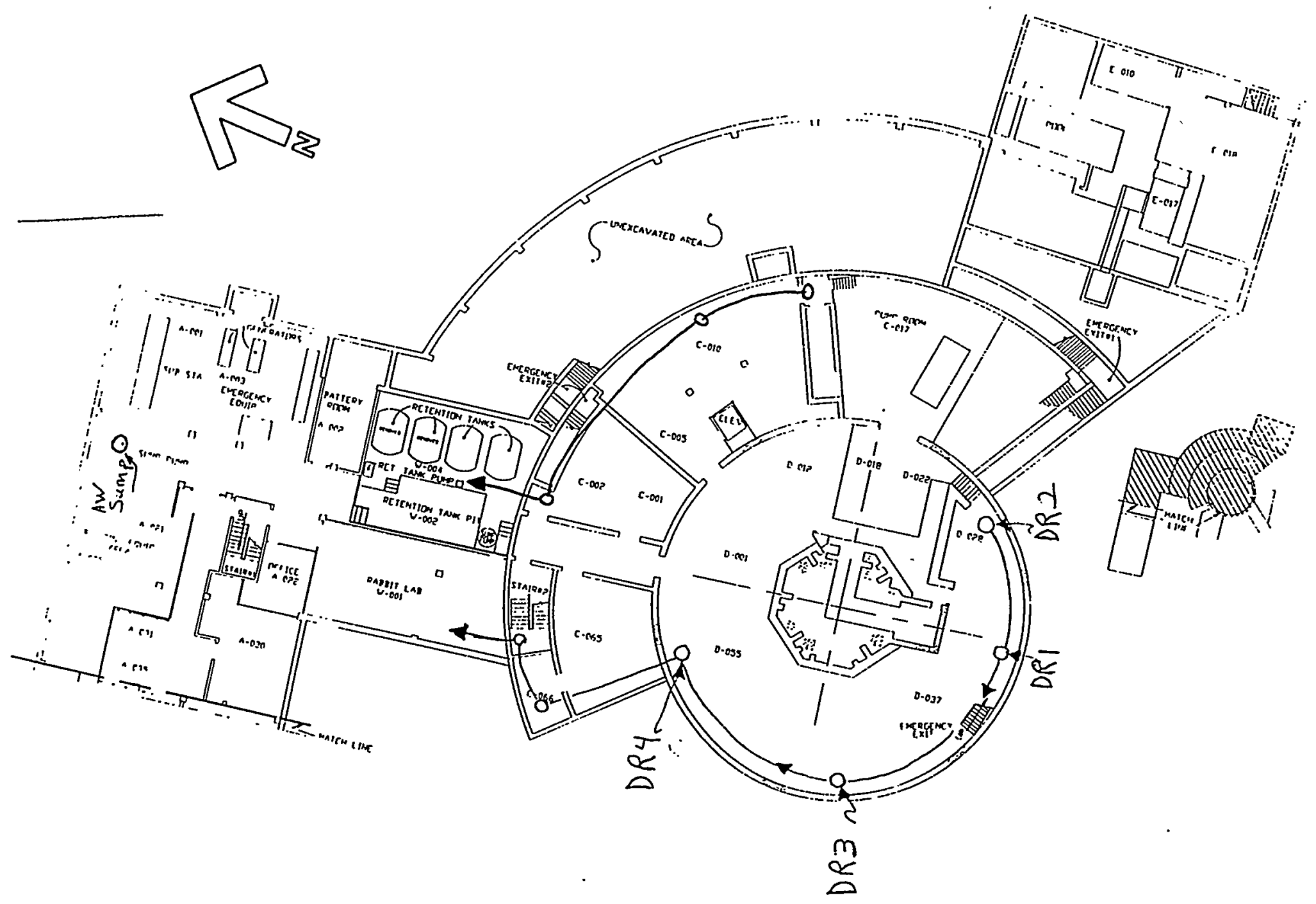

Figure 4.4 CP-5 Service Floor 


\subsection{RESRAD DOSE ASSESSMENT INPUT PARAMETERS}

One RESRAD calculation has been performed to estimate the conservative, upper-bound potential radiological impacts from tritium soil contamination in the CP-5 yard. This case is based on the worst-case residential family-farm scenario in which the source of water for drinking, household uses, irrigation, and livestock watering is assumed to be a local well drilled at the downgradient edge of the contaminated zone which contains a homogeneous concentration of tritium. A graphical representation of RESRAD residential family-farm scenario pathways is shown in Figure 5.1.

The soil guideline concentration has been derived using a $25 \mathrm{mrem} / \mathrm{yr}$ basic dose limit in order to ensure that potential doses from residual tritium at the CP-5 site are well below the requirements of DOE Order 5400.5, which specifies an annual dose limit of $100 \mathrm{mrem}$. In addition, a $25 \mathrm{mrem} / \mathrm{yr}$ dose limit was chosen because it represents the lowest dose limit criterion used by a federal agency (Nuclear Regulatory Commission) for the unrestricted release of property containing residual radioactive material. ${ }^{20}$ EPA has a dose-based limit of $4 \mathrm{mrem} / \mathrm{yr}$ for the drinking water pathway, as well as a concentration-based limit of $20 \mathrm{pCi} / \mathrm{ml}$ for tritium.

Table 5.1 contains a summary of RESRAD input parameters used in this analysis and the references on which they are based. Appendices E and F contain the RESRAD Summary Report and Detailed RESRAD Report, respectively.

The area of the rectangular-contaminated zone is conservatively assumed to extend from underneath the middle of the CP-5 reactor building southward $38 \mathrm{~m}$ to monitoring well 330031 , and from the west yard fence line east $64 \mathrm{~m}$ to monitoring well 330021 (Figure 4.1). This area encompasses the area under E-Wing and approximately half the area under the CP-5 reactor building. Tritium concentrations in the east and south wells drop off significantly and are indicative of a much lower tritium soil concentration (approximately $0.05 \mathrm{pCi} / \mathrm{g}$ assuming a $13 \%$ water content) averaged over their monitoring zones. Two thousand four hundred thirty square meters is a very conservative estimation of the contaminated area, given the results of CP-5 yard sampling which indicate that less than one quarter of the yard is contaminated with over $1 \mathrm{pCi} / \mathrm{g}$ tritium (i.e., $7.7 \mathrm{pCi} / \mathrm{ml}$ tritium in soil water).

The thickness of the contaminated zone is $15.24 \mathrm{~m}$ based on the $1997,50-\mathrm{ft}$ soil core results obtained from the most contaminated $100 \mathrm{~m}^{2}$ area identified in the $1993 \mathrm{IT}$ characterization encompassing sample locations SB03, SB04 and SB05. The thickness of the contaminated zone under the reactor building and under E-Wing are conservatively over estimated because of the presence of the reactor building foundation and E-Wing pool foundation. An uncontaminated, $1.5-\mathrm{m}$ thick cover has also been used because the concentration of tritium in surface soil at CP-5 is negligible (IT 1994).

\footnotetext{
${ }^{20}$ Federal Register, Vol.2, No. 139. Monday, July 21, 1997
} 


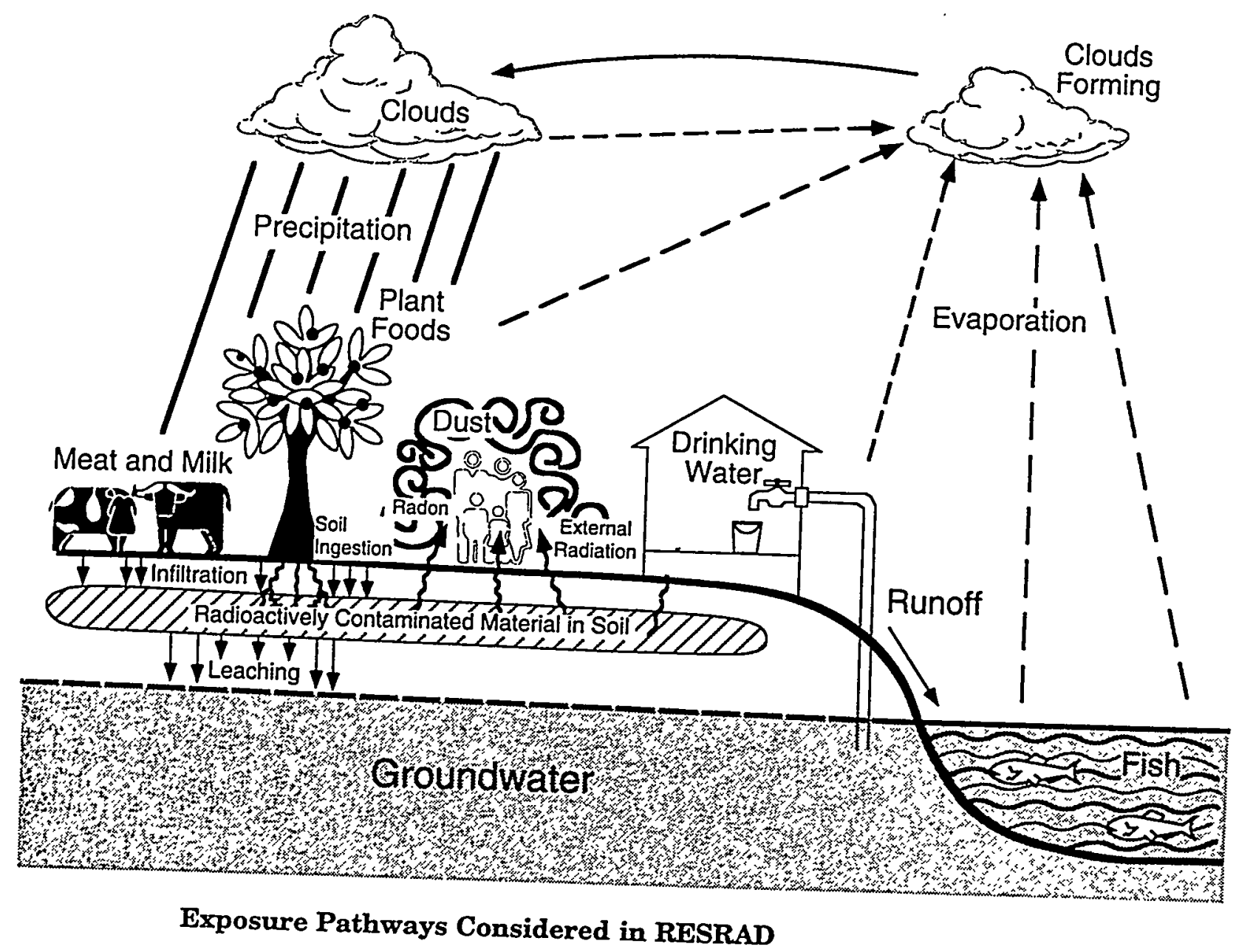

Figure 5.1 RESRAD Family-Farm Pathways 
The length parallel to aquifer flow is the horizontal dimension of contaminated zone parallel to the groundwater flow direction. The length of contaminated zone parallel to aquifer flow is conservatively assumed to be the maximum horizontal distance within the contaminated zone or the diagonal line cutting across the contaminated zone ( $38 \mathrm{~m} \times 64 \mathrm{~m}$ rectangle) from NW to SE $(74 \mathrm{~m})$.

The initial principle radionuclide concentration in the homogeneous contaminated zone $(6.9 \mathrm{pCi} / \mathrm{g})$ has been derived by averaging the results of the 1997, 50-ft core samples obtained from an area of relatively high tritium soil contamination compared to the rest of the yard.

Geological and hydrogeological parameters relating to the contaminated and underlying unsaturated zone 1 are based on previous RESRAD evaluations at ANL-E in the 317 area (Kou et al. 1997). Based on a review of core logs and well installation stratigraphic columns, the Wadsworth layer of the $317 / 319$ Area appears to be composed of the same glacial till (silty clay) as that found in the CP-5 area. The 317/319 Area also contains shallow groundwater where precipitation is able to migrate through small fractures in the weathered portions of the clay and in small sand and gravel lenses similar to the CP-5 yard (Patton et al. 1990). The well pump intake depth is conservatively assumed to be $5 \mathrm{~m}$ below the water table instead of the 10-m RESRAD default. The parameters used for the second underlying unsaturated zone (Unsat-2 consisting of upper and middle Lemont Formation units) are based on the parameters for silty clay loam (Yu et al. 1993).

Table 5.1 RESRAD Input Parameters

\begin{tabular}{||l|c|c||}
\hline \multicolumn{1}{|c|}{ RESRAD Input Parameter } & $\begin{array}{c}\text { Family-Farm } \\
\text { Scenario }\end{array}$ & Reference \\
\hline \hline Area of the contaminated zone $\left(\mathrm{m}^{2}\right)$ & 2430 & CP-5 Yard Sampling \\
\hline Thickness contaminated zone (m) & 15.24 & 50-ft Soil Boring 1997 \\
\hline Length (m) parallel to aquifer flow & 74 & Calculated Based on Worst Case Geometry \\
\hline Dose limit (mrem) & 25 & Lowest Federal Limit \\
\hline Initial H-3 soil conc. (pCi/g) & 6.9 & 50-ft Soil Boring 1997 \\
\hline Density of contaminated zone & 1.76 & Kou et al. 1997 \\
\hline Contaminated zone total porosity & 0.3 & Kou et al. 1997 \\
\hline Contaminated zone effective porosity & 0.2 & Kou et al. 1997 \\
\hline $\begin{array}{l}\text { Contaminated zone hydraulic } \\
\text { conductivity (m/y) }\end{array}$ & 0.95 & Kou et al. 1997 \\
\hline Contaminated zone b parameter & 11.4 & Kou et al. 1997 \\
\hline Cover thickness (m) & 1.5 & IT 1994 \\
\hline
\end{tabular}




\section{INVESTIGATION OF TRITIUM SOIL CONTAMINATION IN THE CP-5 YARD}

\begin{tabular}{|c|c|c|}
\hline RESRAD Input Parameter & $\begin{array}{c}\text { Family-Farm } \\
\text { Scenario } \\
\end{array}$ & Reference \\
\hline Humidity $\left(\mathrm{g} / \mathrm{cm}^{3}\right)$ & 7 & Yu et al. 1993 \\
\hline Precipitation (m/y) & 0.8 & Golchert et al. 1996 \\
\hline Saturated zone total porosity & 0.3 & Kou et al. 1997 \\
\hline Saturated zone effective porosity & 0.2 & Kou et al. 1997 \\
\hline Saturated zone hydraulic conductivity $(\mathrm{m} / \mathrm{y})$ & 950 & Kou et al. 1997 \\
\hline Saturated zone $b$ parameter & 11.4 & Kou et al. 1997 \\
\hline Well pump intake depth (m below water table) & 5 & Kou et al. 1997 \\
\hline Number unsat zones & 2 & Argonne 1997 \\
\hline Unsat zone 1 thickness (m) & 2.5 & Argonne 1997 \\
\hline $\begin{array}{l}\text { Unsat zone } 1 \\
\text { total porosity }\end{array}$ & 0.3 & Kou et al. 1997 \\
\hline Unsat zone 1 effective porosity & 0.2 & Kou et al. 1997 \\
\hline $\begin{array}{l}\text { Unsat zone } 1 \\
\text { b parameter }\end{array}$ & 11.4 & Kou et al. 1997 \\
\hline $\begin{array}{l}\text { Unsat zone } 1 \\
\text { hydraulic conductivity }(\mathrm{m} / \mathrm{y})\end{array}$ & 1 & Kou et al. 1997 \\
\hline Unsat zone 2 thickness (m) & 18.3 & Argonne 1997 \\
\hline $\begin{array}{l}\text { Unsat zone } 2 \\
\text { total porosity }\end{array}$ & 0.3 & Yu et al. 1993 \\
\hline Unsat zone 2 effective porosity & 0.2 & Yu et al. 1993 \\
\hline $\begin{array}{l}\text { Unsat zone } 2 \\
\text { b parameter }\end{array}$ & 7.75 & Yu et al. 1993 \\
\hline $\begin{array}{l}\text { Unsat zone } 2 \\
\text { hydraulic conductivity }(\mathrm{m} / \mathrm{y})\end{array}$ & 50 & Yu et al. 1993 \\
\hline
\end{tabular}




\subsection{RESULTS OF DETERMINISTIC DOSE ASSESSMENT}

The RESRAD computer code, version 5.82 was used to calculate the potential radiation dose for a residential family-farm scenario at the $\mathrm{CP}-5$ complex. The time frame considered in this analysis was only 100 years due to the short half-life of tritium (12.35 y). Doses calculated by RESRAD are always relative to the time at which the radiological survey was performed to collect input data (December 1997). A summary of the RESRAD results is presented in Table 6.1 below.

Table 6.1 Potential Radiological Impacts Estimate Summary

\begin{tabular}{|c|c|c|c|c|c|c|}
\hline $\begin{array}{c}\text { Soil } \\
\text { Guideline } \\
\text { (pCi/g) }\end{array}$ & $\begin{array}{c}\text { RESRAD } \\
\text { Well } \mathrm{H}_{2} \mathrm{o} \\
\text { pCi/l @ t=0 } \\
\text { yr. 12/97 } \\
\end{array}$ & $\begin{array}{c}\text { RESRAD } \\
\text { Well } \mathrm{H}_{2} \mathrm{o} \\
\mathrm{pCi} / \mathrm{l} @ \mathrm{t}=1 \\
\mathrm{yr} .12 / 98 \\
\end{array}$ & $\begin{array}{l}\text { Year of } \\
\text { Maximum } \\
\text { Dose }\end{array}$ & $\begin{array}{c}\text { Maximum } \\
\text { Dose } \\
\text { (mrem) }\end{array}$ & $\begin{array}{c}\text { Dose } \\
\text { Limit } \\
\text { (mrem) }\end{array}$ & $\begin{array}{c}\text { Percent } \\
\text { of Dose } \\
\text { Limit }\end{array}$ \\
\hline 164 & 28,000 & 24,000 & 1997 & 1.05 & 25 & 4 \\
\hline
\end{tabular}

The soil guideline level for a $15.24-\mathrm{m}$ thick contaminated zone having an area of $2,430 \mathrm{~m}^{2}$ is $164 \mathrm{pCi} / \mathrm{g}$, approximately four times higher than the highest tritium concentration measured (42 pCi/g) during CP-5 investigative sampling. In addition, the $42 \mathrm{pCi} / \mathrm{g}$ measurement was from a sample less than $1 \mathrm{~m}$ thick. The concentration in drinking water from a theoretical well located at the downgradient edge of the contaminated zone at the time of obtaining the $50-\mathrm{ft}$ core (December 1997) is $28,000 \mathrm{pCi} / /(28 \mathrm{pCi} / \mathrm{ml})$. Note that RESRAD output data and graphical output is in units of $\mathrm{pCi} /$. The annual effective dose equivalent resulting from all pathways is $1.05 \mathrm{mrem}$. Figure 6.1 shows the dose from all pathways as a function of time measured from year zero or December 1997.

\subsection{PARAMETER SENSITIVITY ANALYSIS}

Figure 7.1 shows the individual dose component pathways. As illustrated in Figure 7.1, the drinking water pathway is the dominant pathway for dose from tritium-contaminated soil in the CP-5 yard. Consequently, the calculated doses will be sensitive to parameters that affect the drinking water pathway. Figure 7.2 shows the concentration of tritium in well water used for drinking as a function of time.

A sensitivity analysis was performed on the geologic and hydrogeologic parameters which affect the concentration of tritium in well water used in the family-farm scenario. Significant parameters identified in the sensitivity analyses were the length parallel to aquifer flow, the hydraulic conductivities of the saturated and contaminated zones, and the effective porosity of the unsaturated and saturated zones. The effect of these parameters can be seen in Figures 7.3 through 7.7. Note 
DOSE: H-3, All Pathways Summed

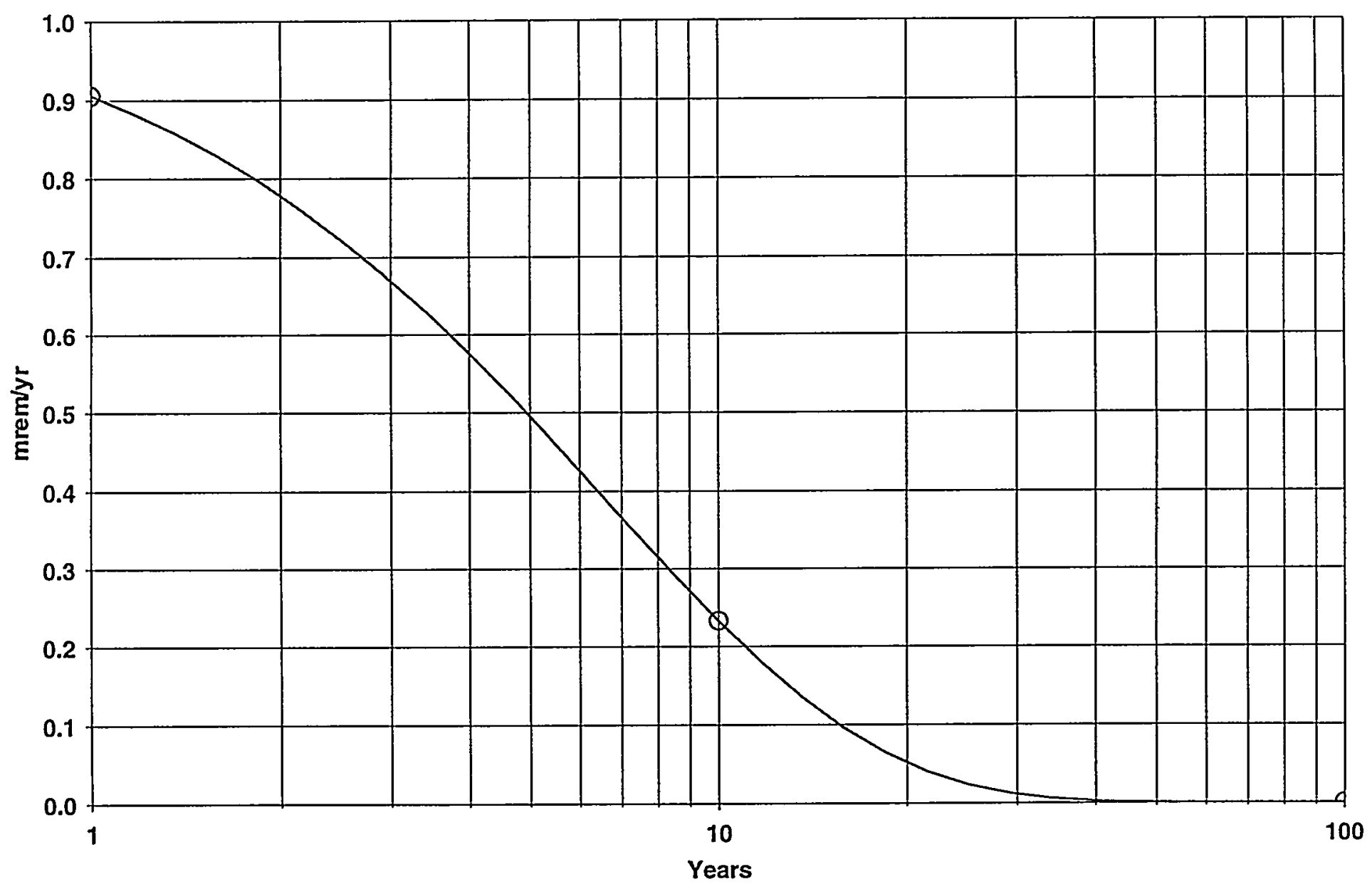

CP5OSITE.RAD 11/04/98 10:56 Includes All Pathways

Figure 6.1 Family-Farm Scenario Dose as a Function of Time 
DOSE: H-3, Component Pathways

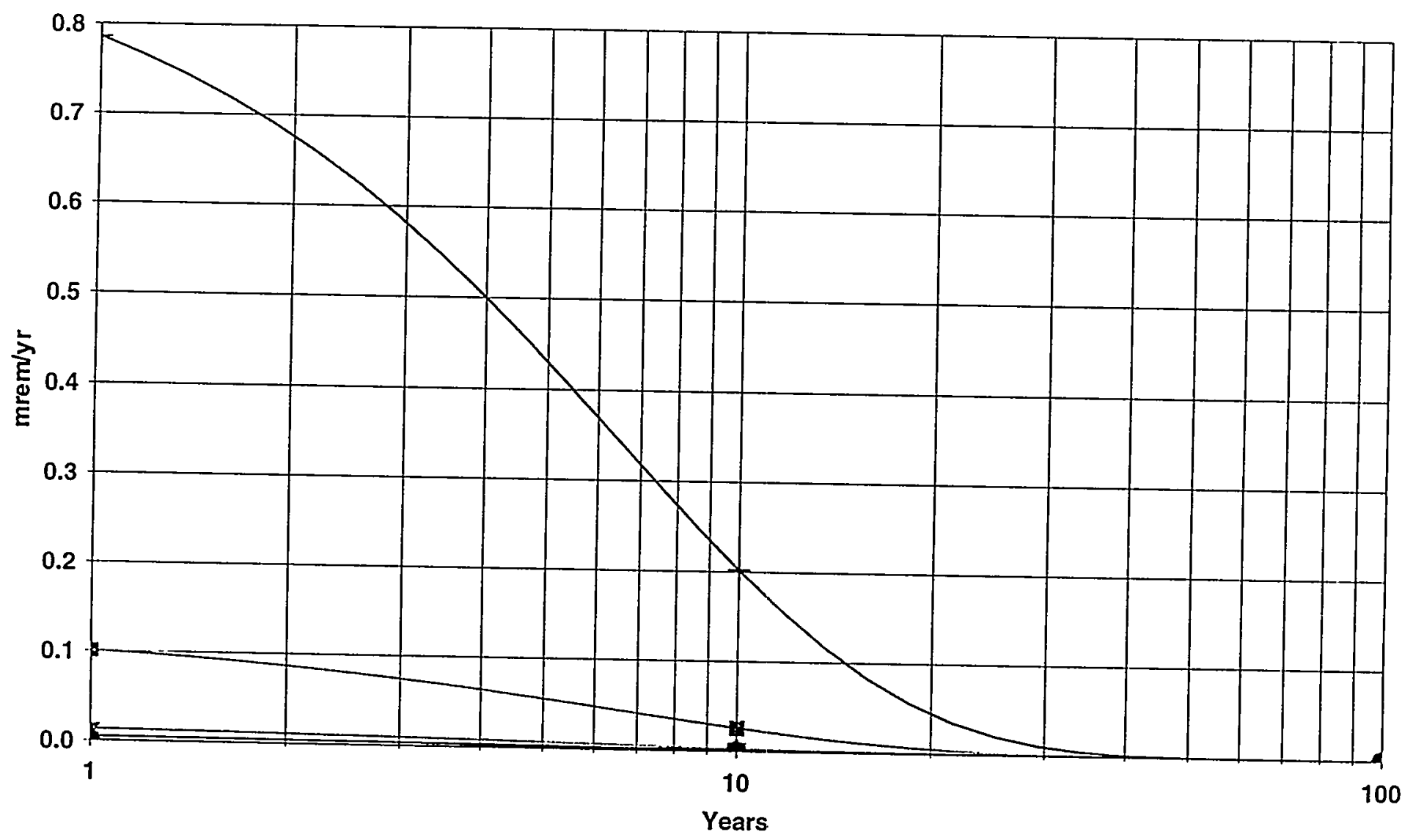

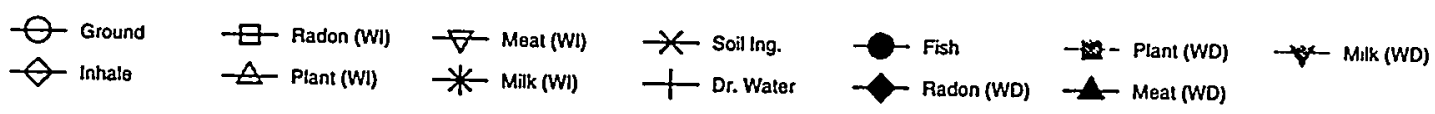

CP5OSITE.RAD 11/04/98 10:56 Includes All Pathways

Figure 7.1 Family-Farm Dose Component Pathways 
CONCENTRATION: H-3, Well Water

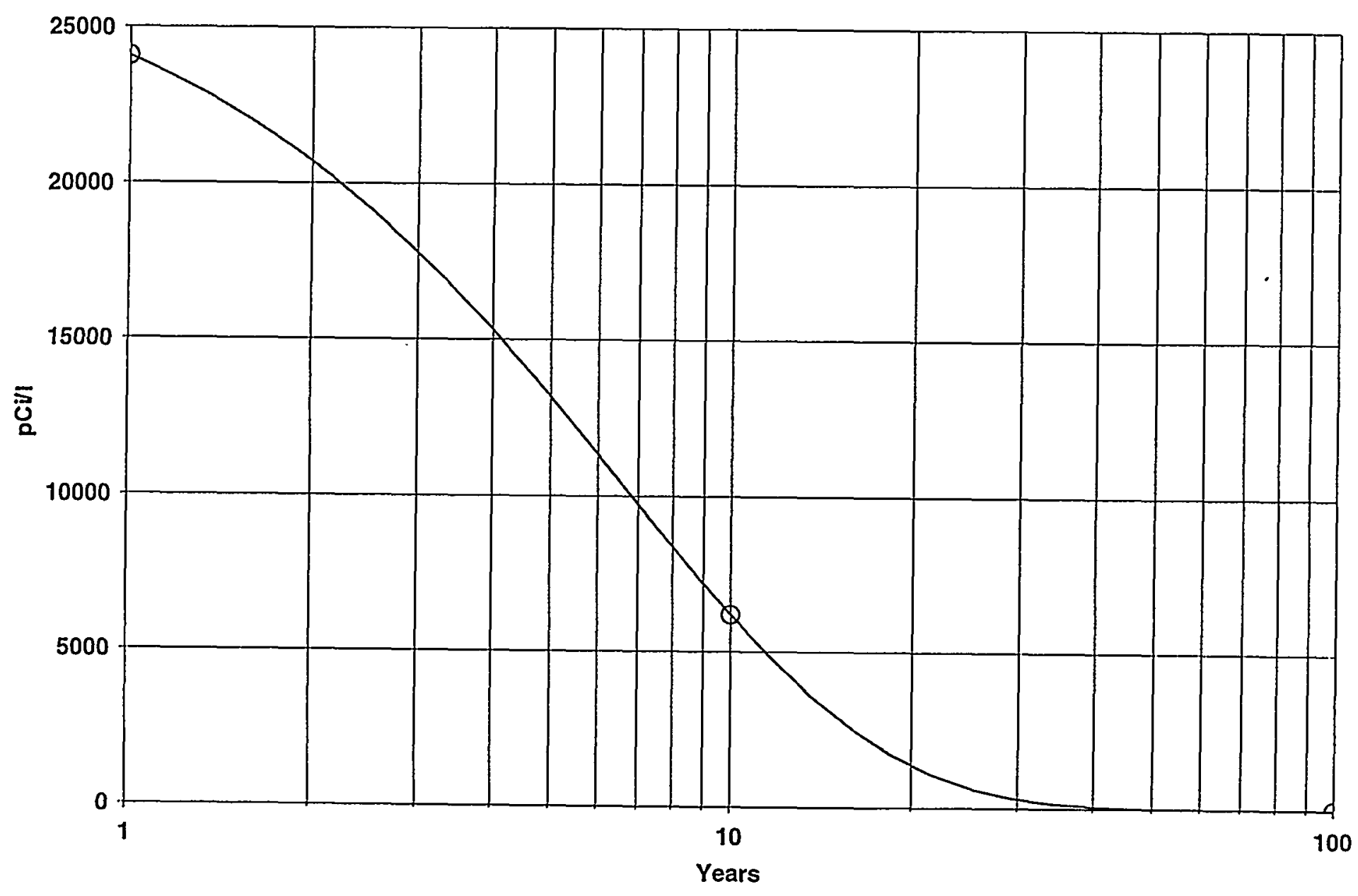

CP5OSITE.RAD 11/04/98 10:56

Figure 7.2 Concentration of Tritium in Well Water as a Function of Time 
CONCENTRATION: H-3, Well Water With SA on Length parallel to aquifer flow

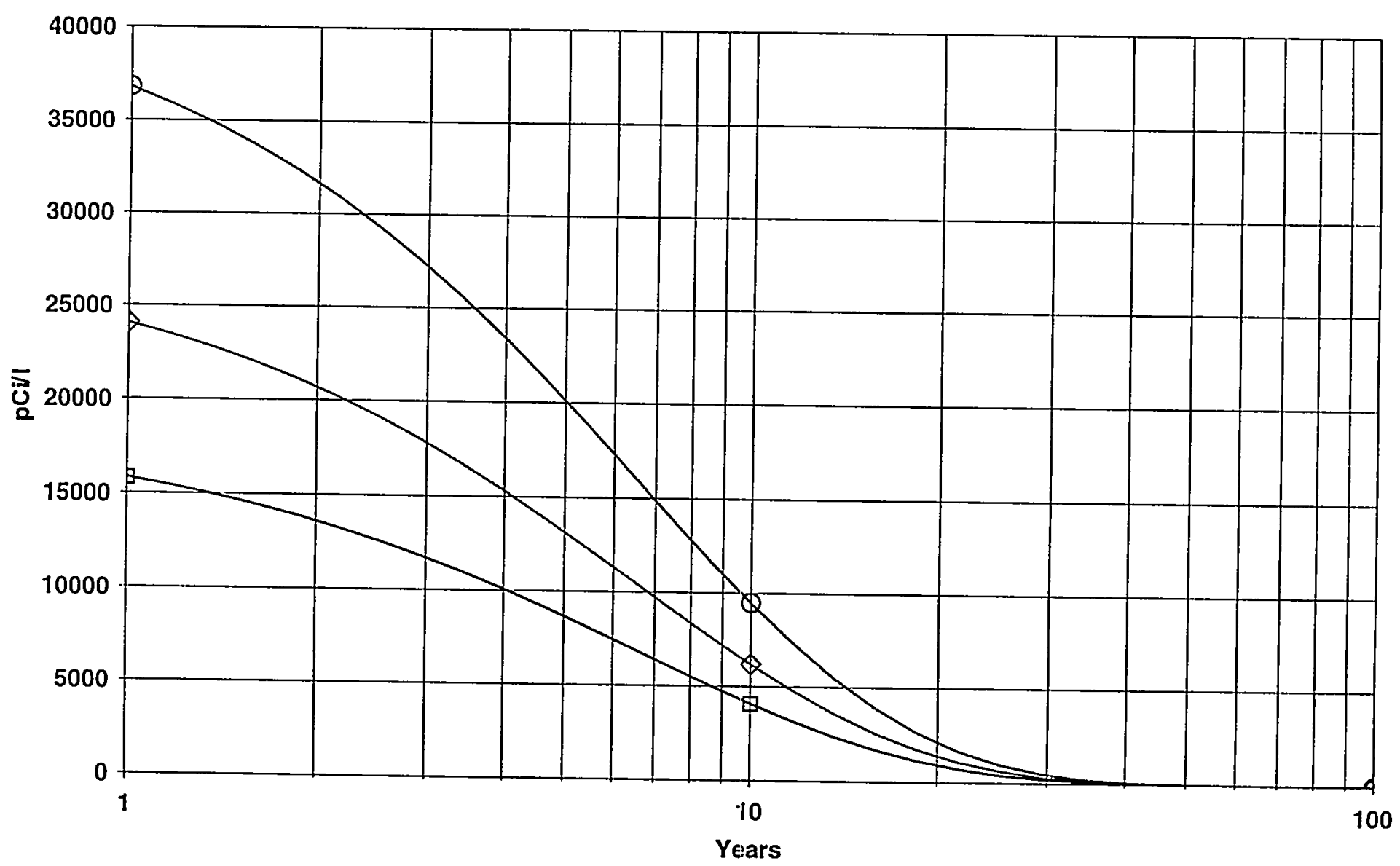

$\vartheta$ Upper: $111 \quad \diamond$ Mid: $74 \quad \square$ Lower. 49.3333

CPSOSITE.RAD 11/04/98 10:56

Figure 7.3 Sensitivity Analysis on Length Parallel to Aquifer Flow 
CONCENTRATION: H-3, Well Water With SA on Saturated zone hydraulic conductivity

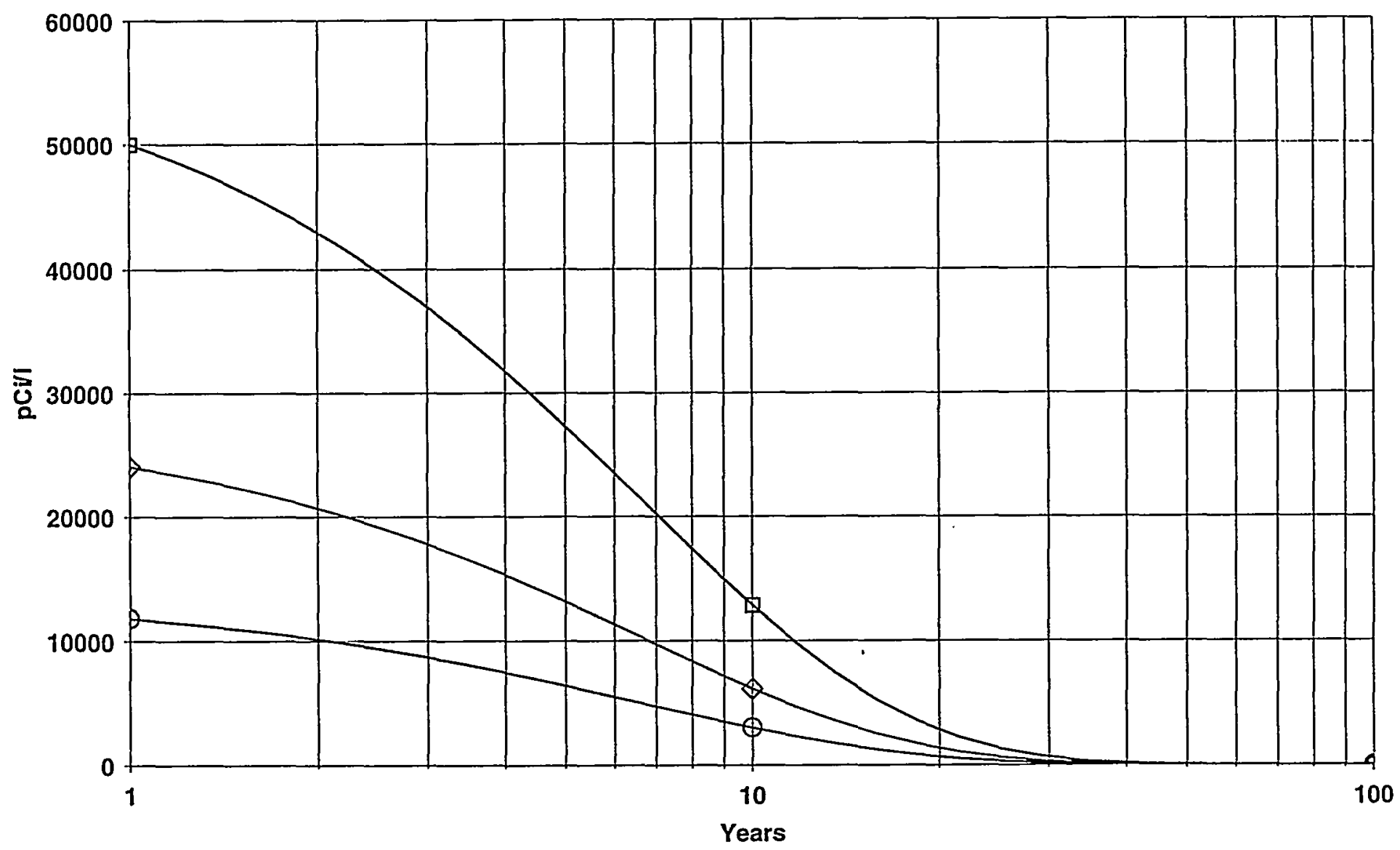

$\vartheta$ - Upper: $1900 \quad \vartheta$ Mid: 950 $\quad$ - Lower: 475

CP5OSITE.RAD 11/04/98 11:06

Figure 7.4 Sensitivity Analysis on Saturated Zone Hydraulic Conductivity 
CONCENTRATION: H-3, Well Water With SA on Contaminated zone hydraulic conductivity

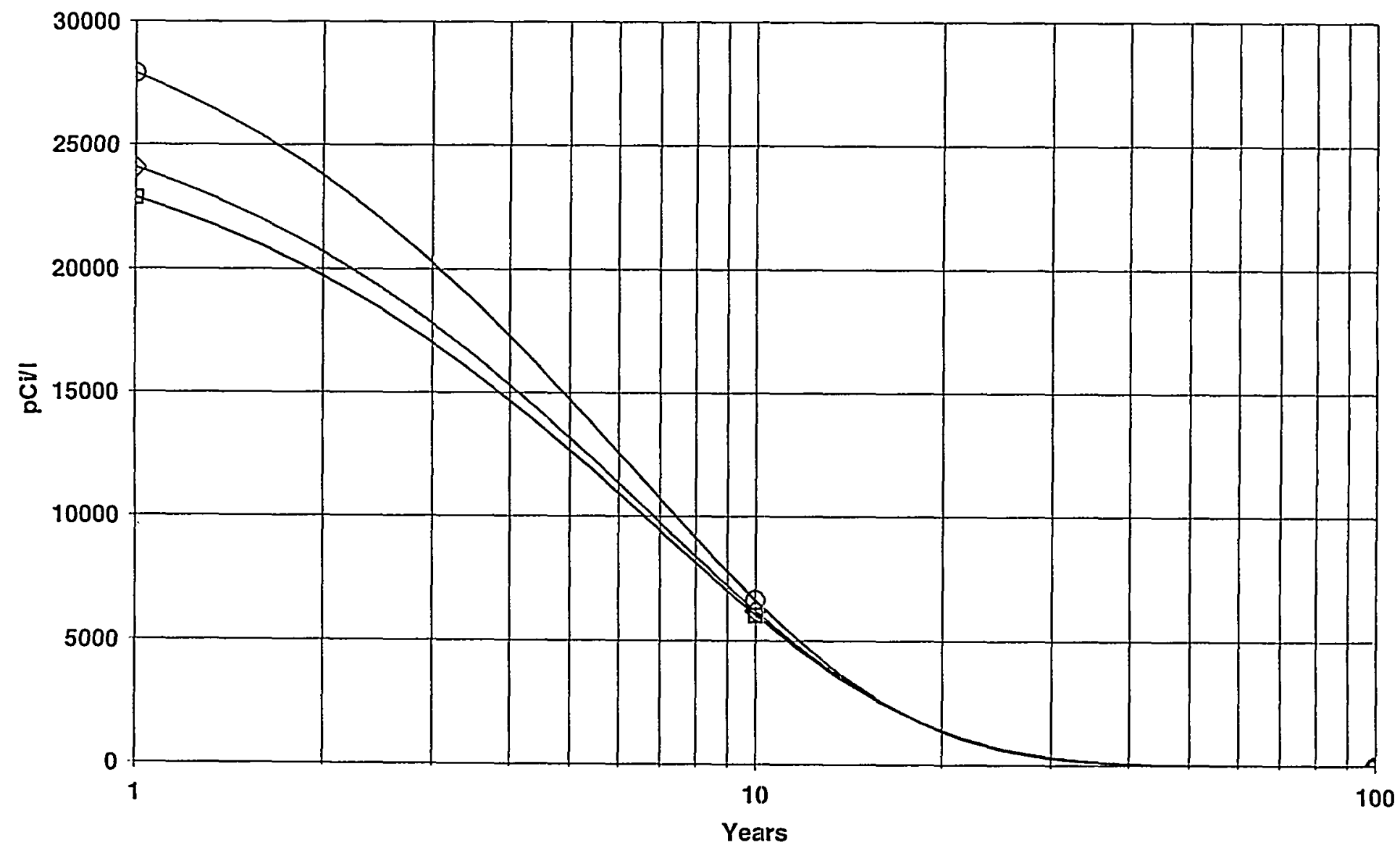

$\bigoplus$ Upper. $9.5 \diamond$ Mid: .95 Ð Lower. 095

CP5OSITE.RAD 11/04/98 11:06

Figure 7.5 Sensitivity Analysis on Contaminated Zone Hydraulic Conductivity 
CONCENTRATION: H-3, Well Water With SA on Effective Porosity of Unsaturated Zone 1

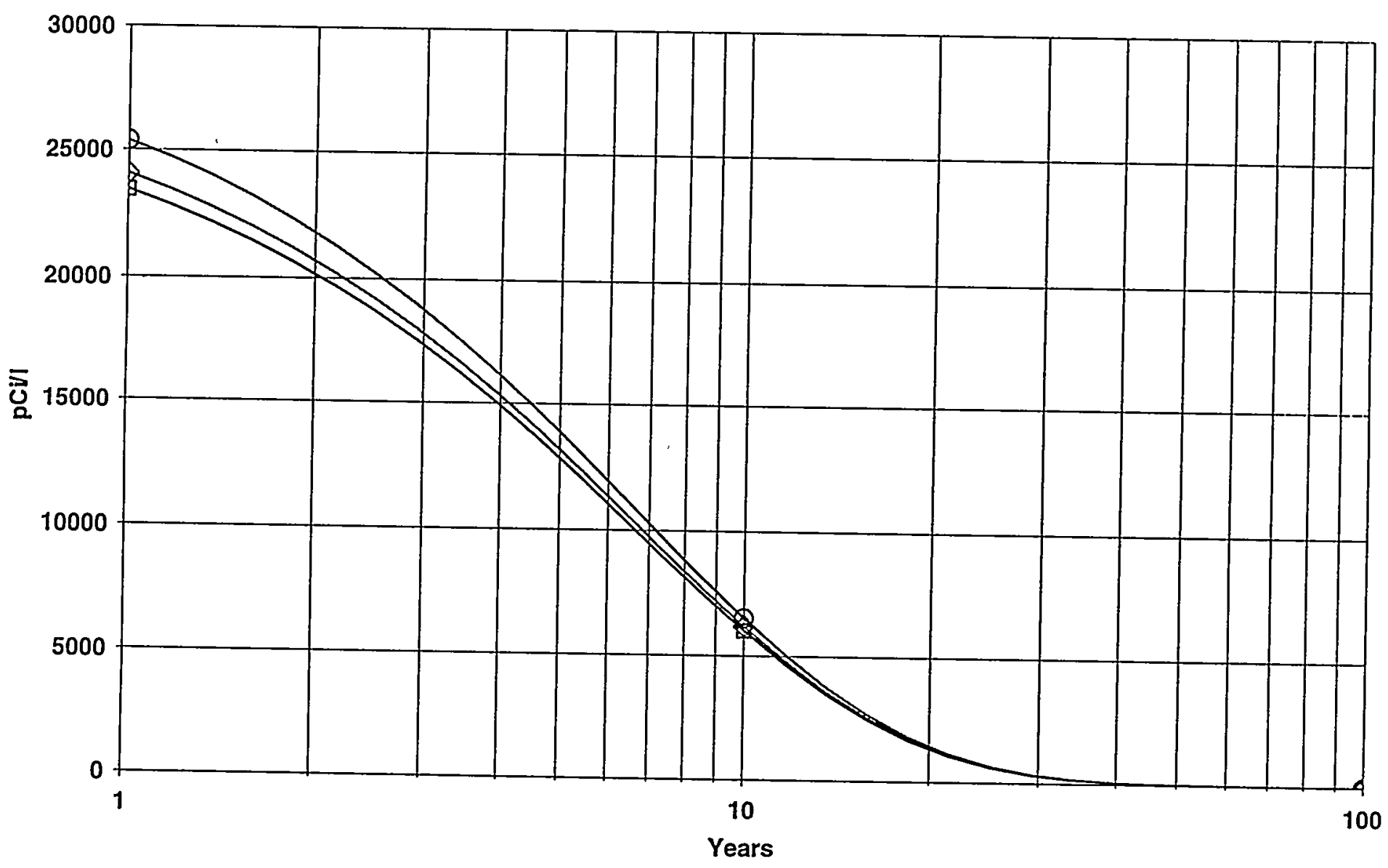

$\theta$ Upper. .4 $\diamond$ Mid: $2 \quad \square$ Lower. .1

CP5OSITE.RAD 11/04/98 11:06

Figure 7.6 Sensitivity Analysis on Unsaturated Zone 1 Effective Porosity 
CONCENTRATION: H-3, Well Water With SA on Saturated zone effective porosity

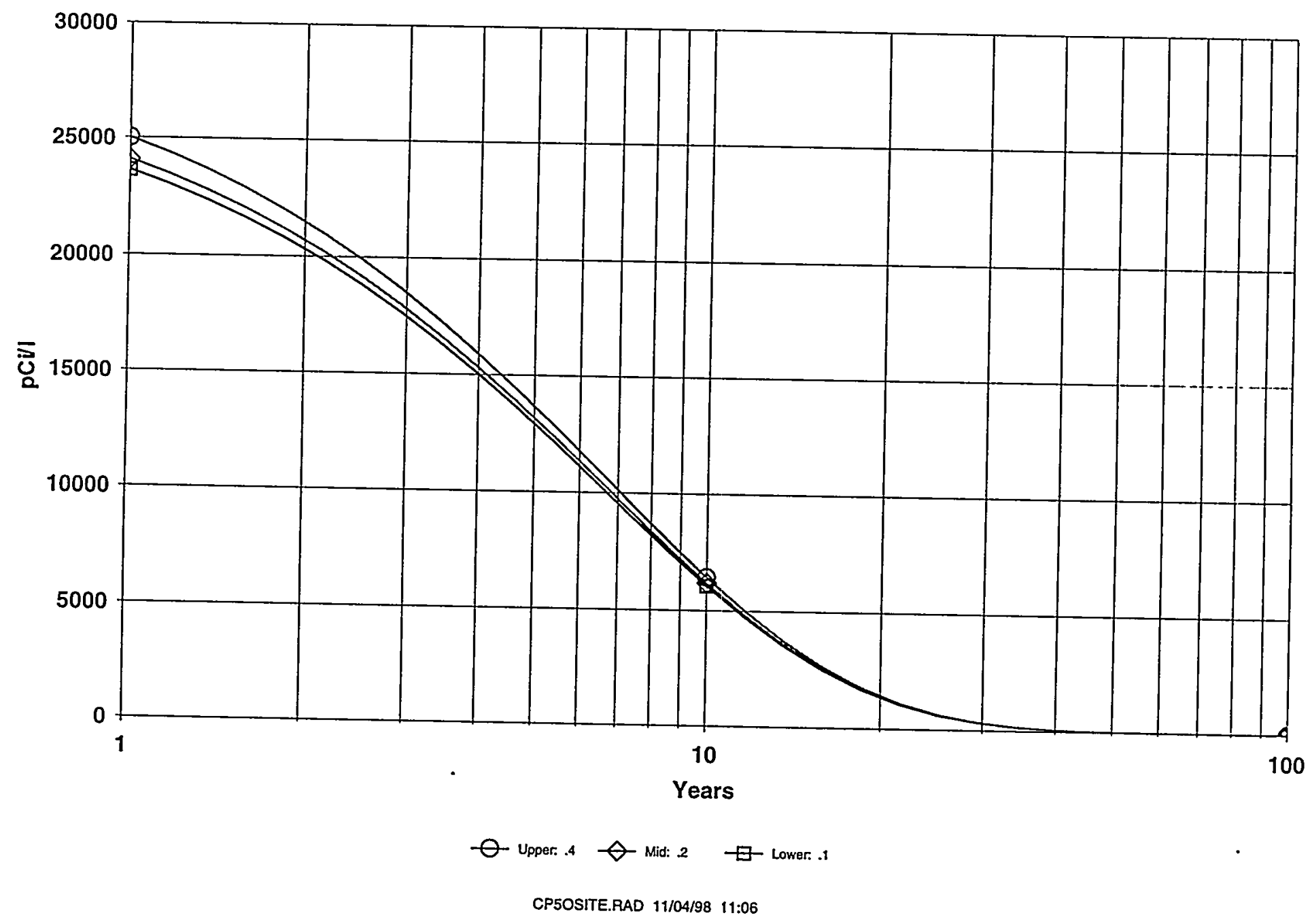

Figure 7.7 Sensitivity Analysis on Saturated Zone Effective Porosity 
that RESRAD graphical output data is in units of pCi/l. Based on CP-5 yard soil sampling and well monitoring, the actual length parallel to aquifer flow of $74 \mathrm{~m}$ used in this analysis is much more likely to approach the lower value of $49 \mathrm{~m}$ shown in Figure 7.3, because of the conservative overestimate of the area of the contaminated zone. In addition, the saturated hydraulic conductivity of the saturated zone is more likely to be greater than $500 \mathrm{~m} / \mathrm{y}$ as shown in Figure 7.4 due to the presence of sands and gravels in the basal Lemont unit of the glacial till directly overlying the dolomite and due to channelized flow in fractures in the dolomite aquifer. In any case, the peak dose (at time zero) changes by less than a factor of approximately 2.5 within a wide, conservative range of parameter change.

\subsection{DISCUSSION}

\subsection{Residential Family-Farm Scenario Impacts}

A residential family-farm scenario located on the tritium-contaminated soil around the CP-5 complex has been evaluated to conservatively estimate the magnitude of the on-site radiological impacts from tritium-contaminated soil in the CP-5 yard. The geological and hydrogeological parameters used in this analysis are generally conservative with respect to the rate of downward tritium migration to the dolomite aquifer, the concentration of tritium in the yard, and the size of the contaminated zone. In addition, the presence of the CP-5 Reactor Building foundation and E-Wing pool foundation have been ignored and are assumed to contain tritium-contaminated soil. Lastly, the infiltration rate of water into the contaminated zone has been overestimated by neglecting the presence of the Reactor Building and E-Wing roof tops, which intercept rainfall.

Sampling results from the deep, dolomite aquifer well (330012D) located within the contaminated zone south of the CP-5 reactor building do not indicate that significant migration of tritium down to the dolomite groundwater has occurred. The slow decrease in tritium concentrations in samples from the shallow well (330011) behind the CP-5 reactor building also indicate that the downward migration of tritium through the glacial till is very slow. Based on the time that has elapsed since the deposition of tritium into and onto CP-5 yard soils, and given the decreasing tritium concentration profile in the 50 -ft soil boring, it is likely that the family-farm scenario dose estimate of 1.05 mrem represents a significant overestimate of radiological impacts. Likewise, off-site radiological impacts, if any, would be small to negligible.

In the very worst case, one would have to assume that a series of interconnected sand and/or gravel formations exists in the glacial till underlying CP-5. Experimental leaching tests of tritium in a sand and gravel column with a water content of $20 \%$ (similar to the volumetric water content of ANL-E glacial till) indicate that $85 \%$ of the tritium in the sand and gravel column are only released from the column after water weighing $20 \%$ of the weight of the column percolates through the column (Baker 1975). In other words, there would be a dilution factor of about 2.3 simply due to the amount of water necessary to leach and transport the tritium from its present location. If a series of sand and gravel lenses containing an average of $6.9 \mathrm{pCi} / \mathrm{g}(34.5 \mathrm{pCi} / \mathrm{ml}$ soil water) of tritium existed in a 
narrow channel (over $60 \mathrm{ft}$ long) from the tritium-contaminated volume in the CP-5 yard soil down to the dolomite groundwater, a pulse-type release of tritium would be expected to produce a peak concentration of approximately $15 \mathrm{pCi} / \mathrm{ml}$ before depleting $85 \%$ of the tritium along the channel. A tritium concentration of $15 \mathrm{pCi} / \mathrm{ml}$ is less than the EPA drinking water standard of $20 \mathrm{pCi} / \mathrm{ml}$.

\subsection{Industrial Use Scenario}

The current plans are to complete the D\&D of the entire CP-5 Complex in the near future. Under the less conservative, but more realistic industrial-use scenario, one might expect that soil excavation activities may proceed in the CP-5 yard for approximately one year for some type of construction project. Since tritium only decays by a low energy beta emission, it is primarily an internal hazard. Consequently, the inhalation dose equivalent from working $2,000 \mathrm{hr} / \mathrm{yr}$ would be no greater than the inhalation dose at time zero in the residential scenario considered above with no clean soil cover, or $2.7 \times 10^{-3} \mathrm{mrem}$. Likewise, the ingestion dose from incidental soil ingestion would not be expected to be greater than the ingestion dose equivalent of $1.2 \times 10^{-5} \mathrm{mrem}$. Consequently, under the industrial-use scenario in the year 2000, the worst case, realistic dose equivalent would be $2.4 \times 10^{-3} \mathrm{mrem}$ under an industrial use scenario.

\subsection{CONCLUSIONS/RECOMMENDATIONS}

Based on a review of available data, significant contributions to low-level tritium soil contamination in the CP-5 yard have been made by airborne tritium fallout and rainout from the CP- 5 ventilation system stack. Based on the distribution of tritium in the yard, it is also likely that leaks in secondary system piping which lead to the cooling towers were a significant contributor to tritium in CP-5 yard subsurface soil.

Based on the foregoing analysis, low-level tritium contamination will not prohibit the release of the yard for unrestricted use in the future. Worst case dose estimates based on very conservative assumptions indicate that a $25 \mathrm{mrem}$ annual effective dose equivalent limit will not be exceeded under the most restrictive residential-use family farm scenario. Given the impermeable nature of the glacial till under CP-5, low-level concentrations of tritium may be occasionally detected in the deep well (330012D), but the peak concentration will not approach the levels calculated by RESRAD; however, continued monitoring of the deep well is recommended.

To ensure that all sources of potential tritium release have been removed from the CP- 5 complex, removal of tritiated water from each rod-out hole and an evaluation of the physical integrity of the rod-out holes is recommended. This will also allow for an evaluation of tritium concentrations in shallow groundwater under CP-5 by sampling groundwater that is currently being forced into the drain tile system.

Additional surface and subsurface soil sampling and analysis will be required to determine the final release status of soils around the Building 330 complex relative to elevated concentrations of Cs-137, 
Co-60, Co-57, and Eu-152 identified during the 1993 IT Corporation characterization. The potential radiological impact from isolated elevations of the latter radionuclides is relatively low and can be evaluated as part of the final status survey of outdoor areas surrounding the Building 330 complex.

In summary, the following activities are recommended:

- $\quad$ Remove tritiated water from each rod-out hole

- Monitor rod-out hole tritium concentrations as they fill up with shallow groundwater

- Continue groundwater monitoring

- Perform surface and subsurface soil sampling around the CP-5 complex as part of the final status survey 


\subsection{REFERENCES}

Argonne, 1998, Quicksite Report: Stage 1 Argonne-East Geologic/Hydrogeologic Model Based on Existing Data and Limited Field Investigations, Applied Geosciences and Environmental Management Section, Environmental Research Division, Argonne National Laboratory, Argonne Il, May 1998.

Argonne, 1997, Quicksite Analysis of Geologic/Hydrogeologic Data for Argonne-East and Proposed Hydrogeologic Site Investigation, Vol. 1, Applied Geosciences and Environmental Management Section, Environmental Research Division, Argonne National Laboratory, Argonne Il, June 1997.

Argonne, 1965, Environmental Radioactivity at Argonne National Laboratory Report for 1964, Argonne Report ANL-7104, Iwami, F.S. and Sedlet, J. Argonne National Laboratory, Argonne IL.

Baker, S., 1975, "Soil Activation Measurements at Fermi Lab," paper presented at the Third Environmental Protection Conference, Washington, DC, DOE Publication ERDA-92, CONF-750967, 329-346, 1975.

Fetter, C., Jr., Applied Hydrogeology, Charles E. Merril Publishing Company, Columbus OH, 1980.

Golchert, N.W. and R.G. Kolzow, 1998, Argonne National Laboratory-East Site Environmental Report for Calendar Year 1997, Argonne Report ANL-98/2, Argonne National Laboratory, Argonne II.

Golchert, N.W. and R.G. Kolzow, 1997, Argonne National Laboratory-East Site Environmental Report for Calendar Year 1996, Argonne Report ANL-97/6, Argonne National Laboratory, Argonne II.

Golchert, N.W. and R.G. Kolzow, 1996, Argonne National Laboratory-East Site Environmental Report for Calendar Year 1995, Argonne Report ANL-96/3, Argonne National Laboratory, Argonne II.

Golchert, N.W. and R.G. Kolzow, 1995, Argonne National Laboratory-East Site Environmental Report for Calendar Year 1994, Argonne Report ANL-95/8, Argonne National Laboratory, Argonne II.

Golchert, N.W. and R.G. Kolzow, 1994, Argonne National Laboratory-East Site Environmental Report for Calendar Year 1993, Argonne Report ANL-94/10, Argonne National Laboratory, Argonne $\mathbb{Z}$. 
Golchert, N.W. and R.G. Kolzow, 1993, Argonne National Laboratory-East Site Environmental Report for Calendar Year 1992, Argonne Report ANL-93/5, Argonne National Laboratory, Argonne L.

Golchert, N.W., Duffy, T.L., and Moos, L.P., 1992, Argonne National Laboratory-East Site Environmental Report for Calendar Year 1991, Argonne Report ANL-92/14, Argonne National Laboratory, Argonne IL.

Golchert, N.W., Duffy, T.L., and Moos, L.P, 1991, Argonne National Laboratory-East Site Environmental Report for Calendar Year 1990, Argonne Report ANL-91/3, Argonne National Laboratory, Argonne IL.

Golchert, N.W. and R.G. Kolzow, 1990, Argonne National Laboratory-East Site Environmental Report for Calendar Year 1989, Argonne Report ANL-90/8, Argonne National Laboratory, Argonne IL.

Golchert, N., Duffy,T., Sedlet, J., 1983, ANL-E Site Environmental Report for Calendar Year 1982, Argonne National Laboratory, Argonne Report ANL-83-26, Argonne IL.

Geraghty and Miller, 1995, Final Phase 1 Hydrogeological Assessment Report-ANL, Geraghty and Miller Inc., Milwaukee WI, April 1995.

IT, 1994, Final CP-5 Yard Characterization Report, IT Corporation, Itasca, IL, February.

Killey, M. and Trask, C., Geotechnical Site Investigation for an Advanced Photon Source at Argonne National Laboratory, Ilinois State Geological Survey, Champaign II, 1994.

Kou, J., Moos, L., Yu, C., and Gabel, A., "Radiological Risks and Cleanup Costs: A Remediation Case Study;" Remediation, Summer/1997, John Wiley \& Sons, Inc.

Patton, T., Pearl, R., Tsai, S., 1990, Hydrological Conditions at the 317/319 Area at Argonne National Laboratory, Environmental Assessment and Information Sciences Division, Argonne Report ANL/EAIS/TM-28, Argonne National Laboratory, Argonne II.

STS, 1990, Title II Subsurface Exploration and Geotechnical Engineering Evaluation for the Proposed $7 \mathrm{GeV}$ Advanced Photon Source (APS), STS Consultants, Ltd., Northbrook II, April 30, 1990.

Yu,C., et al., 1993, Manual for Implementing Residual Radioactivity Material Guidelines Using RESRAD Version 5.0, Argonne National Laboratory, Argonne Report ANL/EAD/LD-2 (September 1993). 


\subsection{ACRONYMS AND ABBREVIATIONS}

\begin{tabular}{|c|c|}
\hline $\mathrm{ACL}$ & Analytical Chemistry Laboratory, Argonne National Laboratory \\
\hline AMSL & Above Mean Sea Level \\
\hline ANL-E & Argonne National Laboratory-East, Argonne, Illinois \\
\hline APS & Advanced Photon Source \\
\hline$A^{2} R^{2}$ & Argonne Advanced Research Reactor \\
\hline $\mathrm{Ci}$ & curies \\
\hline $\mathrm{cm}$ & centimeter \\
\hline $\mathrm{CP}-5$ & Chicago Pile-Five \\
\hline EPA & U. S. Environmental Protection Agency \\
\hline $\mathrm{ESH}$ & Environment, Safety and Health Division, Argonne National Laboratory \\
\hline $\mathrm{ft}$ & foot \\
\hline g & gram \\
\hline gal & gallon \\
\hline IEPA & Illinois Environmental Protection Agency \\
\hline ISGS & Illinois State Geologic Survey \\
\hline in & inch \\
\hline $\mathrm{keV}$ & kilo electron volt \\
\hline $\mathrm{m}$ & meter \\
\hline $\mathrm{ml}$ & milliliter \\
\hline MW & million watt \\
\hline $\mathrm{pCi}$ & pico curie \\
\hline RESRAD & RESidual RADioactive computer code \\
\hline SWMU & Solid Waste Management Units \\
\hline $\mathrm{yr}$ & year \\
\hline
\end{tabular}


APPENDIX A

ILLINOIS ENVIRONMENTAL PROTECTION AGENCY WELL COMPLETION REPORT AND FIELD BORING LOG FOR WELL \# MW330012D AND BOREHOLE \# 330012D 
Illinoig Environmental Prolection Agency Well Completion Report s.t? 6 CounTr: DuPage NELS I: NH30012D

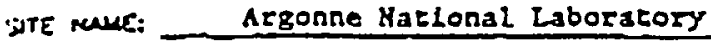
GOAEHOLE I: SB330012D STATE CODRONATE: $x$ $r$

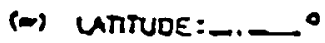
- L_Lnetude:

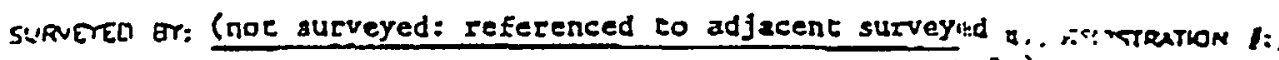

QRILUNC CONTRuCTOR: Patrlek Drilling, Ine. S.ER: I. ZwollnskI COHSULTHG FIRY: Crorocest: G. Hiteman, ANR GRIUNC UETHOO: Hollow-sCeM auger \& hYdraulfe rocary Draume rutos (mor) pocable vacer LocGED BT: G. HLEtman, ANL: DATE STARTED: 6/16/97 OATE ANTSHEO: 6/17/97 REPORT FORM COUPLETEO BT:

G. Herman DATE:

$7 / 8 / 97$

ANNULAR SPACE DETAILS

EIDYATIONS DEPTHS

(MSL) (BCS)

$(.01 \mathrm{rt})$

$742.5+2.5$

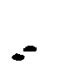

TrPe of SURFACE SEML_Cenent pad

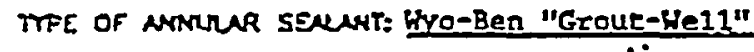
IMSTMLATON UETMO0: Erenie plpe SETRAC THE: 24 hourg

TPPE OF GENTONTE SEN - CRANUUR PAIET, SURRT (CRACE ONG) insturution uEROo: Eremie pipe SETINC THE: 2 hours

TPE OF SWD PAOX: GA-9 sil1c2 sand

CRNM SUER 10-20

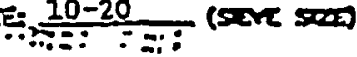

orstucunon METHoO: tremle plpe

TMPS OF BNOPL MTERLL None (I) Aproper

DNSTALTION HETHOO:

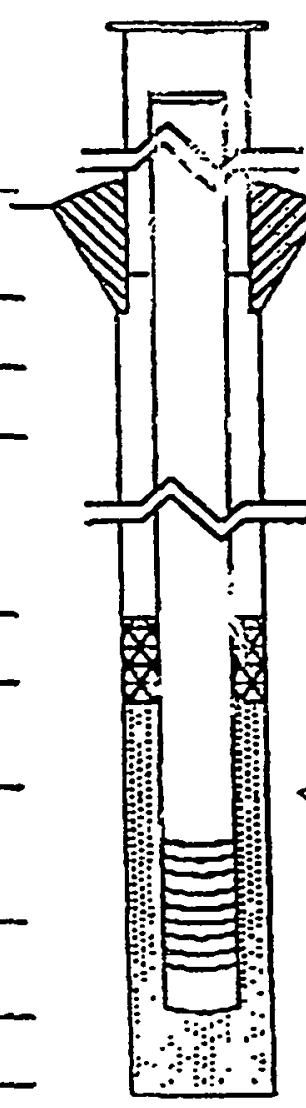

NELC CONSTRUCTION MATERIALS (CTRCLE ONE)

$247.3+2.3$ TOP OF RTSER POPE

$745-0$

745

627

627 128___ TOP of SEN $x 624\left(121^{\prime}\right) \quad 121 \ldots$ Top of suropscx

$\sqrt{\times 623}$ 122 TOP or scoens $\because=$

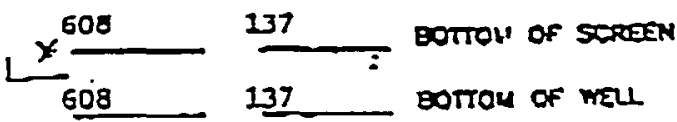
$605 \quad 140$ EOTTOL OF EOREHOR

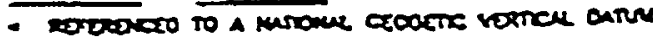
CASTNG YEASUREMENTS

\begin{tabular}{|c|c|}
\hline DUHETER OF BOREHOLE (in) & $g$ \\
\hline I0 OF RISER PIPE (in) & 2 \\
\hline PROTECTME CASINC LENGTH (II) & 5 \\
\hline RISER PIPE LENGTH (tt) & 124 \\
\hline BOTTOM OF SCREEN TO ENO CAP (1R) & 0 \\
\hline SCREEN LENGTHIIM sot to ust som (tt) & 15 \\
\hline TOTAL LENGTH OF CASING (II) & 240 \\
\hline SCREEN SLOT SIZE & 10 \\
\hline
\end{tabular}

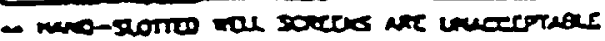

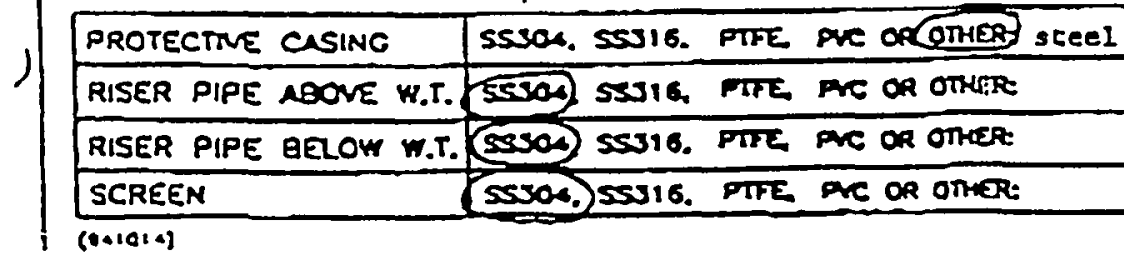




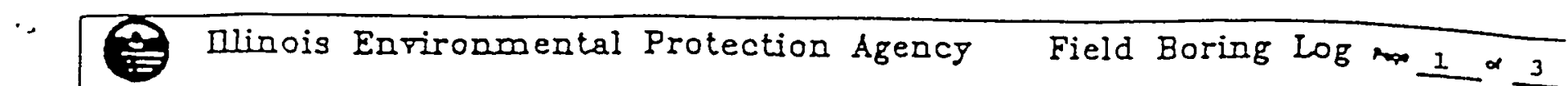

Sin F. $\mathrm{MO}=$ County DuPage

Sre Fue Mome Azgonne Vationa? Laboratory

Fod 10. No.

Quadragto Sag Bridge $\sec 9$ T. $37 \mathrm{~N}$ R. $11 E$ $E M$

Pron.) Coord. M.(x)

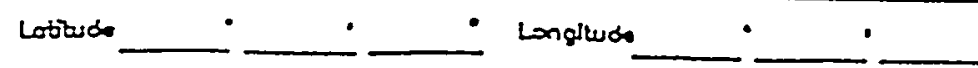

Boring Locotion S.E. of BuIld1ng 330, adjacent to MW330011 oning Equlpmont CME - Patrick Drilling, Inc.

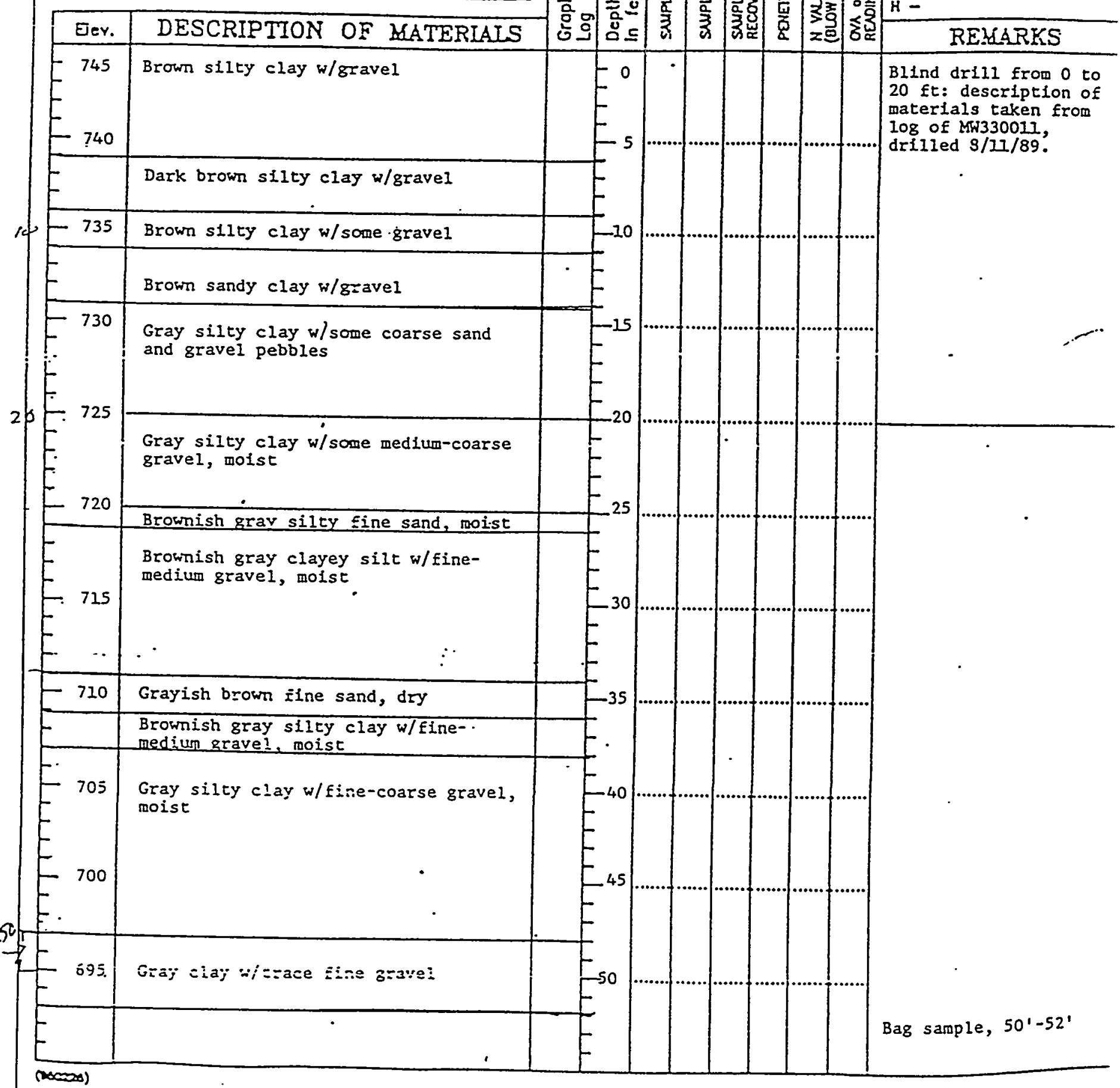

Eoring to. SB330012D_L_L Wonilor wat tio. sw330012D Nugar Doph ' $-126 \mathrm{ft}$ Rolory Dofs $140 \mathrm{ft}$ Dostar Stan F/9/97 Finion $6 / 23 / 97$

\begin{tabular}{|c|c|}
\hline SAMPLES & Perronnel \\
\hline
\end{tabular}

G - G, WLttman

D - T. Zwolinsk1

H - M. Gajos

4 -

Blind drill from 0 to 20 ft: description of materlals taken from 108 of MW330011, drilied $3 / 17 / 89$.

Bag sample, 50'-52' Surtoo Errojion $745 \mathrm{ft}$ msi Comptation caoth $140 \mathrm{ft}$ 
Sin F. Home Argonne National Laboratory Surtoo arrotion 745 ft ms Completion Casth $140 \mathrm{ft}$

Fad 10. No. Nugor Dopth $126 \mathrm{ft}$

Quodranth Sag Bridge $\sec$ 9 T. $37: \mathrm{N} R$ IIE Doter Stert $6 / 9 / 97$ Rolory Cojit $140 \mathrm{ft}$

UTh (or siote

Plon.) Coord. H.(x) $E(M)$

Lotiundo - $\quad$ Longlesda (1)

Boring Loction S.E. of Building 330, adjacent to MW33001I Driang Equlpment CME - Patrick Drililing, Inc.

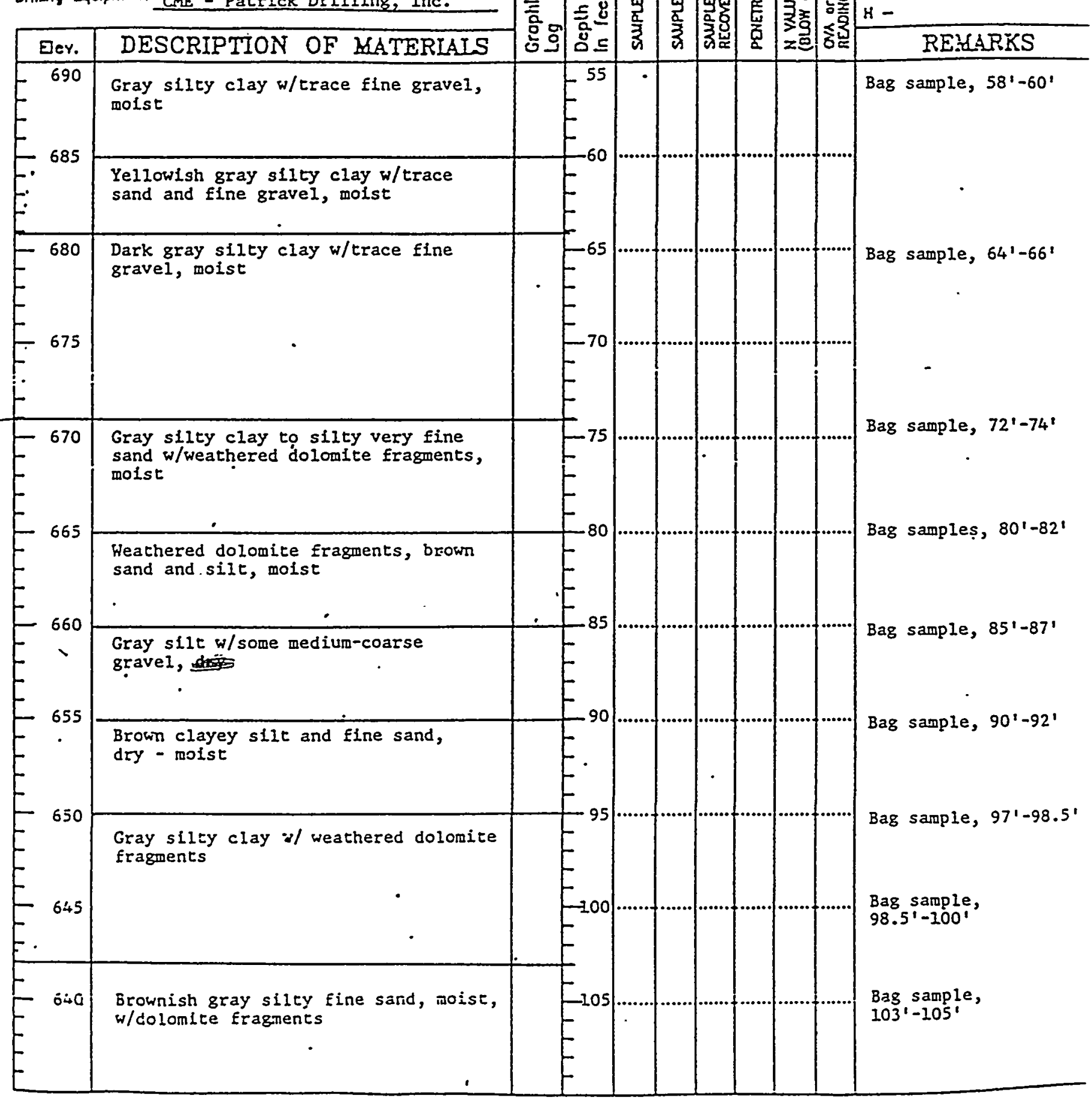

\begin{tabular}{|c|c|c|c|c|c|c|}
\hline \multicolumn{6}{|c|}{ SAMPLES } & Personnel \\
\hline 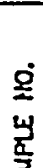 & 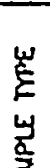 & 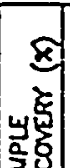 & 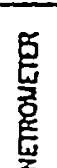 & 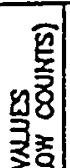 & 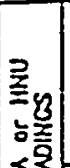 & $\begin{array}{l}\text { G- } \\
\text { D- } \\
\text { h- } \\
\mathrm{H}-\end{array}$ \\
\hline औ. & 3 & 次品 & 宫 & ze्ध & की & REXARKS \\
\hline
\end{tabular}


Illinois Enpironmental Protection Agency Field Boring Log 3 - 3

Sen R. Ho: County Dupage Boring to. SB330012D Wonitor wal kio: MW330012L

Ste Fie Mome Argonne National Laboratory

Fad 10. No. Nugor Copth 126 ft Complation Gaols $140 \mathrm{ft}$

Quodrants $\sec$ Dester sict $6 / 9 / 97$ Rolory Doris $140 \mathrm{Et}$ und (a stat.

Prone) Coord H.(x) $E(M)$

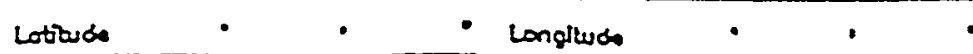

Boring Lootion S,E, of Bullding 330, adjacent to MW330011 Driang Equlpnont CaE - Patrick Drilling, Inc.

\begin{tabular}{|r|l|}
\hline Eer. & DESCRIPTION OF MATERIAIS \\
\hline 635 &
\end{tabular}

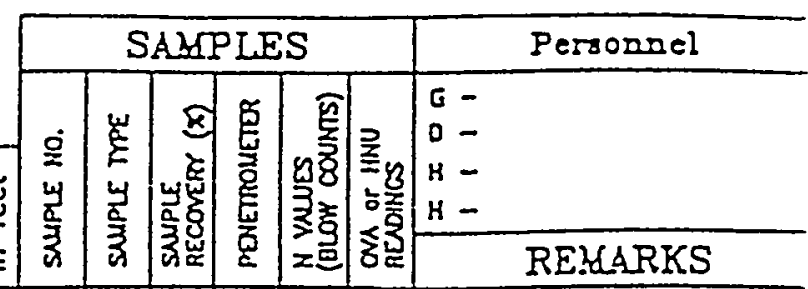

$F 630 \begin{aligned} & \text { Gray silty clay w/weathered } \\ & \text { dolomite fragments }\end{aligned}$ .614

$-$

Competent bedrock at 126'. Cored dolomite from $126^{\prime}-140^{\prime}$

$E^{110}$
Finion $6 / 13 / 97$

- 
NEW WELL AT CP-S

SPLIT SPOON CORE LOG

Location: Behind the reactor at CP-S

Date Drilled: fuqust 11, 1999

Tota! Depth: $20 \mathrm{ft}$

Water Level While orilling: Afproximately $1 \div$ Tt

8/17/8: : 10.31 it irom top oi casing

Completion: Schedule 40 PVC blant casing and sereen

$$
\begin{aligned}
& 0-10 \text { ft blank casing } \\
& \text { 10-20 ft sergen }
\end{aligned}
$$

$$
\begin{aligned}
& \text { it sement } \\
& 0-2 \text { ft bentonite } \\
& \text { 2-6 fit bo ft silica sand }
\end{aligned}
$$

Eeologis:: T.L. Fatton, ANL

Depth ( $i t)$ Description

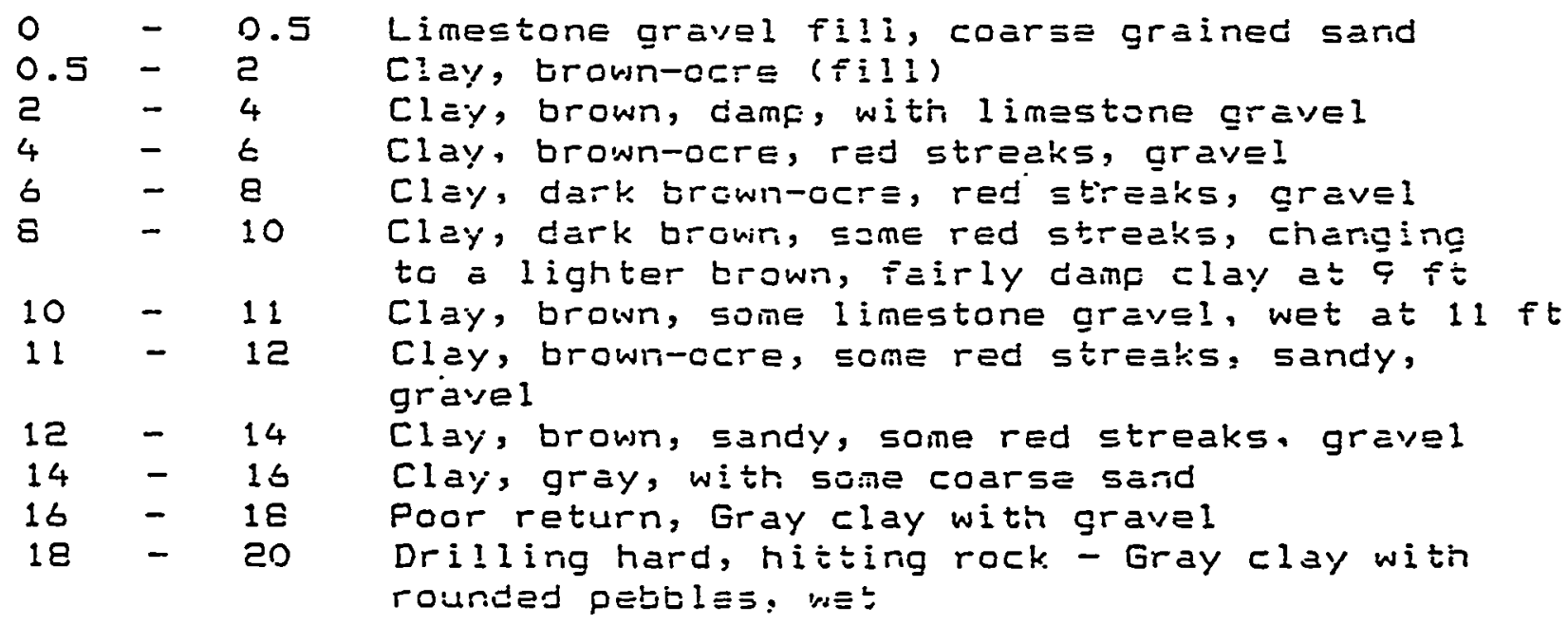




\section{NEW WELL AT CP-5 \\ STRATIGRAPHIC COLUMN}

Location: behind reactor

Date Drilled: August 11, 1989

Total Depth: $20 \mathrm{ft}$

Water Level While Drilling: approximately $14 \mathrm{ft}$

8/17/89: 10.31 ft from top of casing

Completion: Schedule 40 PVC blank casing and sereen.

$$
\begin{array}{ll}
0-10 \text { ft blank casing } & 0-2 \text { fi cement } \\
10-20 \text { ft sereen } & 2-8 \text { ft tentonite } \\
& 8-20 \mathrm{ft} \text { silica sand }
\end{array}
$$

- Geologist: T.L. Patton, ANL

Depth (ft) Description

0

0.5

Limestone gravel fill, coarsegrained sard

4

Brown clay, contairis some gravel

Brown-ocre clay, res streaking, grevel,

11 fairiy damp at $9 \mathrm{it}$, wet at 11

11 fairiy damp at $9 \mathrm{it}$, wet at 11 it

Sandy, trown to trawn-ocre clay with some

14 red streaking, gravel, wet

Gray clay with some coarse sand, gravel, and pebbles, wet

20

Totel depth 
APPENDIX C

1989 20-ft SOIL BORING SAMPLING RESULTS 
TABLE 1

SUMMARY OF RADIOLOGICAL ANALYSIS OF SOIL FROM EXISTING

MONITORING WELL 330011 IN CP-5 YARD, 1989

CP-5 YARD CHARACTERIZATION

ARGONNE NATIONAL LABORATORY

ARGONNE, ILLINOIS

(Page 1 of 1 )

\begin{tabular}{|c|c|c|c|c|c|c|c|c|c|}
\hline $\begin{array}{l}\text { SAMPLE } \\
\text { NO. }\end{array}$ & DEPTH & $\begin{array}{c}\text { WATER } \\
\text { CONTENT }\end{array}$ & $\begin{array}{l}\text { HYDROGEN-3 } \\
(\mathrm{pCi} / \mathrm{L})\end{array}$ & $\begin{array}{l}\text { HYDROGEN-3 } \\
(\mathrm{pCi} / \mathrm{g})\end{array}$ & $\begin{array}{l}\text { POTASSUIM-40 } \\
(\mathrm{pCi} / \mathrm{g})\end{array}$ & $\begin{array}{c}\text { CESIUM-137 } \\
\text { (pCi/g) }\end{array}$ & $\begin{array}{l}\text { RADIUM-226 } \\
(\mathrm{pCi} / \mathrm{g})\end{array}$ & $\begin{array}{l}\text { THORIUM-228 } \\
\text { (pCi/g) }\end{array}$ & $\begin{array}{l}\text { THORIUM-232 } \\
(\mathrm{pCi} / \mathrm{g})\end{array}$ \\
\hline $89 S 0-1360$ & $0-2^{\prime}$ & $10.3 \%$ & $128 \pm 96$ & $0.013 \pm 0.010$ & $17.87 \pm 0.74$ & $0.04 \pm 0.02$ & $1.45 \pm 0.07$ & $0.85 \pm 0.04$ & $0.63 \pm 0.09$ \\
\hline $8950-1361$ & $2-4^{\prime}$ & $10.6 \%$ & $346 \pm 100$ & $0.037 \pm 0.011$ & $17.06 \pm 0.45$ & $0.07 \pm 0.01$ & $1.32 \pm 0.04$ & $0.80 \pm 0.02$ & $0.60 \pm 0.05$ \\
\hline $89 S 0-1362$ & $4-6^{\prime}$ & $13.7 \%$ & $398 \pm 102$ & $0.055 \pm 0.014$ & $20.50 \pm 0.77$ & $<0.03$ & $1.83 \pm 0.07$ & $0.91 \pm 0.04$ & $0.80 \pm 0.10$ \\
\hline $8950-1363$ & $6-8^{\prime}$ & $14.5 \%$ & $386 \pm 101$ & $0.056 \pm 0.015$ & $19.10 \pm 0.76$ & $0.08 \pm 0.02$ & $1.20 \pm 0.06$ & $0.94 \pm 0.04$ & $0.66 \pm 0.09$ \\
\hline $89 S 0-1364$ & $8-10^{\prime}$ & $14.5 \%$ & $850 \pm 110$ & $0.123 \pm 0.016$ & $19.63 \pm 0.79$ & $<0.03$ & $1.37 \pm 0.07$ & $0.94 \pm 0.04$ & $0.75 \pm 0.09$ \\
\hline $89 S 0-1365$ & 10-12' & $12.7 \%$ & $1.40 \times 10^{4} \pm 258$ & $1.778 \pm 0.033$ & $19.68 \pm 0.76$ & $<0.03$ & $1.22 \pm 0.06$ & $0.73 \pm 0.04$ & $0.70 \pm 0.09$ \\
\hline $89 S 0-1366$ & $12-14^{\prime}$ & $12.5 \%$ & $1.61 \times 10^{4} \pm 275$ & $2.020 \pm 0.034$ & $19.33 \pm 0.76$ & $<0.03$ & $1.30 \pm 0.07$ & $0.77 \pm 0.04$ & $0.69 \pm 0.09$ \\
\hline $89 S 0-1367$ & 14-16' & $15.3 \%$ & $1.90 \times 10^{4} \pm 297$ & $2.915 \pm 0.045$ & $20.09 \pm 0.79$ & $<0.03$ & $1.18 \pm 0.07$ & $0.88 \pm 0.04$ & $0.73 \pm 0.09$ \\
\hline $89 S 0-1368$ & $16-18^{\prime}$ & $11.0 \%$ & $1.96 \times 10^{4} \pm 400$ & $2.156 \pm 0.044$ & $21.68 \pm 1.34$ & $<0.03$ & $1.52 \pm 0.12$ & $0.93 \pm 0.07$ & $0.86 \pm 0.16$ \\
\hline $8950-1369$ & $18-20^{\prime}$ & $13.4 \%$ & $1.82 \times 10^{4} \pm 291$ & $2.439 \pm 0.038$ & $17.99 \pm 0.75$ & $<0.03$ & $1.24 \pm 0.07$ & $0.75 \pm 0.04$ & $0.63 \pm 0.09$ \\
\hline
\end{tabular}




\section{ANALYTICAL SUMMARY - SURFACE SOIL RADIOLOGICAL PARAMETERS \\ CP-5 YARD CHARACTERIZATION \\ ARGONNE NATIONAL LABORATORY \\ ARGONNE, ILLINOIS \\ (Page 1 of 4)}

\begin{tabular}{|c|c|c|c|c|}
\hline \multirow[b]{2}{*}{ Sumple ID Number } & \multicolumn{4}{|c|}{ Result +1-2-Sigma Error } \\
\hline & $\mathrm{H}-3(\mathrm{pCi} / \mathrm{L})(1)$ & Gross Alpha (pCi/g) & Gross Beta (pCi/g) & $\mathrm{K}-40(\mathrm{pCi} / \mathrm{g})$ \\
\hline SB20-0.5-1.5 & $2.75 \mathrm{E}+02+1.22 \mathrm{E}+02$ & $6.15 \mathrm{E}+00+4.06 \mathrm{E}+00$ & $2.87 \mathrm{E}+01+7.20 \mathrm{E}+\infty 0$ & $1.99 \mathrm{E}+01+2.90 \mathrm{E}+00$ \\
\hline SB01-0.5-1.5 & $3.95 \mathrm{E}+02+1.70 \mathrm{E}+02$ & $6.34 \mathrm{E}+00 \pm 4.18 \mathrm{E}+00$ & $2.28 \mathrm{E}+01+6.20 \mathrm{E}+00$ & $1.13 \mathrm{E}+01+1.90 \mathrm{E}+00$ \\
\hline SBO2-0.5-1.5 & $3.07 \mathrm{E}+02 \pm 1.65 \mathrm{E}+02$ & $7.52 \mathrm{E}+00+4.58 \mathrm{E}+00$ & $2.64 \mathrm{E}+01 \pm 6.70 \mathrm{E}+00$ & $1.50 \mathrm{E}+01+2.40 \mathrm{E}+00$ \\
\hline DUP SBO2-0.5-1.5 & $3.35 \mathrm{E}+02+1.81 \mathrm{E}+02$ & NA (2) & NA & NA \\
\hline $\mathrm{SB} 03-0.5-1.5$ & $4.06 \mathrm{E}+02+1.30 \mathrm{E}+02$ & $1.13 \mathrm{E}+01+5.40 \mathrm{E}+00$ & $2.87 \mathrm{E}+01+7.30 \mathrm{E}+00$ & $2.36 \mathrm{E}+01+3.40 \mathrm{E}+00$ \\
\hline SBO4-0.5-1.5 & $2.30 \mathrm{E}+03+3.00 \mathrm{E}+02$ & $<6.00 \mathrm{E}+00$ & $2.56 \mathrm{E}+01+6.70 \mathrm{E}+00$ & $2.08 \mathrm{E}+01+3.10 \mathrm{E}+\infty$ \\
\hline SB05-0.5-1.5 & $1.23 \mathrm{E}+03+2.00 \mathrm{E}+02$ & $<5.60 \mathrm{E}+00$ & $1.25 \mathrm{E}+01+4.40 \mathrm{E}+00$ & $8.61 E+\infty 0+1.67 E+\infty$ \\
\hline SB06-0.5-1.5 (3) & $1.51 \mathrm{E}+03+3.90 \mathrm{E}+02$ & $<5.50 \mathrm{E}+00$ & $2.80 \mathrm{E}+01+7.10 \mathrm{E}+\infty 0$ & $2.28 \mathrm{E}+01+3.00 \mathrm{E}+\infty 0$ \\
\hline SBO6-0.5-1.5D & $3.24 \mathrm{E}+03 \pm 4.30 \mathrm{E}+02$ & $8.26 \mathrm{E}+00+4.78 \mathrm{E}+00$ & $2.89 \mathrm{E}+01+7.50 \mathrm{E}+00$ & $2.40 \mathrm{E}+01+3.40 \mathrm{E}+00$ \\
\hline DUP SB06-0.5-1.5D & $\mathrm{NA}$ & $1.32 \mathrm{E}+01+5.80 \mathrm{E}+00$ & $3.03 \mathrm{E}+01+7.60 \mathrm{E}+00$ & NA \\
\hline SB07-0.5-1.5 & $6.24 \mathrm{E}+02+1.82 \mathrm{E}+02$ & $<5.50 \mathrm{E}+00$ & $1.22 \mathrm{E}+01+4.30 \mathrm{E}+\infty$ & $6.60 \mathrm{E}+00+1.30 \mathrm{E}+00$ \\
\hline SB08-0.5-1.5(3) & $2.15 \mathrm{E}+04+2.40 \mathrm{E}+03$ & $8.23 E+\infty+4.74 E+\infty 0$ & $2.48 \mathrm{E}+01+6.50 \mathrm{E}+\infty 0$ & $1.93 E+01+2.80 E+00$ \\
\hline$S B 09-0.5-1.5$ & $9.29 \mathrm{E}+02+1.69 \mathrm{E}+02$ & $<4.70 \mathrm{E}+\infty 0$ & $7.42 \mathrm{E}+\infty 0+3.75 \mathrm{E}+\infty$ & $3.92 \mathrm{E}+00+8.40 \mathrm{E}-01$ \\
\hline SB10-0.5-1.5 & $2.43 \mathrm{E}+02+1.24 \mathrm{E}+02$ & $7.69 \mathrm{E}+\infty 0+4.57 \mathrm{E}+00$ & $2.60 \mathrm{E}+01 \pm 6.70 \mathrm{E}+00$ & $2.05 \mathrm{E}+01+3.00 \mathrm{E}+00$ \\
\hline SB11-0.5-1.5 & $1.21 \mathrm{E}+03+2.20 \mathrm{E}+02$ & $8.25 \mathrm{E}+00+4.55 \mathrm{E}+00$ & $2.66 \mathrm{E}+01+6.80 \mathrm{E}+\infty$ & $1.94 \mathrm{E}+01+2.90 \mathrm{E}+00$ \\
\hline SB12-0.5-1.5 & $<3.50 \mathrm{E}+02$ & $<5.90 \mathrm{E}+\infty 0$ & $8.64 \mathrm{E}+00+3.73 \mathrm{E}+\infty 0$ & $5.63 \mathrm{E}+00+1.15 \mathrm{E}+\infty$ \\
\hline SB13-0.5-1.5 & $3.12 \mathrm{E}+02+1.33 \mathrm{E}+02$ & $<5.70 \mathrm{E}+00$ & $1.30 \mathrm{E}+01 \pm 4.70 \mathrm{E}+\infty 0$ & $2.73 \mathrm{E}+01+4.90 \mathrm{E}+00$ \\
\hline SB14-0.5-1.5 & $6.58 \mathrm{E}+02+1.75 \mathrm{E}+02$ & $<6.20 \mathrm{E}+00$ & $2.28 \mathrm{E}+01 \pm 6.20 \mathrm{E}+00$ & $6.05 \mathrm{E}+01+8.20 \mathrm{E}+00$ \\
\hline DUP SB14-0.5-1.5 & $4.98 \mathrm{E}+02+1.50 \mathrm{E}+02$ & $<5.50 \mathrm{E}+00$ & $2.21 E+01+6.00 \mathrm{E}+00$ & $2.03 E+01+3.00 E+\infty$ \\
\hline SB15-0.5-1.5 & $9.45 \mathrm{E}+02 \pm 1.70 \mathrm{E}+02$ & $8.37 \mathrm{E}+00+4.40 \mathrm{E}+00$ & $1.85 \mathrm{E}+01+5.50 \mathrm{E}+00$ & $1.55 \mathrm{E}+01 \pm 2.20 \mathrm{E}+\infty 0$ \\
\hline SB16-0.5-1.5 & $3.70 \mathrm{E}+01+1.10 \mathrm{E}+02$ & $<6.10 \mathrm{E}+00$ & $2.50 \mathrm{E}+01+6.90 \mathrm{E}+00$ & $2.21 \mathrm{E}+01+3.20 \mathrm{E}+\infty$ \\
\hline SB17-0.5-1.5 & $<2.40 \mathrm{E}+02$ & $<5.10 \mathrm{E}+00$ & $2.70 \mathrm{E}+01+6.80 \mathrm{E}+00$ & $2.18 \mathrm{E}+01+2.90 \mathrm{E}+\infty 0$ \\
\hline SB17-0.5-1.5D & $5.56 \mathrm{E}+02+1.44 \mathrm{E}+02$ & $9.37 \mathrm{E}+\infty 0+5.02 \mathrm{E}+\infty 0$ & $2.60 \mathrm{E}+01+6.80 \mathrm{E}+00$ & $1.94 \mathrm{E}+01+2.90 \mathrm{E}+\infty 0$ \\
\hline SB18-0.5-1.5 & $1.52 \mathrm{E}+03+2.50 \mathrm{E}+02$ & $9.51 \mathrm{E}+00+5.38 \mathrm{E}+00$ & $2.17 \mathrm{E}+01+5.90 \mathrm{E}+\infty 0$ & $1.63 \mathrm{E}+01+2.40 \mathrm{E}+\infty 0$ \\
\hline SB19-0.5-1.5(3) & $5.22 \mathrm{E}+03+7.30 \mathrm{E}+02$ & $6.01 \mathrm{E}+\infty \pm+4.35 \mathrm{E}+\infty 0$ & $1.91 \mathrm{E}+01+5.50 \mathrm{E}+00$ & $1.21 \mathrm{E}+01+1.80 \mathrm{E}+00$ \\
\hline SB21-0.5-1.5 & $1.54 \mathrm{E}+03+2.90 \mathrm{E}+02$ & $6.38 E+\infty 0+4.09 E+\infty 0$ & $2.63 \mathrm{E}+01+6.70 \mathrm{E}+\infty 0$ & $2.10 \mathrm{E}+01+3.20 \mathrm{E}+\infty$ \\
\hline
\end{tabular}

See page 4 for footnotes. 


\section{ANALYTICAL SUMMARY - SURFACE SOIL RADIOLOGICAL PARAMETERS \\ CP-5 YARD CHARACTERIZATION \\ ARGONNE NATIONAL LABORATORY \\ ARGONNE, ILLINOIS \\ (Page 2 of 4)}

\begin{tabular}{|c|c|c|c|c|c|c|c|}
\hline & \multicolumn{7}{|c|}{ Result +1-2-Sigma Error } \\
\hline Sumple D Number & \multicolumn{2}{|c|}{$\mathrm{RA}-226(\mathrm{pCi} / \mathrm{g})$} & \multicolumn{2}{|c|}{ RA-228 (pCi/g) } & $\mathrm{CS}-137(\mathrm{pCi} / \mathrm{g})$ & \multirow{2}{*}{\multicolumn{2}{|c|}{ 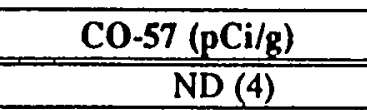 }} \\
\hline SB20-0.5-1.5 & $1.43 \mathrm{E}+00$ & $+2.30 \mathrm{E}-01$ & $1.01 \mathrm{E}+00$ & $3.10 \mathrm{E}-01$ & $<7.80 \mathrm{E}-02$ & & \\
\hline$S B 01-0.5-1.5$ & $6.74 \mathrm{E}-01$ & $\pm 1.46 \mathrm{E}-01$ & $5.26 \mathrm{E}-01$ & $2.38 \mathrm{E}-01$ & $5.82 \mathrm{E}-01+1.15 \mathrm{E}-01$ & $\mathbf{N}$ & $\mathrm{D}$ \\
\hline$S B 02-0.5-1.5$ & $1.21 \mathrm{E}+\infty 0$ & $\pm 2.10 \mathrm{E}-01$ & $9.48 \mathrm{E}-01$ & $3.14 \mathrm{E}-01$ & $5.00 \mathrm{E}-01+1.14 \mathrm{E}-01$ & $\mathrm{~N}$ & $\mathrm{D}$ \\
\hline DUP SB02-0.5-1.5 & \multicolumn{2}{|c|}{ NA } & \multicolumn{2}{|c|}{ NA } & NA & \multicolumn{2}{|c|}{ ND } \\
\hline SB03-0.5-1.5 & $1.64 \mathrm{E}+00$ & $+2.60 \mathrm{E}-01$ & \multicolumn{2}{|c|}{$6.07 \mathrm{E}-01+2.85 \mathrm{E}-01$} & $\begin{array}{l}\text { NA } \\
-01\end{array}$ & \multicolumn{2}{|c|}{ ND } \\
\hline SB04-0.5-1.5 & $1.29 \mathrm{E}+\infty$ & $\pm \quad 2.30 \mathrm{E}-01$ & $9.32 \mathrm{E}-01$ & $3.13 \mathrm{E}-01$ & $6.57 \mathrm{E}-02 \pm 6.01 \mathrm{E}-02$ & \multicolumn{2}{|c|}{ ND } \\
\hline SB05-0.5-1.5 & $7.30 \mathrm{E}-01$ & $\pm 1.59 \mathrm{E}-01$ & $4.78 \mathrm{E}-01$ & $2.60 \mathrm{E}-01$ & $4.42 \mathrm{E}-01+1.04 \mathrm{E}-01$ & $5.52 \mathrm{E}-02 \pm$ & $2.22 \mathrm{E}-02$ \\
\hline SB06-0.5-1.5(3) & $1.17 \mathrm{E}+\infty$ & $\pm 1.80 \mathrm{E}-01$ & $1.08 \mathrm{E}+00$ & $2.60 \mathrm{E}-01$ & $<6.40 \mathrm{E}-02$ & $\mathbf{N}$ & $\mathrm{D}$ \\
\hline SBO6-0.5-1.5D & $1.47 \mathrm{E}+\infty$ & $\pm \quad 2.30 \mathrm{E}-01$ & $1.30 \mathrm{E}+00$ & $3.40 \mathrm{E}-01$ & $<1.10 \mathrm{E}-01$ & $\mathbf{N}$ & $\mathrm{D}$ \\
\hline DUP SB06-0.5-1.5D & \multicolumn{2}{|c|}{ NA } & \multicolumn{2}{|c|}{ NA } & NA & \multicolumn{2}{|c|}{ ND } \\
\hline SB07-0.5-1.5 & $3.24 \mathrm{E}-01$ & $\pm 9.50 \mathrm{E}-02$ & $2.37 \mathrm{E}-01$ & $1.80 \mathrm{E}-01$ & $2.10 \mathrm{E}-01 \pm 6.50 \mathrm{E}-02$ & \multicolumn{2}{|c|}{ ND } \\
\hline SB08-0.5-1.5(3) & $1.26 \mathrm{E}+00$ & $\pm 2.10 \mathrm{E}-01$ & $9.99 \mathrm{E}-01$ & $3.09 \mathrm{E}-01$ & $<9.00 \mathrm{E}-02$ & \multicolumn{2}{|c|}{ ND } \\
\hline SB09-0.5-1.5 & $1.78 \mathrm{E}-01$ & $\pm 6.90 \mathrm{E}-02$ & $<\quad 1.30 \mathrm{E}-01$ & & $2.55 \mathrm{E}-01+5.60 \mathrm{E}-02$ & \multicolumn{2}{|c|}{ ND } \\
\hline SB10-0.5-1.5 & $1.30 \mathrm{E}+\infty$ & $\pm 2.10 \mathrm{E}-01$ & $9.49 \mathrm{E}-01$ & $2.96 \mathrm{E}-01$ & $<1.10 \mathrm{E}-01$ & \multicolumn{2}{|c|}{ ND } \\
\hline SB11-0.5-1.5 & $1.49 \mathrm{E}+\infty 0$ & $\pm 2.30 \mathrm{E}-01$ & $1.12 E+00$ & $3.20 \mathrm{E}-01$ & $<9.50 \mathrm{E}-02$ & \multicolumn{2}{|c|}{ ND } \\
\hline SB12-0.5-1.5 & $3.40 \mathrm{E}-01$ & $\pm 9.70 \mathrm{E}-02$ & $2.42 \mathrm{E}-01$ & $1.68 \mathrm{E}-01$ & $8.00 \mathrm{E}-01 \pm 1.29 \mathrm{E}-01$ & \multicolumn{2}{|c|}{ ND } \\
\hline SB13-0.5-1.5 & $2.09 \mathrm{E}+\infty$ & $\pm 4.80 \mathrm{E}-01$ & $1.31 \mathrm{E}+00$ & $7.00 \mathrm{E}-01$ & $8.64 \mathrm{E}+00+1.09 \mathrm{E}+\infty 0$ & \multicolumn{2}{|c|}{ ND } \\
\hline SB14-0.5-1.5 & $3.31 \mathrm{E}+00$ & $\pm \quad 5.20 \mathrm{E}-01$ & $2.51 \mathrm{E}+\infty 0$ & $7.10 \mathrm{E}-01$ & $<2.20 \mathrm{E}-01$ & \multicolumn{2}{|c|}{ ND } \\
\hline DUP SB14-0.5-1.5 & $1.04 \mathrm{E}+\infty=$ & $\pm 2.00 \mathrm{E}-01$ & $1.03 \mathrm{E}+00$ & $3.30 \mathrm{E}-01$ & $<1.00 \mathrm{E}-01$ & \multicolumn{2}{|c|}{ ND } \\
\hline SB15-0.5-1.5 & $1.07 \mathrm{E}+\infty$ & $\pm 1.70 \mathrm{E}-01$ & $1.04 \mathrm{E}+00$ & $2.60 \mathrm{E}-01$ & $1.91 \mathrm{E}-01 \pm 6.20 \mathrm{E}-02$ & \multicolumn{2}{|c|}{ ND } \\
\hline SB16-0.5-1.5 & $1.77 \mathrm{E}+\infty$ & $\pm 2.70 \mathrm{E}-01$ & $8.73 \mathrm{E}-01$ & $3.24 \mathrm{E}-01$ & $<9.90 \mathrm{E}-02$ & \multicolumn{2}{|c|}{ ND } \\
\hline SB17-0.5-1.5 & $1.52 \mathrm{E}+\infty 0$ & $\pm 2.20 \mathrm{E}-01$ & $9.32 \mathrm{E}-01$ & $2.69 \mathrm{E}-01$ & $<7.60 \mathrm{E}-02$ & \multicolumn{2}{|c|}{ ND } \\
\hline SB17-0.5-1.5D & $1.47 \mathrm{E}+\infty 0$ & $\pm 2.30 \mathrm{E}-01$ & $1.07 \mathrm{E}+00$ & $3.30 \mathrm{E}-01$ & $<\quad 1.00 \mathrm{E}-01$ & \multicolumn{2}{|c|}{ ND } \\
\hline SB18-0.5-1.5 & $1.07 \mathrm{E}+\infty$ & $\pm 1.80 \mathrm{E}-01$ & $8.67 \mathrm{E}-01$ & $2.91 \mathrm{E}-01$ & $4.70 \mathrm{E}-01+1.04 \mathrm{E}-01$ & $2.03 E-01+$ & $3.70 \mathrm{E}-02$ \\
\hline SB19-0.5-1.5(3) & $8.94 \mathrm{E}-01$ & $\pm 1.45 \mathrm{E}-01$ & $6.31 \mathrm{E}-01$ & $2.11 \mathrm{E}-01$ & $1.18 \mathrm{E}+00 \pm 1.60 \mathrm{E}-01$ & $N$ & D \\
\hline SB21-0.5-1.5 & $1.67 \mathrm{E}+00$ & $\pm 2.60 \mathrm{E}-01$ & $9.68 \mathrm{E}-01$ & $3.50 \mathrm{E}-01$ & $1.70 \mathrm{E}-01+8.60 \mathrm{E}-02$ & $\mathrm{~N}$ & D \\
\hline
\end{tabular}

\section{See page 4 for footnotes.}




\section{ANALYTICAL SUMMARY - SURFACE SOIL RADIOLOGICAL PARAMETERS \\ CP-5 YARD CHARACTERIZATION \\ ARGONNE NATIONAL LABORATORY \\ ARGONNE, ILLINOIS \\ (Page 3 of 4)}

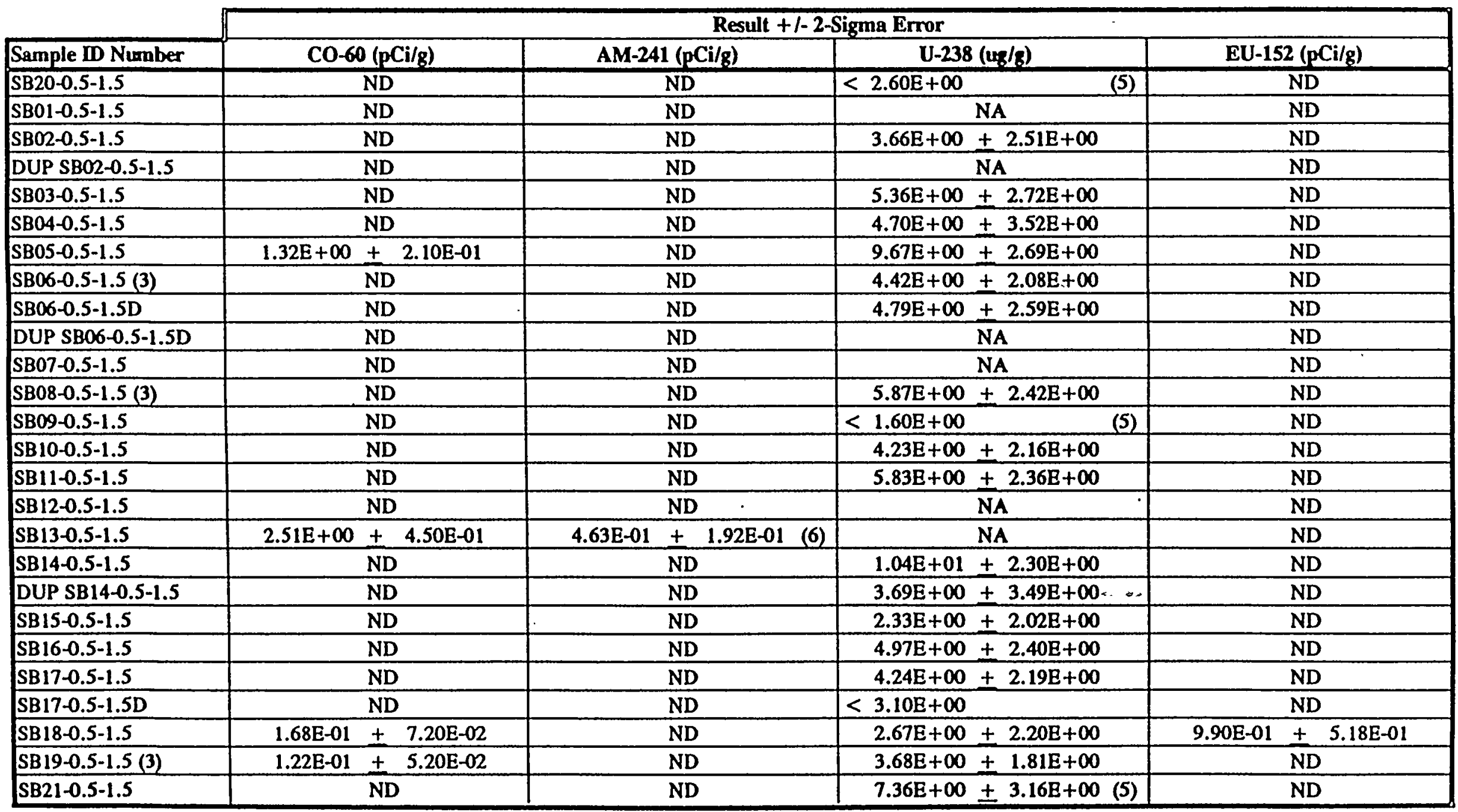

See page 4 for footnotes. 


\section{ANALYTICAL SUMMARY - SURFACE SOIL RADIOLOGICAL PARAMETERS \\ CP-5 YARD CHARACTERIZATION \\ ARGONNE NATIONAL LABORATORY \\ ARGONNE, ILLINOIS \\ (Page 4 of 4)}

(1) Tritium (H-3) analyses are performed on the moisture present in the soil which is distilled from the sample and counted on a liquid scintillation counter; therefore, results are reported in $\mathrm{pCi} / \mathrm{L}$.

(2) $\quad \mathrm{NA}=$ Not Analyzod

(3) For these tritium samples, the count rates woro inconsistent indicating possible matrix interforenco. Theroforo, only tho first count was used to calculato the activity.

(4) ND $=$ Not Detected (the analysis did not detect the parameter and, therefore, no result was indicated).

(5) Parameter is U-Total.

(6) The gamma spectrum for this sample showed a peak at $0.059 \mathrm{Mev}$ which was identified by the gamma system software library as Am-241. Th-232 also has a low abundance peak at the samo energy. Since both radioisotopes are single gamma line isotopes, it is impossible to determine by gamma spectroscopy which isotope is responsible for this peak. 


\section{ANALYTICAL SUMMARY - SUBSURFACE SOIL RADIOLOGICAL PARAMETERS \\ CP-5 YARD CHARACTERIZATION \\ ARGONNE NATIONAL LABORATORY \\ ARGONNE, ILLINOIS \\ (Page 1 of 3)}

\begin{tabular}{|c|c|c|c|c|}
\hline & \multicolumn{4}{|c|}{ Result +1-2-Sigma Error } \\
\hline Sumple ID Number & $\mathrm{H}-3$ (pCi/L) (1) & Grass Alpha (pCi/g) & Gross Beta (pCi/g) & $\mathrm{K}-40(\mathrm{pCi} / \mathrm{g})$ \\
\hline SB20-6.0-8.0 & $6.27 \mathrm{E}+02 \pm 1.45 \mathrm{E}+02$ & $<5.30 \mathrm{E}+00$ & $2.63 \mathrm{E}+01 \pm 6.90 \mathrm{E}+00$ & $2.18 \mathrm{E}+01+3.10 \mathrm{E}+00$ \\
\hline SB01-8.0-10.0 & $8.88 \mathrm{E}+03+9.70 \mathrm{E}+02$ & $1.08 \mathrm{E}+01+5.40 \mathrm{E}+00$ & $2.82 \mathrm{E}+01+7.10 \mathrm{E}+\infty 0$ & $2.04 \mathrm{E}+01+2.90 \mathrm{E}+00$ \\
\hline DUP SB01-8.0-10.0 & NA (2) & NA & $\mathrm{NA}$ & $2.19 \mathrm{E}+01+2.90 \mathrm{E}+00$ \\
\hline SBO2-8.0-10.0 & $6.41 E+03+7.10 \mathrm{E}+02$ & $8.43 \mathrm{E}+00+4.54 \mathrm{E}+00$ & $2.59 \mathrm{E}+01+6.70 \mathrm{E}+\infty 0$ & $2.16 \mathrm{E}+01+3.00 \mathrm{E}+00$ \\
\hline SB03-8.0-10.0 & $1.07 \mathrm{E}+05+1.10 \mathrm{E}+04$ & $5.24 \mathrm{E}+00+3.78 \mathrm{E}+00$ & $2.69 \mathrm{E}+01 \pm 6.90 \mathrm{E}+00$ & $2.12 \mathrm{E}+01+3.20 \mathrm{E}+00$ \\
\hline SB03-8.0-10.0D & $7.98 \mathrm{E}+04+8.10 \mathrm{E}+03$ & $1.03 \mathrm{E}+01 \pm 4.70 \mathrm{E}+00$ & $2.71 \mathrm{E}+01+7.10 \mathrm{E}+00$ & $2.28 \mathrm{E}+01+3.30 \mathrm{E}+00$ \\
\hline SBO4-8.0-10.0 & $5.14 \mathrm{E}+04+5.20 \mathrm{E}+03$ & $<6.60 \mathrm{E}+\infty 0$ & $2.62 \mathrm{E}+01+6.80 \mathrm{E}+00$ & $2.36 \mathrm{E}+01+3.60 \mathrm{E}+00$ \\
\hline SB05-8.0-10.0 & $1.42 \mathrm{E}+05+1.40 \mathrm{E}+04$ & $8.78 \mathrm{E}+00 \pm 4.83 \mathrm{E}+00$ & $2.58 \mathrm{E}+01+6.80 \mathrm{E}+00$ & $2.71 \mathrm{E}+01+3.90 \mathrm{E}+00$ \\
\hline SB06-6.0-8.0 & $6.13 \mathrm{E}+03+7.00 \mathrm{E}+02$ & $<6.00 \mathrm{E}+\infty$ & $2.60 \mathrm{E}+01+6.70 \mathrm{E}+00$ & $2.43 \mathrm{E}+01+3.50 \mathrm{E}+00$ \\
\hline SB07-4.0-6.0 & $5.82 \mathrm{E}+02+1.79 \mathrm{E}+02$ & $8.48 E+\infty+4.46 E+\infty 0$ & $2.34 \mathrm{E}+01+6.50 \mathrm{E}+00$ & $1.29 \mathrm{E}+01+1.80 \mathrm{E}+00$ \\
\hline SB07-4.0-6.0D & $9.36 \mathrm{E}+02+2.25 \mathrm{E}+02$ & $<5.10 \mathrm{E}+\infty 0$ & $1.50 \mathrm{E}+01+4.90 \mathrm{E}+00$ & $1.70 \mathrm{E}+01+2.50 \mathrm{E}+00$ \\
\hline DUP SB07-4.0-6.0 & NA & NA & $\mathrm{NA}$ & $1.49 \mathrm{E}+01+2.20 \mathrm{E}+\infty 0$ \\
\hline SBO8-4.0-6.0 & $3.18 \mathrm{E}+03+4.20 \mathrm{E}+02$ & $8.30 \mathrm{E}+\infty 0+4.91 \mathrm{E}+00$ & $3.05 \mathrm{E}+01 \pm 7.80 \mathrm{E}+00$ & $2.03 \mathrm{E}+01+3.10 \mathrm{E}+\infty 0$ \\
\hline SBO9-8.0-10.0 & $7.34 \mathrm{E}+03+7.90 \mathrm{E}+02$ & $<5.60 \mathrm{E}+\infty 0$ & $2.86 \mathrm{E}+01 \pm 7.30 \mathrm{E}+\infty 0$ & $2.20 \mathrm{E}+01+3.20 \mathrm{E}+00$ \\
\hline SB10-2.0-4.0 (3) & $9.33 \mathrm{E}+02+2.75 \mathrm{E}+02$ & $6.12 \mathrm{E}+\infty 0+4.43 \mathrm{E}+\infty 0$ & $2.83 \mathrm{E}+01+7.30 \mathrm{E}+\infty 0$ & $2.09 \mathrm{E}+01+2.80 \mathrm{E}+00$ \\
\hline DUP SB10-2.0-4.0 & NA & $7.10 \mathrm{E}+\infty 0+4.60 \mathrm{E}+00$ & $2.67 \mathrm{E}+01+6.90 \mathrm{E}+00$ & $2.16 \mathrm{E}+01+3.00 \mathrm{E}+00$ \\
\hline SB11-2.0-4.0 & $6.16 \mathrm{E}+02+1.81 \mathrm{E}+02$ & $6.10 \mathrm{E}+\infty 0+4.42 \mathrm{E}+\infty 0$ & $8.77 \mathrm{E}+\infty 0+3.87 \mathrm{E}+\infty 0$ & $2.48 \mathrm{E}+01+3.30 \mathrm{E}+\infty 0$ \\
\hline SB 12-4.0-6.0 & $<3.50 \mathrm{E}+02$ & $7.62 \mathrm{E}+\infty 0 \pm 4.74 \mathrm{E}+00$ & $3.11 \mathrm{E}+01+7.60 \mathrm{E}+\infty 0$ & $2.04 \mathrm{E}+01+3.00 \mathrm{E}+00$ \\
\hline SB13-8.0-10.0 & $1.99 \mathrm{E}+04+2.10 \mathrm{E}+03$ & $<5.90 \mathrm{E}+00$ & $2.16 \mathrm{E}+01+5.90 \mathrm{E}+00$ & $2.14 \mathrm{E}+01+3.00 \mathrm{E}+\infty$ \\
\hline SB 14-6.0-8.0 & $1.61 \mathrm{E}+02+1.24 \mathrm{E}+02$ & $<5.70 \mathrm{E}+00$ & $2.68 \mathrm{E}+01+6.80 \mathrm{E}+\infty 0$ & $2.34 \mathrm{E}+01+3.10 \mathrm{E}+00$ \\
\hline SB15-2.0-4.0 & $5.87 \mathrm{E}+03+6.40 \mathrm{E}+02$ & $7.62 \mathrm{E}+00+4.32 \mathrm{E}+00$ & $2.90 \mathrm{E}+01+7.30 \mathrm{E}+\infty 0$ & $2.10 \mathrm{E}+01+3.10 \mathrm{E}+\infty 0$ \\
\hline SB16-6.0-8.0 & $8.99 \mathrm{E}+03+9.50 \mathrm{E}+02$ & $7.64 \mathrm{E}+00 \pm 4.44 \mathrm{E}+\infty 0$ & $2.17 \mathrm{E}+01+6.00 \mathrm{E}+00$ & $2.37 \mathrm{E}+01+3.10 \mathrm{E}+\infty 0$ \\
\hline SB17-6.0-8.0 & $1.36 \mathrm{E}+03 \pm 2.10 \mathrm{E}+02$ & $<5.20 \mathrm{E}+\infty 0$ & $2.66 \mathrm{E}+01 \pm 6.80 \mathrm{E}+00$ & $2.23 \mathrm{E}+01+3.20 \mathrm{E}+\infty 0$ \\
\hline SB18-6.0-8.0 & $1.67 \mathrm{E}+03+2.90 \mathrm{E}+02$ & $9.39 \mathrm{E}+\infty 0+4.83 \mathrm{E}+00$ & $2.83 \mathrm{E}+01+7.00 \mathrm{E}+00$ & $2.21 \mathrm{E}+01+3.20 \mathrm{E}+\infty 0$ \\
\hline DUP SB18-6.0-8.0 & $5.07 \mathrm{E}+03+6.00 \mathrm{E}+02$ & NA & NA & NA \\
\hline SB19-6.0-8.0 & $<3.50 \mathrm{E}+02$ & $6.60 \mathrm{E}+\infty 0+4.42 \mathrm{E}+\infty 0$ & $2.86 \mathrm{E}+01 \pm 7.20 \mathrm{E}+00$ & $2.11 \mathrm{E}+01+3.00 \mathrm{E}+\infty 0$ \\
\hline SB21-12.0-14.0 & $<3.50 \mathrm{E}+02$ & $1.19 \mathrm{E}+01+5.70 \mathrm{E}+00$ & $2.50 \mathrm{E}+01+6.60 \mathrm{E}+00$ & $2.42 \mathrm{E}+01+3.60 \mathrm{E}+\infty 0$ \\
\hline DUP SB21-12.0-14.0 & NA & $1.17 \mathrm{E}+01+5.40 \mathrm{E}+00$ & $2.89 \mathrm{E}+01+7.40 \mathrm{E}+00$ & NA \\
\hline
\end{tabular}

Soe page 3 for footnotes. 


\section{ANALYTICAL SUMMARY - SUBSURFACE SOIL RADIOLOGICAL PARAMETERS \\ CP-5 YARD CHARACTERIZATION \\ ARGONNE NATIONAL LABORATORY \\ ARGONNE, ILLINOIS \\ (Page 2 of 3)}

\begin{tabular}{|c|c|c|c|c|}
\hline & \multicolumn{4}{|c|}{ Result +1-2-Sigma Error } \\
\hline Sample ID Number & RA-226 (pCi/g) & RA-228 (pCi/g) & CS-137 (pCi/g) & U-238 (ug/g) \\
\hline SB20-6.0-8.0 & $1.45 \mathrm{E}+00+2.20 \mathrm{E}-01$ & $5.22 \mathrm{E}-01 \pm 2.29 \mathrm{E}-01$ & $<6.90 \mathrm{E}-02$ & $2.50 \mathrm{E}+\infty 0+2.37 \mathrm{E}+\infty$ \\
\hline SBO1-8.0-10.0 & $1.72 \mathrm{E}+00 \pm 2.50 \mathrm{E}-01$ & $8.03 \mathrm{E}-01 \pm 2.50 \mathrm{E}-01$ & $<7.60 \mathrm{E}-02$ & $4.04 \mathrm{E}+00 \pm 2.07 \mathrm{E}+\infty$ \\
\hline DUP SBOI-8.0-10.0 & $1.59 \mathrm{E}+00 \pm 2.20 \mathrm{E}-01$ & $7.79 \mathrm{E}-01+2.40 \mathrm{E}-01$ & $<6.80 \mathrm{E}-02$ & $4.19 \mathrm{E}+\infty 0+2.07 \mathrm{E}+\infty 0$ \\
\hline SB02-8.0-10.0 & $1.28 \mathrm{E}+00+2.00 \mathrm{E}-01$ & $8.28 \mathrm{E}-01+2.00 \mathrm{E}-01$ & $<7.40 \mathrm{E}-02$ & $\mathrm{NA}$ \\
\hline SB03-8.0-10.0 & $1.67 \mathrm{E}+\infty 0+2.60 \mathrm{E}-01$ & $1.03 \mathrm{E}+00 \pm 3.40 \mathrm{E}-01$ & $<1.00 \mathrm{E}-01$ & $6.12 \mathrm{E}+00+2.91 \mathrm{E}+00$ \\
\hline SB03-8.0-10.0D & $1.28 \mathrm{E}+00 \pm 2.20 \mathrm{E}-01$ & $1.01 \mathrm{E}+00 \pm 3.20 \mathrm{E}-01$ & $<8.80 \mathrm{E}-02$ & $3.86 \mathrm{E}+00+2.43 \mathrm{E}+00$ \\
\hline SB04-8.0-10.0 & $1.46 \mathrm{E}+00 \pm 2.70 \mathrm{E}-01$ & $9.77 \mathrm{E}-01 \pm 3.80 \mathrm{E}-01$ & $<\quad 1.10 \mathrm{E}-01$ & $3.73 \mathrm{E}+00+4.40 \mathrm{E}+00$ \\
\hline SB05-8.0-10.0 & $1.42 \mathrm{E}+00+2.80 \mathrm{E}-01$ & $1.03 \mathrm{E}+00+3.40 \mathrm{E}-01$ & $<\quad 1.10 \mathrm{E}-01$ & $1.52 \mathrm{E}+01+3.60 \mathrm{E}+\infty$ \\
\hline$S B 06-6.0-8.0$ & $1.72 \mathrm{E}+00 \pm 2.70 \mathrm{E}-01$ & $1.26 \mathrm{E}+00 \pm 4.10 \mathrm{E}-01$ & $<9.90 \mathrm{E}-02$ & $3.70 \mathrm{E}+00 \pm 2.95 \mathrm{E}+00$ \\
\hline SB07-4.0-6.0 & $1.15 \mathrm{E}+00+1.60 \mathrm{E}-01$ & $6.85 \mathrm{E}-01+1.90 \mathrm{E}-01$ & $7.65 \mathrm{E}-02 \pm 4.38 \mathrm{E}-02$ & $3.99 \mathrm{E}+00+1.74 \mathrm{E}+00$ \\
\hline SB07-4.0-6.0D & $1.34 \mathrm{E}+00 \pm 2.00 \mathrm{E}-01$ & $9.84 \mathrm{E}-01 \pm 2.65 \mathrm{E}-01$ & $<8.70 \mathrm{E}-02$ & $5.76 \mathrm{E}+00 \pm 2.12 \mathrm{E}+00$ \\
\hline DUP SB07-4.0-6.0 & $1.18 \mathrm{E}+00 \pm 1.80 \mathrm{E}-01$ & $7.07 \mathrm{E}-01+2.59 \mathrm{E}-01$ & $8.71 \mathrm{E}-02+6.40 \mathrm{E}-02$ & $3.92 \mathrm{E}+\infty 0+1.80 \mathrm{E}+\infty 0$ \\
\hline SB08-4.0-6.0 & $1.41 \mathrm{E}+00 \pm 2.40 \mathrm{E}-01$ & $8.99 \mathrm{E}-01+3.63 \mathrm{E}-01$ & $<1.20 \mathrm{E}-01$ & $3.28 \mathrm{E}+00 \pm 2.99 \mathrm{E}+\infty 0$ \\
\hline SB09-8.0-10.0 & $1.50 \mathrm{E}+00 \pm 2.40 \mathrm{E}-01$ & $7.84 \mathrm{E}-01 \pm 2.83 \mathrm{E}-01$ & $<9.90 \mathrm{E}-02$ & $5.34 \mathrm{E}+00+2.52 \mathrm{E}+00$ \\
\hline SB10-2.0-4.0 & $1.42 \mathrm{E}+00 \pm 2.10 \mathrm{E}-01$ & $1.03 \mathrm{E}+00+2.60 \mathrm{E}-01$ & $<7.00 \mathrm{E}-02$ & $4.22 \mathrm{E}+\infty 0+2.13 \mathrm{E}+\infty 0$ \\
\hline DUP SB $10-2.0-4.0$ & $1.46 \mathrm{E}+00+2.30 \mathrm{E}-01$ & $1.11 \mathrm{E}+00+3.10 \mathrm{E}-01$ & $<9.10 \mathrm{E}-02$ & $5.06 \mathrm{E}+00+2.50 \mathrm{E}+00$ \\
\hline SB11-2.0-4.0 & $1.83 \mathrm{E}+00+2.60 \mathrm{E}-01$ & $1.09 \mathrm{E}+00 \pm 3.00 \mathrm{E}-01$ & $<7.70 \mathrm{E}-02$ & $4.69 \mathrm{E}+00+2.39 \mathrm{E}+00$ \\
\hline SB12-4.0-6.0 & $1.39 \mathrm{E}+00+2.20 \mathrm{E}-01$ & $1.07 \mathrm{E}+00+3.10 \mathrm{E}-01$ & $<9.50 \mathrm{E}-02$ & $5.34 \mathrm{E}+\infty 0+2.30 \mathrm{E}+\infty 0$ \\
\hline SB13-8.0-10.0 & $1.21 \mathrm{E}+\infty 0+1.90 \mathrm{E}-01$ & $7.09 \mathrm{E}-01 \pm 2.47 \mathrm{E}-01$ & $<7.10 \mathrm{E}-02$ & $9.09 \mathrm{E}+00+2.42 \mathrm{E}+00$ \\
\hline SB 14-6.0-8.0 & $1.37 \mathrm{E}+00+2.00 \mathrm{E}-01$ & $8.94 \mathrm{E}-01+2.53 \mathrm{E}-01$ & $<7.50 \mathrm{E}-02$ & $9.88 \mathrm{E}+00+2.31 \mathrm{E}+00$ \\
\hline SB15-2.0-4.0 & $1.40 \mathrm{E}+\infty 0 \pm 2.30 \mathrm{E}-01$ & $1.17 \mathrm{E}+00+3.50 \mathrm{E}-01$ & $<1.10 \mathrm{E}-01$ & $2.94 \mathrm{E}+00 \pm 2.52 \mathrm{E}+\infty 0$ \\
\hline SB16-6.0-8.0 & $1.38 \mathrm{E}+00+2.10 \mathrm{E}-01$ & $9.44 \mathrm{E}-01+2.64 \mathrm{E}-01$ & $<8.10 \mathrm{E}-02$ & $4.65 \mathrm{E}+00+2.29 \mathrm{E}+00$ \\
\hline SB 17-6.0-8.0 & $1.41 \mathrm{E}+00+2.30 \mathrm{E}-01$ & $8.17 \mathrm{E}-01 \pm 3.10 \mathrm{E}-01$ & $<8.50 \mathrm{E}-02$ & $5.52 \mathrm{E}+00+2.60 \mathrm{E}+00$ \\
\hline SB18-6.0-8.0 & $1.53 \mathrm{E}+00 \pm 2.40 \mathrm{E}-01$ & $1.03 \mathrm{E}+00+3.10 \mathrm{E}-01$ & $<8.90 \mathrm{E}-02$ & $4.33 \mathrm{E}+00 \pm 2.48 \mathrm{E}+\infty 0$ \\
\hline DUP SB 18-6.0-8.0 & NA & NA & NA & NA \\
\hline SB 19-6.0-8.0 & $1.17 \mathrm{E}+00+2.00 \mathrm{E}-01$ & $9.78 \mathrm{E}-01+3.24 \mathrm{E}-01$ & $<8.60 E-02$ & $3.70 \mathrm{E}+00+2.36 \mathrm{E}+\infty 0$ \\
\hline SB21-12.0-14.0 & $1.59 \mathrm{E}+00 \pm 2.70 \mathrm{E}-01$ & $1.14 \mathrm{E}+\infty 0+3.70 \mathrm{E}-01$ & $<\quad 1.00 \mathrm{E}-01$ & $5.27 \mathrm{E}+00 \pm 3.07 \mathrm{E}+00(4)$ \\
\hline DUP SB21-12.0-14.0 & NA & NA & $\begin{array}{r}\text { NA } \\
\end{array}$ & NA \\
\hline
\end{tabular}

Soe page 3 for footnotes. 


\section{ANALYTICAL SUMMARY - SUBSURFACE SOIL RADIOLOGICAL PARAMETERS \\ CP-5 YARD CHARACTERIZATION \\ ARGONNE NATIONAL LABORATORY \\ ARGONNE, ILLINOIS \\ (Page 3 of 3)}

(1) Tritium (H-3) analyses are performed on the moisture present in the soil which is distilled from the sample and counted on a liquid scintillation counter; therefore, results are reported in $\mathrm{pCi} / \mathrm{L}$.

(2) $\quad$ NA $=$ Not Analyzed

(3) Distilled water was used to increase the volume for this sample in order to perform the tritium analysis.

(4) Samplo was analyzod for total uranium (U-Total). 


\section{APPENDIX E}

RESIDENTIAL FAMILY-FARM RESRAD SUMMARY REPORT 
RESRAD, Version 5.82

Th Limit $=0.5$ year

Summary : CP-5 Residential Family-Farm Scenario
10/26/98 10:01 Page 1

Eile: CP5OSITE.RAD

Table of Contents

Part I: Mixture Sums and Single Radionuclide Guidelines

Dose Conversion Factor (and Related) Parameter Summary ... 2

Site-specific parameter summary .................. 3

Summary of pathway selections .................. 7

Contaminated zone and Total Dose Summary ............ 8

Total Dose Components

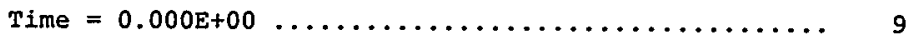

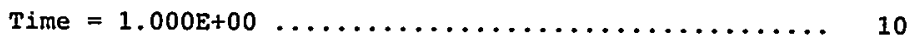

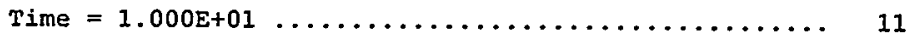

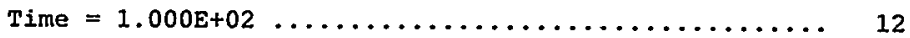

Dose/Source Ratios Sumned Over All Pathways ........... 13

Single Radionuclide Soil Guidelines ............... 13

Dose Per Nuclide Summed Over All Pathways ........... 14

Soil Concentration Per Nuclide .................. 14 
RESRAD, Version 5.82

Summary : CP-5 Residential Family-Farm Scenario
10/26/98 10:01 Page 2

File: CP5OSITE.RAD

Dose Conversion Factor (and Related) Parameter Summary

File: DOSFAC.BIN

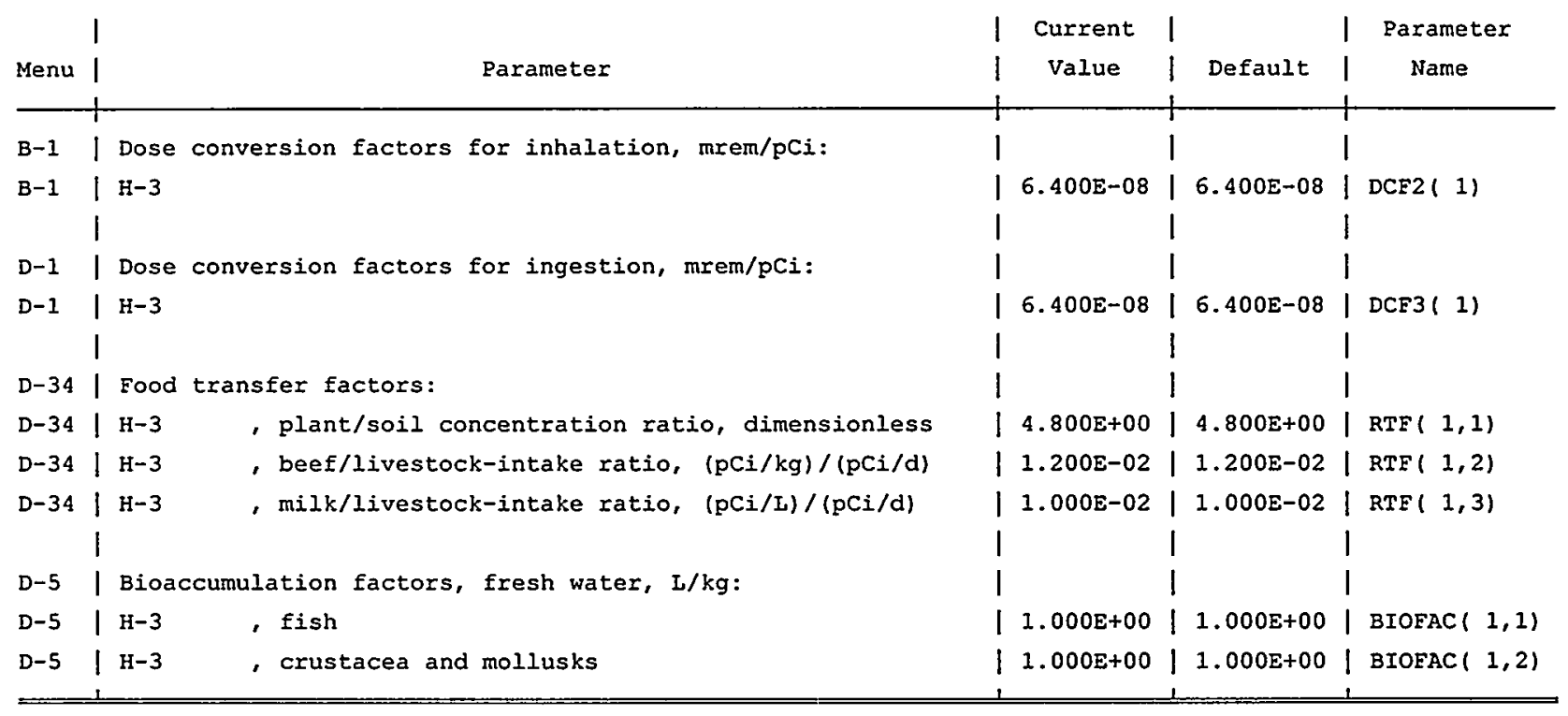


RESRAD, Version 5.82 Th Limit $=0.5$ year

Summary : CP-5 Residential Family-Earm Scenario
10/26/98 10:01 Page 3

File: CPSOSITE.RAD

Site-Specific Parameter Surimary

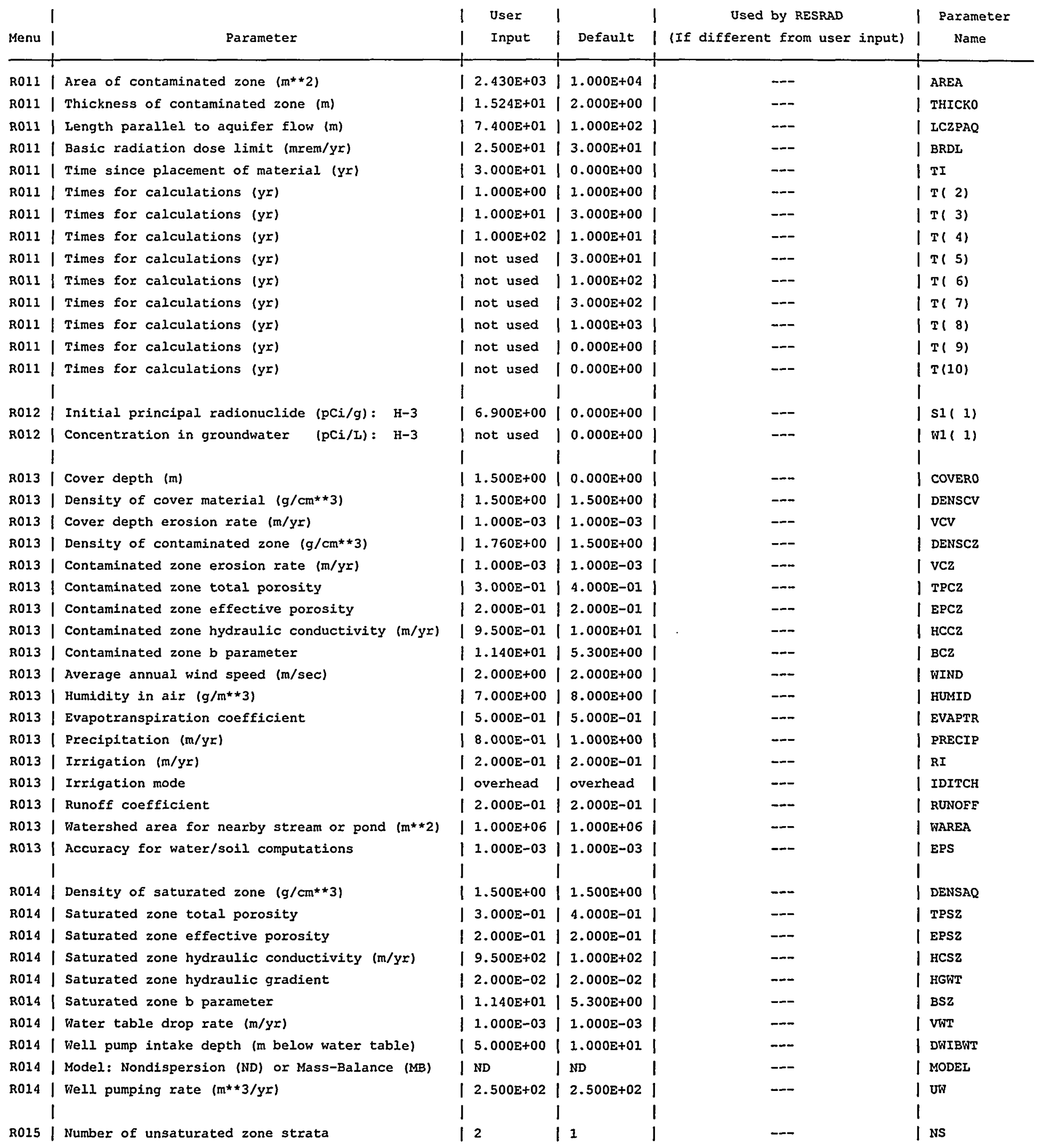


RESRAD, Version 5.82 Th Limit $=0.5$ year

Summary : CP-5 Residential Family-Farm Scenario
10/26/98 10:01 Page 4

File: CPSOSITE.RAD

Site-Specific Parameter Sumary (continued)

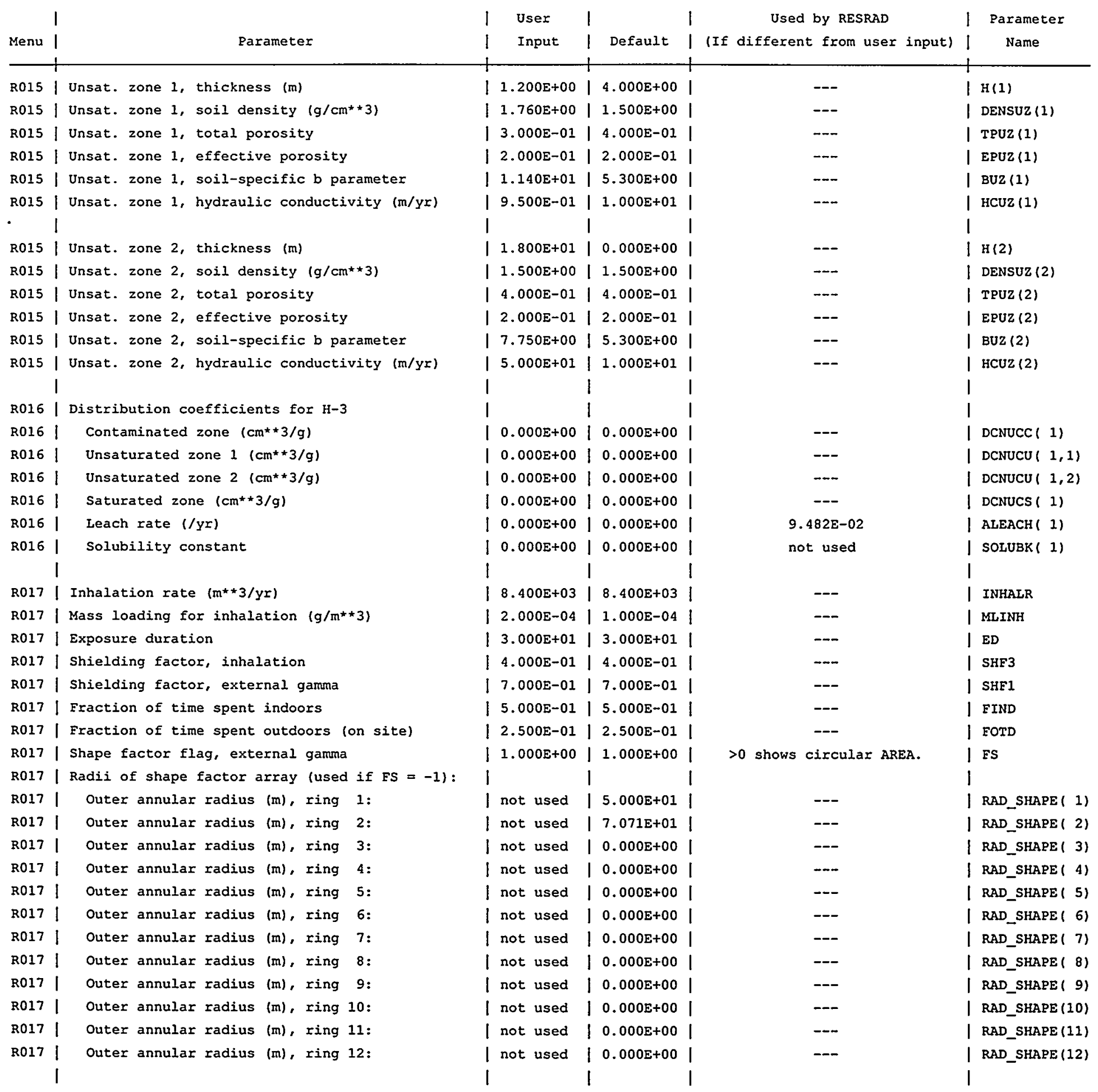


RESRAD, Version 5.82 Th Limit $=0.5$ year

Summary : CP-5 Residential Family-Farm Scenario
10/26/98 10:01 Page 5

File: CPSOSITE.RAD

Site-Specific Parameter Summary (continued)

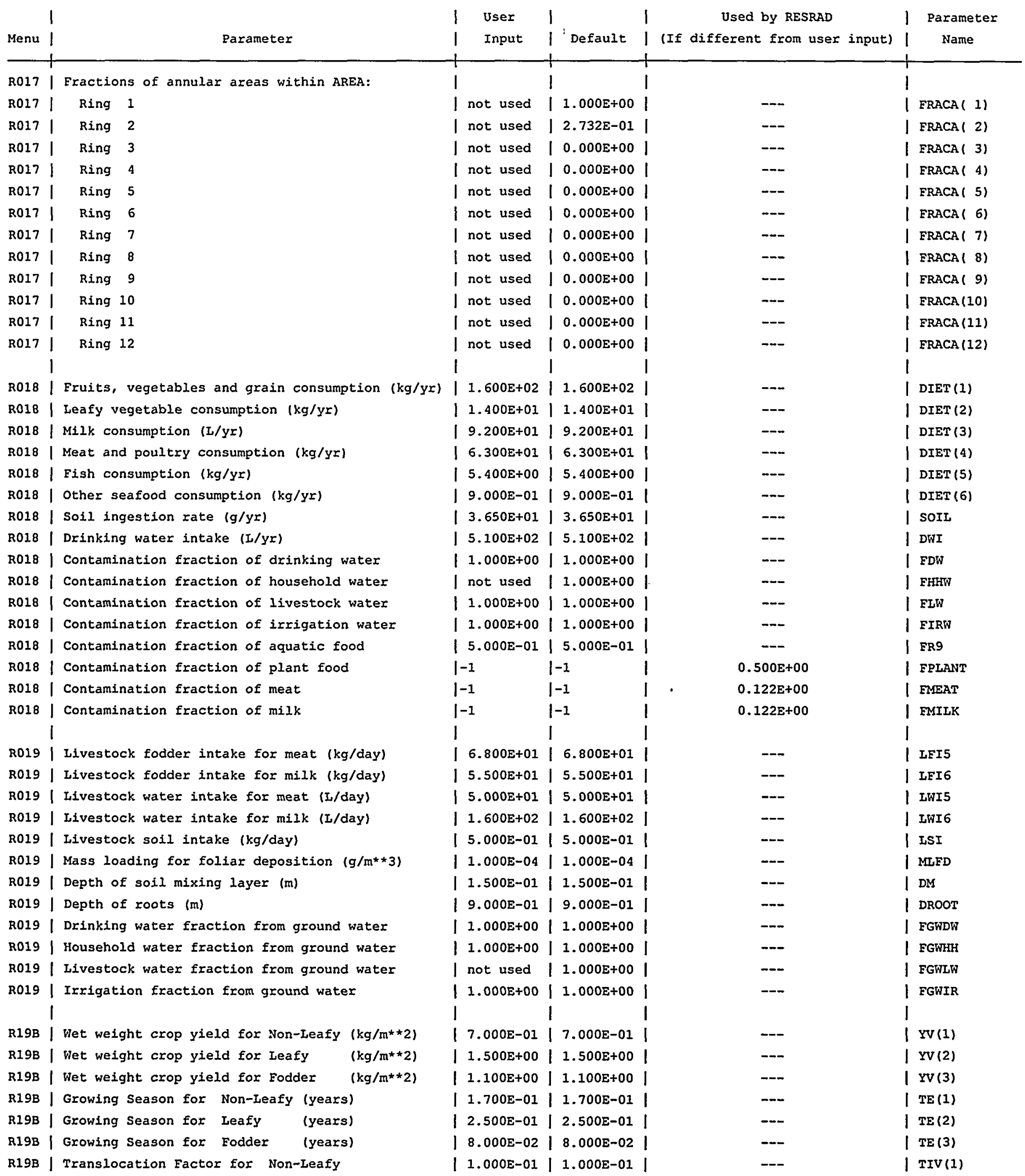


RESRAD, Version $5.82 \quad$ Th Limit $=0.5$ year

Sumary : CP-5 Residential Family-Farm Scenario
10/26/98 10:01 Page 6

File: CPSOSTTE.RAD

Site-Specific Parameter Summary (continued)

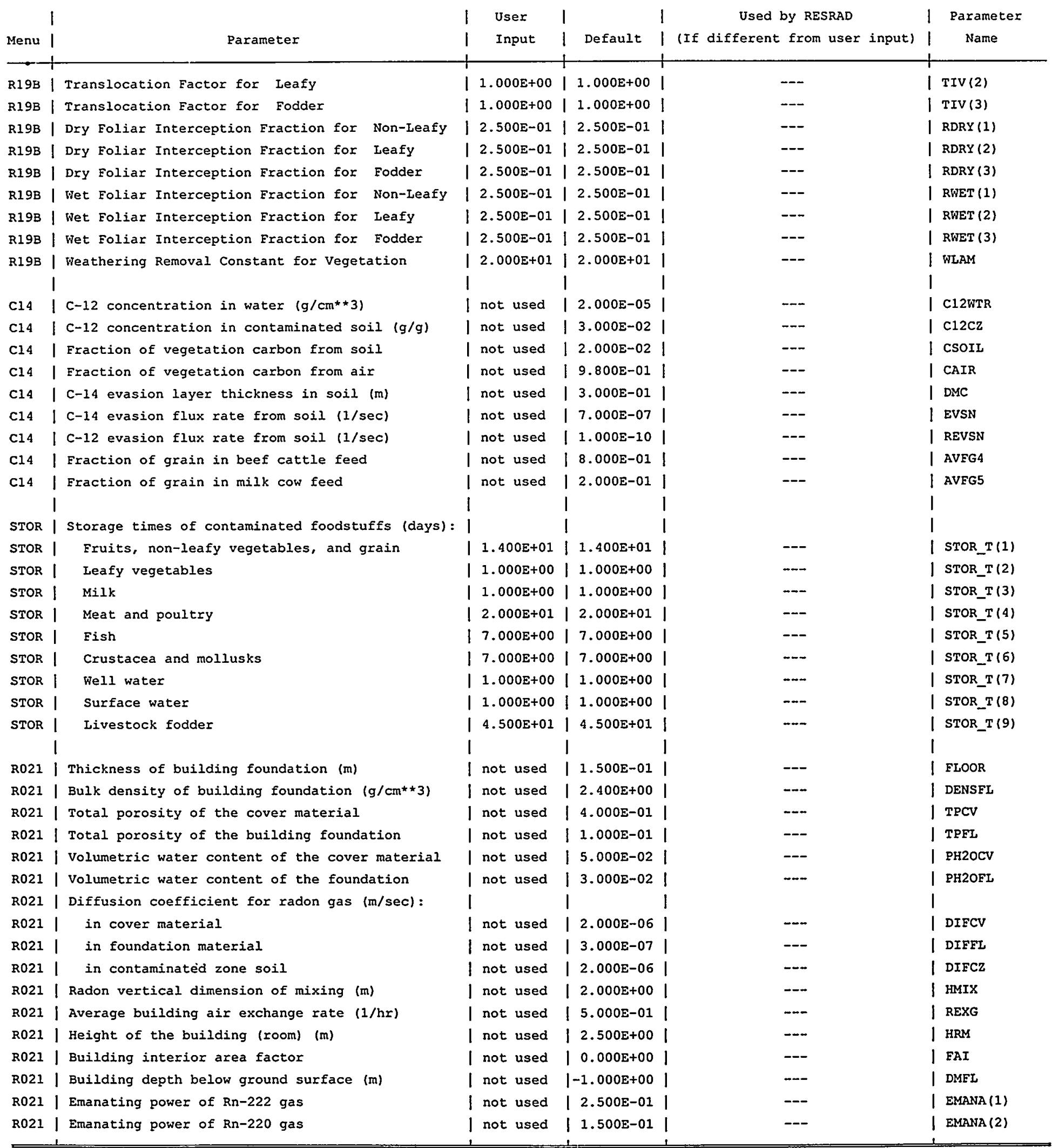


RESRAD, Version $5.82 \quad T \%$ Limit $=0.5$ year

Summary : CP-5 Residential Family-Farm Scenario
10/26/98 10:01 Page 7

File: CPSOSITE.RAD

Summary of Pathway Selections

\begin{tabular}{|c|c|}
\hline Pathway & | User Selection \\
\hline 1 -- external gamma & active \\
\hline 2 -- inhalation (w/o radon) & active \\
\hline 3 -- plant ingestion & active \\
\hline 4 - meat ingestion & active \\
\hline 5 -- milk ingestion & active \\
\hline 6 -- aquatic foods & active \\
\hline 7 -- drinking water & active \\
\hline 8 -- soil ingestion & active \\
\hline 9 -n radon & suppressed \\
\hline Find peak pathway doses & suppressed \\
\hline
\end{tabular}




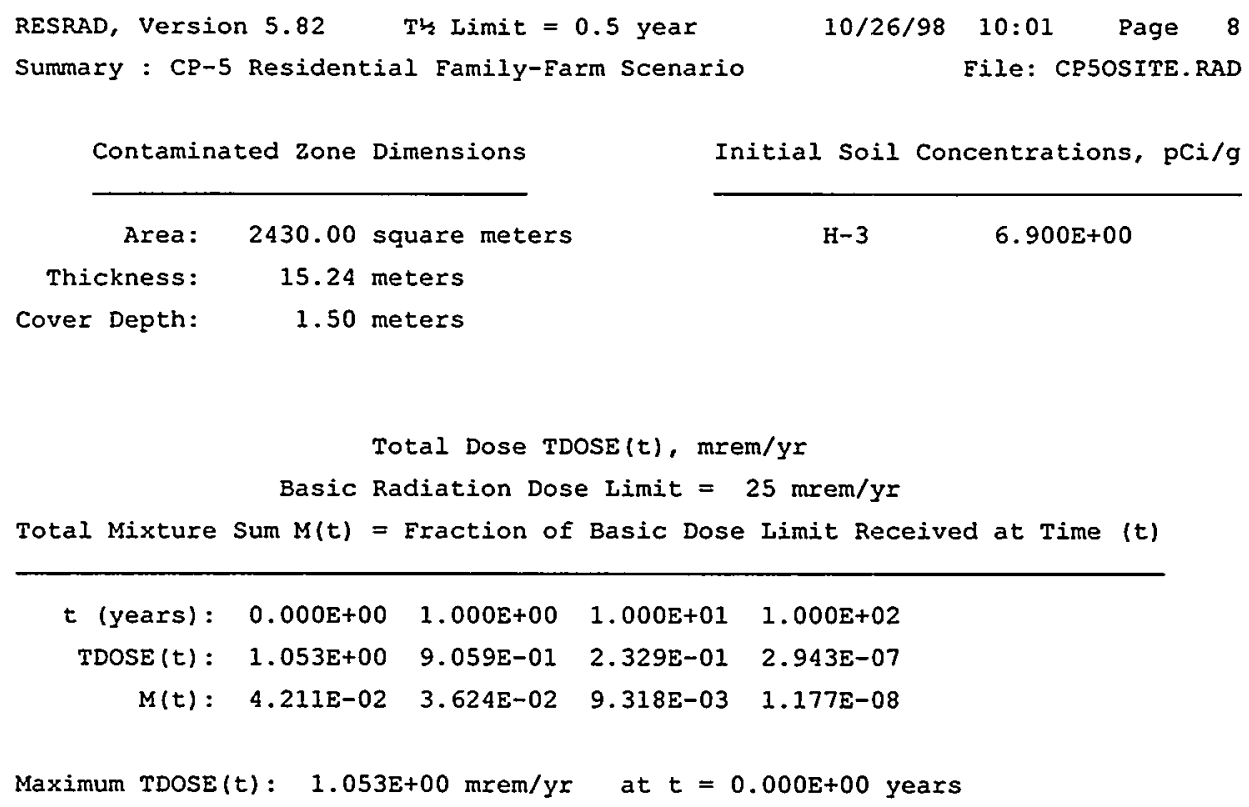

Maximum TDOSE $(t): 1.053 E+00 \mathrm{mrem} / \mathrm{yr}$ at $t=0.000 E+00$ years 
RESRAD, Version 5.82 Th Limit $=0.5$ year Summary : CP-5 Residential Family-Farm Scenario
10/26/98 10:01 Page 9

File: CPSOSITE.RAD

Total Dose Contributions TDOSE $(i, p, t)$ for Individual Radionuclides (i) and Pathways (p) As mrem/yr and Fraction of Total Dose At $t=0.000 E+00$ years

Water Independent Pathways (Inhalation excludes radon)

\begin{tabular}{|c|c|c|c|c|c|c|c|c|c|c|c|c|c|c|}
\hline \multirow{2}{*}{$\begin{array}{l}\text { Radio- } \\
\text { Nuclide }\end{array}$} & \multicolumn{2}{|c|}{ Ground } & \multicolumn{2}{|c|}{ Inhalation } & \multicolumn{2}{|c|}{ Radon } & \multicolumn{2}{|c|}{ Plant } & \multicolumn{2}{|c|}{ Meat } & \multicolumn{2}{|c|}{ Milk } & \multicolumn{2}{|c|}{ Soil } \\
\hline & mrem/yr & fract. & mrem/yr & fract. & mrem/yr & fract. & mrem/yr & Eract. & mrem/yr & fract. & mrem/yr & fract. & mrem/yr & fract. \\
\hline $\mathrm{H}-3$ & $0.000 \mathrm{E}+00$ & 0.0000 & $0.000 \mathrm{E}+00$ & 0.0000 & $0.000 \mathrm{E}+00$ & 0.0000 & $0.000 \mathrm{E}+00$ & 0.0000 & $0.000 \mathrm{E}+00$ & 0.0000 & $0.000 \mathrm{E}+00$ & 0.0000 & $0.000 \mathrm{E}+00$ & 0.0000 \\
\hline Total & $0.000 \mathrm{E}+00$ & 0.0000 & $0.000 E+00$ & 0.0000 & $0.000 \mathrm{E}+00$ & 0.0000 & $0.000 \mathrm{E}+00$ & 0.0000 & $0.000 \mathrm{E}+00$ & 0.0000 & $0.000 \mathrm{E}+00$ & 0.0000 & $0.000 E+00$ & 0.0000 \\
\hline
\end{tabular}

Total Dose Contributions TDOSE $(i, p, t)$ for Individual Radionuclides (i) and Pathways (p) As mrem/yr and Eraction of Total Dose At $t=0.000 E+00$ years

Water Dependent Pathways

\begin{tabular}{|c|c|c|c|c|c|c|c|c|c|c|c|c|c|c|}
\hline \multirow{2}{*}{$\begin{array}{l}\text { Radio- } \\
\text { Nuclide }\end{array}$} & \multicolumn{2}{|c|}{ Water } & \multicolumn{2}{|c|}{ Fish } & \multicolumn{2}{|c|}{ Radon } & \multicolumn{2}{|c|}{ Plant } & \multicolumn{2}{|c|}{ Meat } & \multicolumn{2}{|c|}{ Milk } & \multicolumn{2}{|c|}{ All Pathways* } \\
\hline & mrem/yr & fract. & mrem/yr & fract. & mrem/yr & fract. & mrem/yr & fract. & mren/yr & fract. & mrem/yr & fract. & mrem/yr & fract. \\
\hline $\mathrm{H}-3$ & $9.141 E-01$ & 0.8683 & $4.194 \mathrm{E}-05$ & 0.0000 & $0.000 \mathrm{E}+00$ & 0.0000 & $1.174 \mathrm{E}-01$ & 0.1115 & $5.776 \mathrm{E}-03$ & 0.0055 & $1.545 \mathrm{E}-02$ & 0.0147 & $1.053 E+00$ & 1.0000 \\
\hline Total & $9.141 \mathrm{E}-01$ & 0.8683 & $4.194 \mathrm{E}-05$ & 0.0000 & $0.000 \mathrm{E}+00$ & 0.0000 & $1.174 \mathrm{E}-01$ & 0.1115 & $5.776 \mathrm{E}-03$ & 0.0055 & $1.545 E-02$ & 0.0147 & $1.053 \mathrm{E}+00$ & 1.0000 \\
\hline
\end{tabular}


RESRAD, Version 5.82 TH Limit $=0.5$ year

Summary : CP-5 Residential Family-Farm Scenario
10/26/98 10:01 Page 11

File: CPSOSITE.RAD

Total Dose Contributions TDOSE $(i, p, t)$ for Individual Radionuclides ( $i$ ) and Pathways ( $p$ ) As mrem/yr and Fraction of Total Dose At $t=1.000 E+01$ years

Water Independent Pathways (Inhalation excludes radon)

\begin{tabular}{|c|c|c|c|c|c|c|c|c|c|c|c|c|c|c|}
\hline \multirow{2}{*}{$\begin{array}{l}\text { Radio- } \\
\text { Nuclide }\end{array}$} & \multicolumn{2}{|c|}{ Ground } & \multicolumn{2}{|c|}{ Inhalation } & \multicolumn{2}{|c|}{ Radon } & \multicolumn{2}{|c|}{ Plant } & \multicolumn{2}{|c|}{ Meat } & \multicolumn{2}{|c|}{ Milk } & \multicolumn{2}{|c|}{ Soil } \\
\hline & mrem/yr & Eract. & mrem/yr & fract. & mrem/yr & fract. & mrem/yr & fract. & mrem/yx & Eract. & mrem/yr & fract. & mrem/yr & fract. \\
\hline $\mathrm{H}-3$ & $0.000 E+00$ & 0.0000 & $0.000 E+00$ & 0.0000 & $0.000 E+00$ & 0.0000 & $0.000 E+00$ & 0.0000 & $0.000 \mathrm{E}+00$ & 0.0000 & $0.000 \mathrm{E}+00$ & 0.0000 & $0.000 \mathrm{E}+00$ & 0.0000 \\
\hline Total & $0.000 E+00$ & 0.0000 & $0.000 \mathrm{E}+00$ & 0.0000 & $0.000 E+00$ & 0.0000 & $0.000 \mathrm{E}+00$ & 0.0000 & $0.000 \mathrm{E}+00$ & 0.0000 & $0.000 E+00$ & 0.0000 & $0.000 E+00$ & 0.0000 \\
\hline
\end{tabular}

Total Dose Contributions TDOSE $(i, p, t)$ for Individual Radionuclides (i) and Pathways (p) As mrem/yr and Fraction of Total Dose At $t=1.000 E+01$ years

Water Dependent Pathways

\begin{tabular}{|c|c|c|c|c|c|c|c|c|c|c|c|c|c|c|}
\hline \multirow{2}{*}{$\begin{array}{l}\text { Radio- } \\
\text { Nuclide }\end{array}$} & \multicolumn{2}{|c|}{ Water } & \multicolumn{2}{|c|}{ Fish } & \multicolumn{2}{|c|}{ Radon } & \multicolumn{2}{|c|}{ Plant } & \multicolumn{2}{|c|}{ Meat } & \multicolumn{2}{|c|}{ Milk } & \multicolumn{2}{|c|}{ Al1 Pathways* } \\
\hline & mrem/yr & fract. & mrem/yr & Eract. & mrem/yr & fract. & mrem/yr & fract. & mrem/yr & fract. & mrem/yr & fract. & mrem/yr & fract. \\
\hline $\mathrm{H}-3$ & $2.022 E-01$ & 0.8679 & $9.290 \mathrm{E}-06$ & 0.0000 & $0.000 \mathrm{E}+00$ & 0.0000 & $2.604 \mathrm{E}-02$ & 0.1118 & $1.289 \mathrm{E}-03$ & 0.0055 & $3.423 \mathrm{E}-03$ & 0.0147 & $2.329 \mathrm{E}-01$ & 1.0000 \\
\hline Total & $2.022 \mathrm{E}-01$ & 0.8679 & $9.290 \mathrm{E}-06$ & 0.0000 & $0.000 \mathrm{E}+00$ & 0.0000 & $2.604 \mathrm{E}-02$ & 0.1118 & $1.289 E-03$ & 0.0055 & $3.423 E-03$ & 0.0147 & $2.329 E-01$ & 1.0000 \\
\hline
\end{tabular}




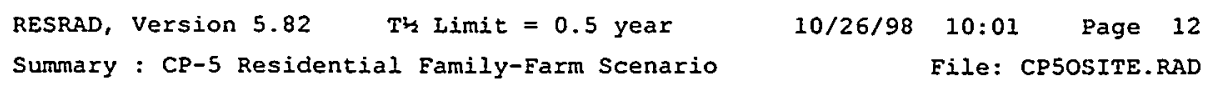


RESRAD, Version $5.82 \quad T$ Lh Limit $=0.5$ year

Sumnary : CP-5 Residential Family-Farm Scenario
10/26/98 10:01 Page 13

File: CPSOSITE.RAD

Dose/Source Ratios Summed Over All Pathways

Parent and Progeny Principal Radionuclide Contributions Indicated

Parent Product Branch DSR $(j, \mathrm{t})$ (mrem/yr)/(pCi/g)

(i) (j) Eraction* $t=0.000 E+001.000 E+001.000 E+01 \quad 1.000 E+02$

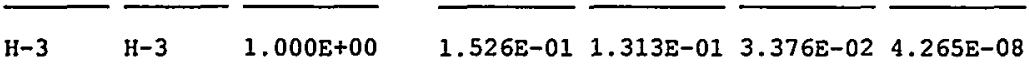

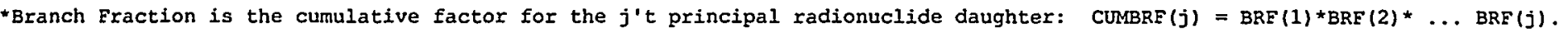
The DSR includes contributions from associated (half-life $\leq 0.5$ yr) daughters.

Single Radionuclide Soil Guidelines $G(i, t)$ in $\mathrm{pCi} / \mathrm{g}$ Basic Radiation Dose Iimit $=25 \mathrm{mrem} / \mathrm{yr}$

Nuclide

(i)

$\mathrm{H}-3$

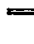

$t=$

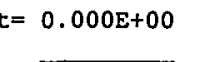

$$
1.639 \mathrm{E}+02
$$$$
1.000 \mathrm{E}+00
$$

$\overline{1.904 \mathrm{E}+02}$

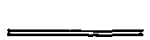

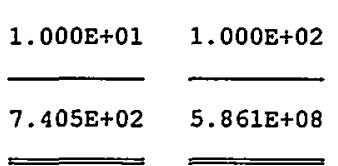




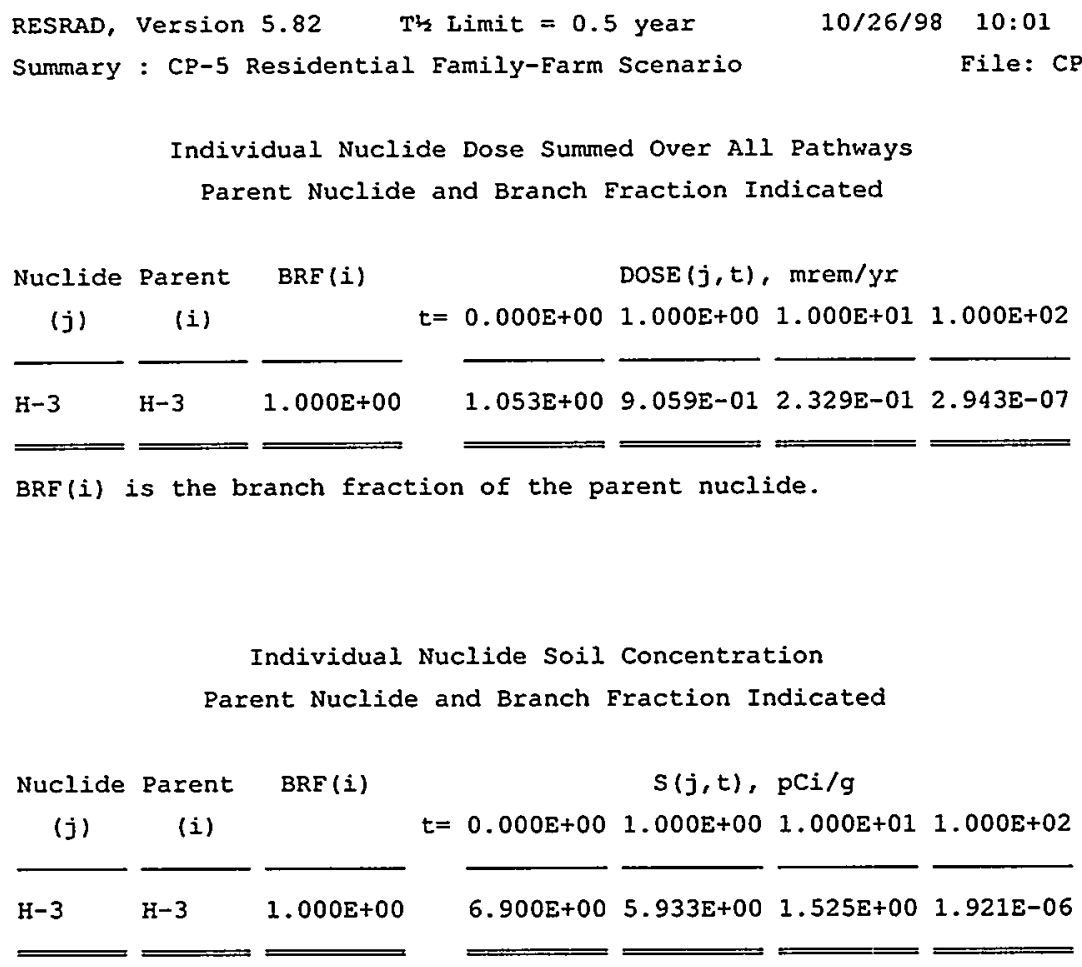

BRF(i) is the branch fraction of the parent nuclide.

Individual Nuclide Soil Concentration

Parent Nuclide and Branch Fraction Indicated

\begin{tabular}{|c|c|c|c|c|c|c|c|}
\hline $\begin{array}{c}\text { Nuclide } \\
\text { (j) }\end{array}$ & $\begin{array}{c}\text { Parent } \\
\text { (i) }\end{array}$ & $\operatorname{BRF}(i)$ & $t=$ & $0.000 \mathrm{E}+00$ & $\begin{array}{r}s(j, t), \\
1.000 E+00\end{array}$ & $\begin{array}{l}\mathrm{pCi} / \mathrm{g} \\
1.000 \mathrm{E}+01\end{array}$ & $1.000 \mathrm{E}+02$ \\
\hline $\mathrm{H}-3$ & $\mathrm{H}-3$ & $1.000 \mathrm{E}+00$ & & $6.900 \mathrm{E}+00$ & $5.933 \mathrm{E}+00$ & $1.525 E+00$ & $1.921 \mathrm{E}-06$ \\
\hline
\end{tabular}

BRF(i) is the branch fraction of the parent nuclide. 


\section{APPENDIX F}

RESIDENTIAL FAMLY-FARM RESRAD DETAILED REPORT 
RESRAD, Version 5.82 Th Limit $=0.5$ year

Detailed: CP-5 Residential Family-Farm Scenario
10/26/98 11:44 Page 1

File: CPSOSITE.RAD

\section{Table of Contents}

Part II: Source Terms, Eactors, and Parameters for Individual Pathways

Source Factors for Ingrowth and Decay

Radioactivity only ..................... 3

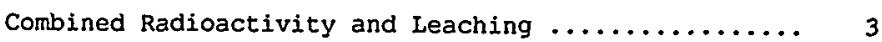

Ground Pathway

Source Term Parameters .................... 4

Time Dependence of Source Geometry .............. 4

Occupancy, Cover/Depth, and Area Factors ......... 5

Dose Conversion and Environmental Transport Eactors . 5

Dose/Source Ratios ....................... 5

Inhalation Pathway (radon excluded)

Dose/Source Ratios ........................ 6

Pathway Eactors ........................ 6

Dose Conversion and Environmental Transport Eactors . 6

Groundwater and Surface Water Pathway Segments

Transport Time Parameters for Unsaturated Zone Strata 7

Dilution Factor and Rise Time Parameters for

Nondispersion (ND) Model .............. 8

Primary Parameters Used to Calculate Ratios ........ 8

Water/Soil Concentration Ratios ................ 9 
RESRAD, Version $5.82 \quad T^{1 / 2}$ Iimit $=0.5$ year Detailed: CP-5 Residential Family-Farm Scenario
$10 / 26 / 98 \quad 11: 44 \quad$ Page 2

File: CP5OSITE.RAD

Table of Contents (cont.)

Part II: Source Terms, Factors, and Parameters for Individual Pathways

Eood Pathways

Storage Times for Contaminated Foodstuffs ......... 10

Storage Time Ingrowth and Decay Factors .......... 10

Storage Correction Factors

Drinking vater .................... 11

Irrigation water $\ldots \ldots \ldots \ldots \ldots \ldots \ldots \ldots \ldots \ldots \ldots$

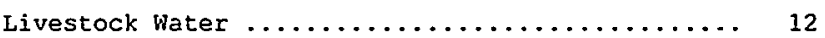

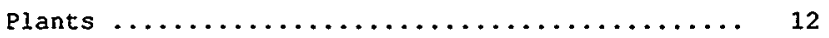

Livestock Fodder ................... 13

Meat and Milk .......................... 13

Fish and Crustacea $\ldots \ldots \ldots \ldots \ldots \ldots \ldots \ldots \ldots \ldots$

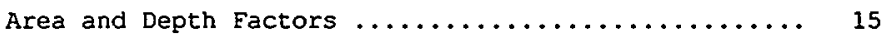

Dose Conversion and Environmental Transport Factors

Plant ............................ 17

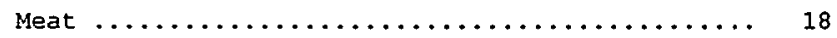

Milk ................................... 19

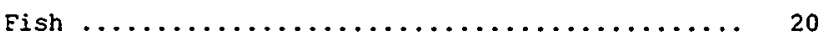

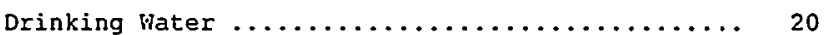

Dose/Source Ratios

Plant ........................... 21

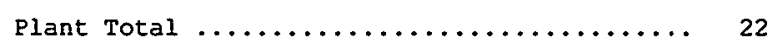

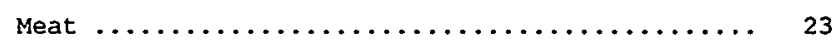

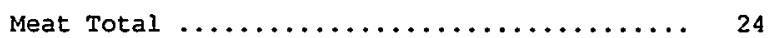

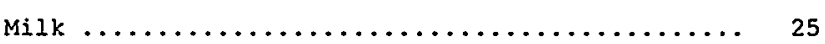

Milk Total ..................... 26

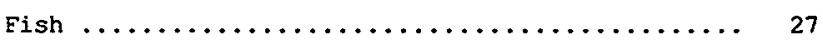

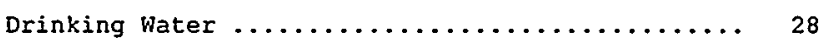

Concentration Ratios

Plant/Air and Plant/Water ................ 29

Plant/Soil ........................... 29

Meat/Fodder, Fodder/Air, Eodder/Water ........ 31

Fodder/Soil $\ldots \ldots \ldots \ldots \ldots \ldots \ldots \ldots \ldots \ldots \ldots \ldots \ldots \ldots \ldots$

Meat/Soil ......................... 33

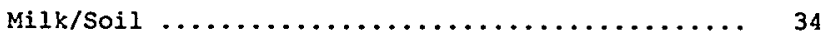

Soil Ingestion Pathway

Dose/Source Ratios..................... 35

Dose Conversion and Environmental Transport Factors . 35 


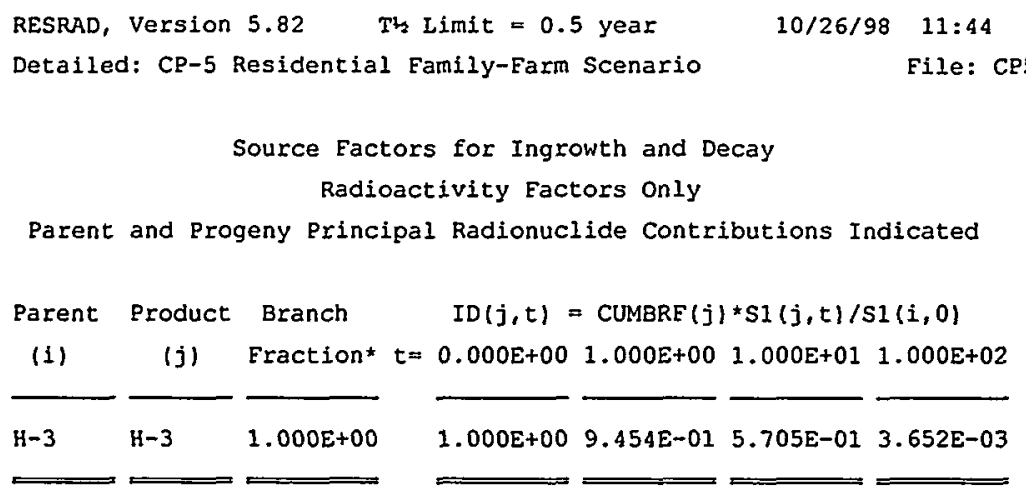

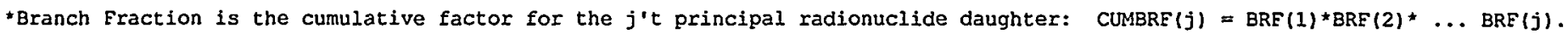

\footnotetext{
Source Factors for Ingrowth and Decay Combined Radioactivity and Leaching Factors
}

Parent and Progeny Principal Radionuclide Contributions Indicated

Parent Product Branch $\quad S E(j, t)=\operatorname{BRE}(i) * S 1(j, t) / S 1(i, 0)$

(i) (j) Eraction* $t=0.000 E+001.000 E+001.000 E+011.000 E+02$

$\longrightarrow$ H-3

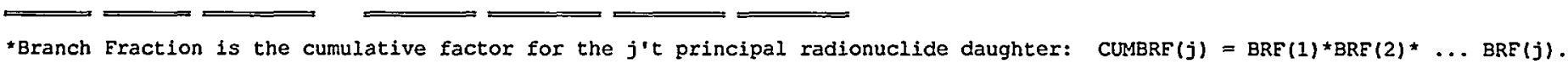
The effect of volatilization was also considered when computing the source factors for $\mathrm{H}-3$ and $\mathrm{C}-14$. 


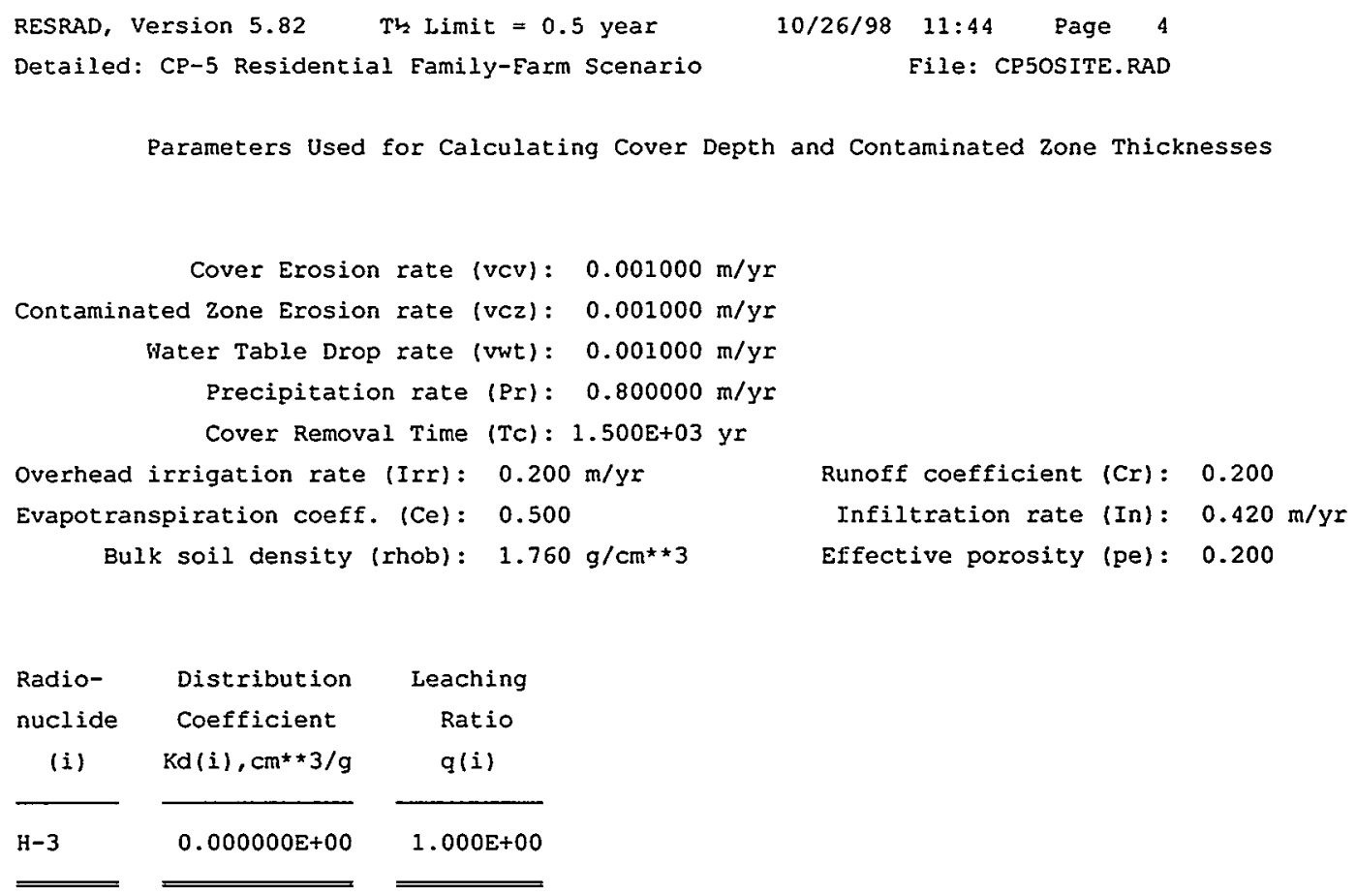


RESRAD, Version $5.82 \quad T$ Limit $=0.5$ year

Detailed: CP-5 Residential Family-Farm Scenario
10/26/98 11:44 Page 5

File: CPSOSITE.RAD

Occupancy, Cover/Depth, and Area Factors for Ground Pathway

$$
\begin{aligned}
\text { Occupancy Factor (FO1): } & 0.600 \\
\text { Area }(A): & 2430 . \text { sq. meters } \\
\text { Initial cover depth }(C d): & 1.500 \text { meters }
\end{aligned}
$$

Initial contaminated zone thickness $(T)$ : 15.240 meters

Time Dependence of Cover/Depth Factor [FCTR_COV_DEPTH $(i, t)$ ]

\begin{tabular}{|c|c|c|c|c|c|}
\hline Nuclide & & ECTR & $\operatorname{AREA}(i, t)$ & dimensionle & ss) \\
\hline (i) & $t=$ & $0.000 \mathrm{E}+00$ & $1.000 \mathrm{E}+00$ & $1.000 \mathrm{E}+01$ & $1.000 \mathrm{E}+02$ \\
\hline $\mathrm{H}-3$ & & $1.000 \mathrm{E}+00$ & $1.000 E+00$ & $1.000 \mathrm{E}+00$ & $1.000 \mathrm{E}+00$ \\
\hline
\end{tabular}

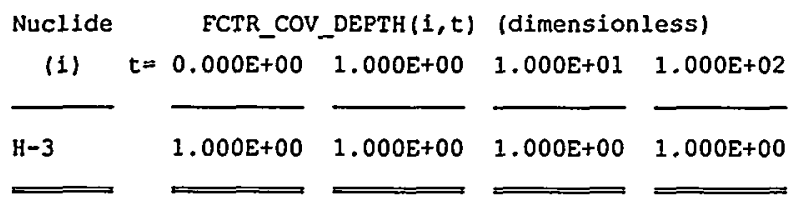

Time Dependence of Area Factor [FCTR_AREA $(i, t)$ ]

\begin{tabular}{|c|c|c|c|c|c|c|c|}
\hline Parent & Product & $\operatorname{DCE}(j, 1) *$ & & ETElj & $j, 1, t$ ) (din & mensionless & \\
\hline (1) & (j) & & $t=$ & $0.000 \mathrm{E}+00$ & $1.000 \mathrm{E}+00$ & $1.000 \mathrm{E}+01$ & $1.000 \mathrm{E}+02$ \\
\hline$H-3$ & $\mathrm{H}-3$ & $0.000 \Sigma+00$ & & $6.000 \mathrm{E}-01$ & $6.000 E-01$ & $6.000 \mathrm{E}-01$ & $6.000 \mathrm{E}-01$ \\
\hline
\end{tabular}

Dose Conversion and Environmental Transport Factors for the Ground Pathway ( $p=1)$

- The dose conversion factor units are (mrem/yr)/(pci/g) at infinite depth and area.

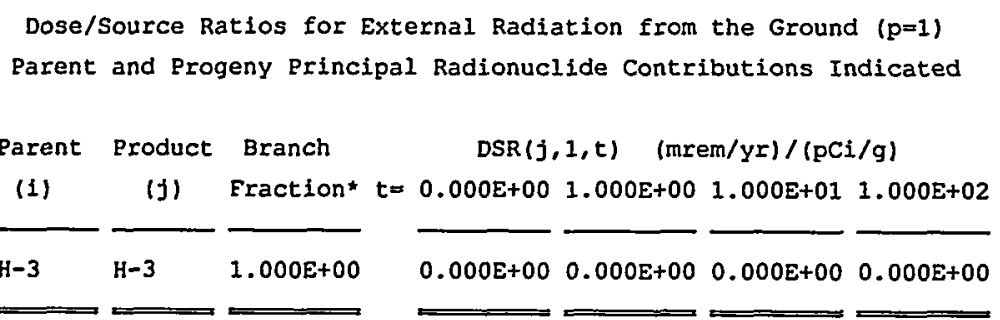

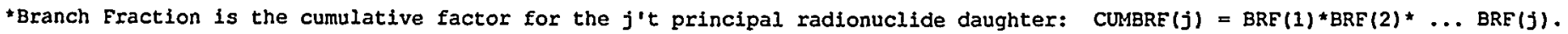
The DSR includes contributions from associated (half-life $\leq 0.5 \mathrm{yr}$ ) daughters. 


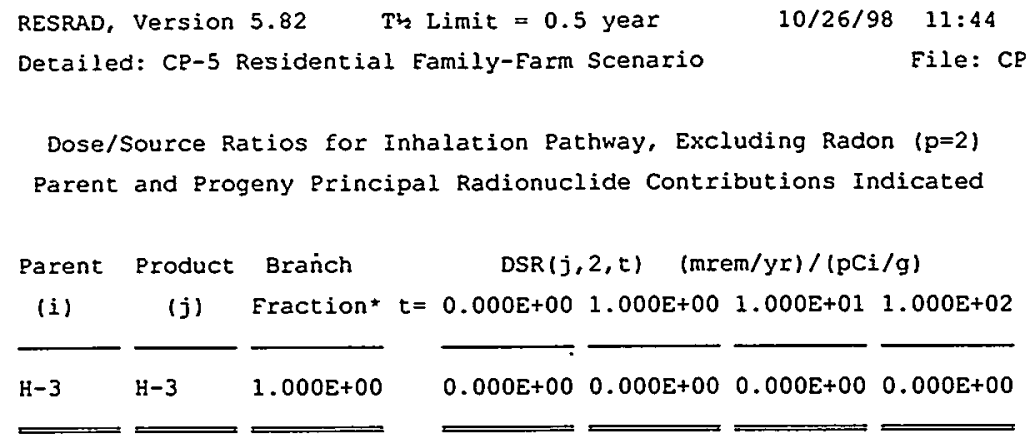

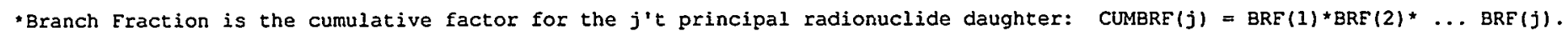
The DSR includes contributions from associated (half-life $\leq 0.5 \mathrm{yr}$ ) daughters.

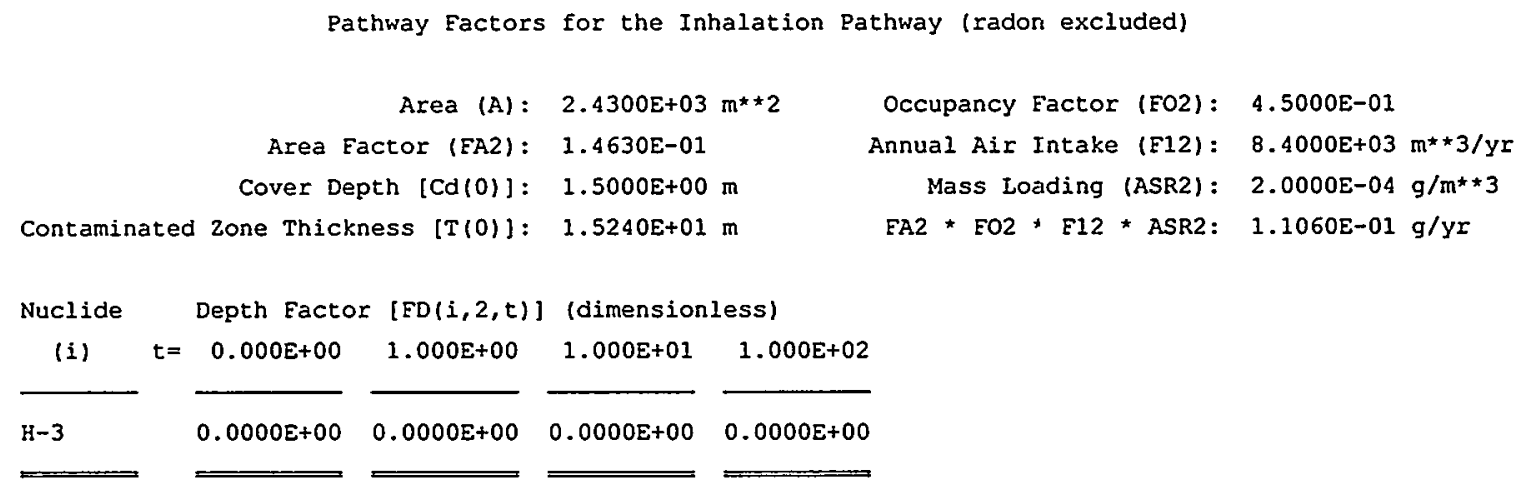




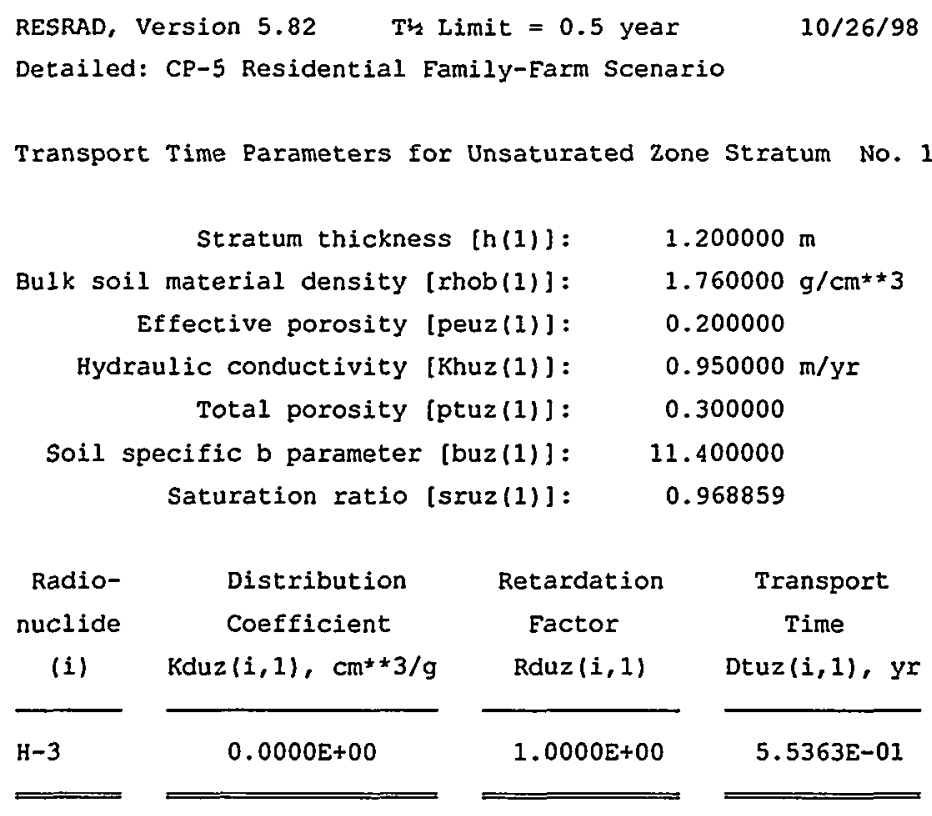

Transport Time Parameters for Unsaturated Zone Stratum No. 2

Stratum thickness $[\mathrm{h}(2)]$ : $18.000000 \mathrm{~m}$

Bulk soil material density [rhob(2)]:

$1.500000 \mathrm{~g} / \mathrm{cm}^{\star \star} 3$

Effective porosity [peuz(2)]:

0.200000

Hydraulic conductivity [Khuz(2)]:

$50.000000 \mathrm{~m} / \mathrm{yr}$

Total porosity [ptuz(2)] : 0.400000

Soil specific b parameter [buz(2)]: 7.750000

Saturation ratio [sruz(2)]: 0.772323

\begin{tabular}{|c|c|c|c|}
\hline $\begin{array}{l}\text { Radio- } \\
\text { nuclide } \\
\text { (i) }\end{array}$ & $\begin{array}{c}\text { Distribution } \\
\text { Coefficient } \\
\operatorname{Kduz}(i, 2), \mathrm{cm}^{\star \star} 3 / \mathrm{g}\end{array}$ & $\begin{array}{l}\text { Retardation } \\
\text { Factor } \\
\text { Rduz }(i, 2)\end{array}$ & $\begin{array}{c}\text { Transport } \\
\text { Time } \\
\text { Dtuz }(i, 2), y r\end{array}$ \\
\hline $\mathrm{H}-3$ & $0.0000 \mathrm{E}+00$ & $1.0000 \mathrm{E}+00$ & $6.6199 \mathrm{E}+00$ \\
\hline
\end{tabular}

Transport Time Parameters for Unsaturated Zone created by the Falling Water Table

Water table drop rate [vwt]: $0.001000 \mathrm{~m} / \mathrm{yr}$

Bulk soll material density [rhobaq]: $1.500000 \mathrm{~g} / \mathrm{cm}^{\star \star 3}$

Effective porosity [peaq] : 0.200000

Hydraulic conductivity [Khaq]: $950.000000 \mathrm{~m} / \mathrm{yr}$

Total porosity [ptaq] : 0.300000

Soil specific b parameter [bag]: 11.400000

Saturation ratio [sruag]: $\quad 0.741279$

\begin{tabular}{|c|c|c|c|}
\hline $\begin{array}{l}\text { Radio- } \\
\text { nuclide } \\
\text { (1) }\end{array}$ & $\begin{array}{l}\text { Distribution } \\
\text { Coefficient } \\
\text { Kdaq(i), } \mathrm{Cm} * \star 3 / \mathrm{g}\end{array}$ & $\begin{array}{l}\text { Retardation } \\
\text { Factor } \\
\text { Rduag(i) }\end{array}$ & $\begin{array}{c}\text { Minimum } \\
\text { Transport } \\
\text { Time } \\
\text { Dtuaq(i), yr }\end{array}$ \\
\hline $\mathrm{H}-3$ & $0.0000 E+00$ & $1.0000 \mathrm{E}+00$ & $2.5331 E-03$ \\
\hline
\end{tabular}


RESRAD, Version 5.82 Th Limit $=0.5$ year

Detailed: CP-5 Residential Family-Farm Scenario
10/26/98 11:44 Page 8

Eile: CP5OSITE.RAD

Dilution Factor and Rise Time Parameters for Nondispersion (ND) Model

Aquifer contamination depth at well $(z): 1.63579 \mathrm{E}+00 \mathrm{~m}$

Depth of water intake below water table $(\mathrm{dw}): 5.00000 \mathrm{E}+00 \mathrm{~m}$

Infiltration rate (In): $4.20000 \mathrm{E}-01 \mathrm{~m} / \mathrm{yr}$

Aquifer water flow rate (Vwfr): $1.90000 \mathrm{E}+01 \mathrm{~m} / \mathrm{yr}$

Hydraulic gradient $(J): 2.00000 \mathrm{E}-02$

Hydraulic conductivity of aquifer (Kszh): $9.50000 \mathrm{E}+02 \mathrm{~m} / \mathrm{yr}$

Contaminated zone extent parallel to gradient (1): $7.40000 \mathrm{E}+01 \mathrm{~m}$

Distance below contaminated zone to water table (h): $0.19200 \mathrm{E}+02 \mathrm{~m}$

Initial thickness of uncontaminated cover (Cd): $0.15000 \mathrm{E}+01 \mathrm{~m}$

Initial thickness of contaminated zone $(T): 0.15240 \mathrm{E}+02 \mathrm{~m}$

Effective porosity of saturated zone (pesz): $0.20000 \mathrm{E}+00$

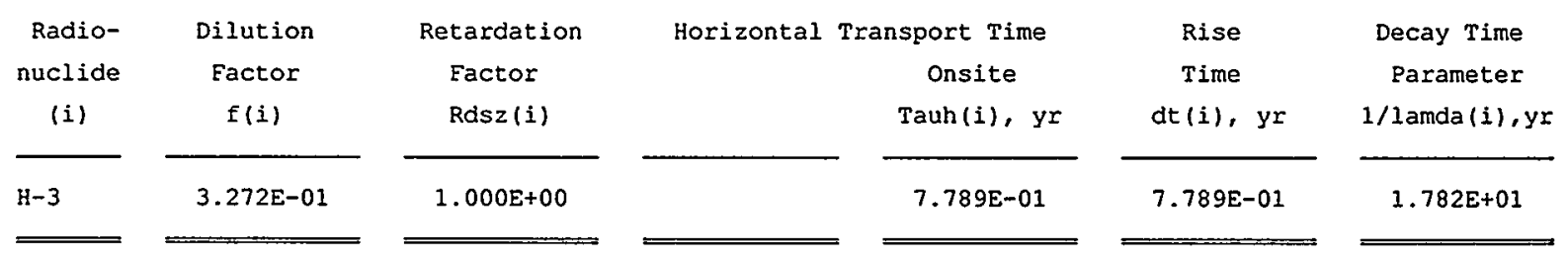

Primary Parameters Used for Calculating Water/Soil

Concentration Ratios for Groundwater Pathway Segment

Model used: Nondispersion (ND)

Bulk soil density in contaminated zone (rhob): $1.760 \mathrm{~g} / \mathrm{cm}^{\star \star} 3$

\begin{tabular}{|c|c|c|c|c|c|}
\hline Radio- & Dilution & Retardation & Breakt & bugh Time & Rise \\
\hline nuclide & Factor & Factor & Chain & Single Nuclide & Time \\
\hline (i) & $f(i)$ & $\operatorname{Rdcz}(i)$ & year & $D t(i), y x$ & $\operatorname{dt}(i), y r$ \\
\hline $\mathrm{H}-3$ & $3.272 \mathrm{E}-01$ & $1.000 \mathrm{E}+00$ & $7.176 \mathrm{E}+00$ & $7.176 \mathrm{E}+00$ & $7.789 \mathrm{E}-01$ \\
\hline
\end{tabular}




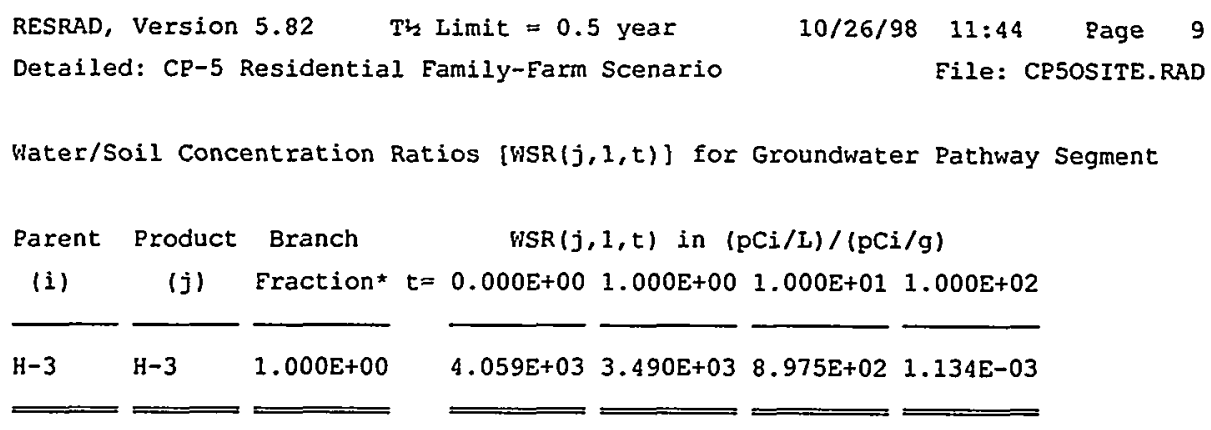

Water/Soil Concentration Ratios $\operatorname{LGR}(j, 2, t)]$ for Surface Water Pathway Segment

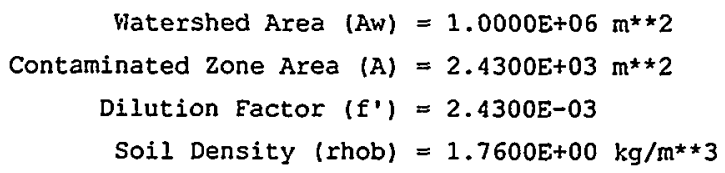


RESRAD, Version $5.82 \quad$ Th Limit $=0.5$ year

Detailed: CP-5 Residential Family-Farm Scenario
10/26/98 11:44 Page 10

File: CPSOSITE.RAD

Storage Times For Contaminated Foodstuffs

\begin{tabular}{l|rr}
$k \mid$ Food Item & STOR_T(k), days \\
\hline $1 \mid$ non-leafy plants & 14 \\
$2 \mid$ leafy plants & 1 & 1 \\
$3 \mid$ milk & $\mid$ & 20 \\
$4 \mid$ meat & 1 & 7 \\
5 | fish & 1 \\
6 | crustacea & 1 \\
7 | well water & 45 \\
8 | surface water & | \\
9 | livestock fodder & |
\end{tabular}

Storage Time Ingrowth and Decay Factors

Storage Time for $k^{\prime}$ th Foodstuff: $t=$ STOR_T $(k)$, days

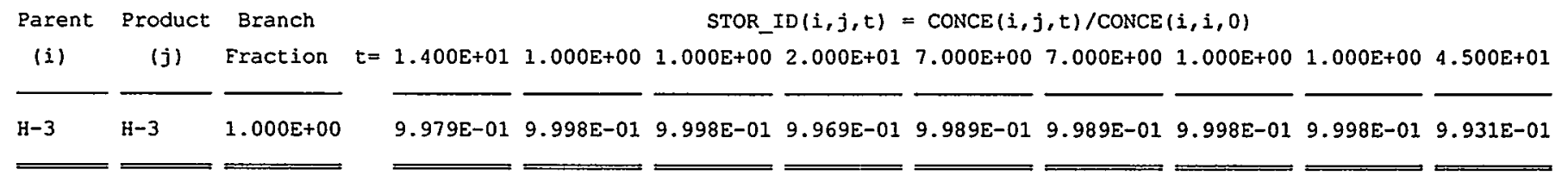

$\operatorname{CONCE}(i, j, t) / \operatorname{CONCE}(i, i, 0)$ is the concentration ratio of Product $(j)$ at time to Parent(i) at start of storage time. 
RESRAD, Version $5.82 \quad T$ Limit $=0.5$ year

Detalled: CP-5 Residential Family-Farm Scenario
10/26/98 11:44 Page 11

File: CP5OSITE.RAD

Storage Time Correction Factors

Drinking Water from Hell and/or Surface

Harvest Time $=t-2.74 E-03 \mathrm{yr}$; Consumption $\mathrm{Time}=t \mathrm{yr}$

\begin{tabular}{|c|c|c|c|c|c|c|c|}
\hline Parent & Product & Branch & & & CEWW $(j$, & $, t, 1) \#$ & \\
\hline (i) & (j) & Fraction & $t=$ & $0.000 E+00$ & $1.000 E+00$ & $1.000 E \div 01$ & $1.000 \mathrm{E}+02$ \\
\hline $\mathrm{H}-3$ & $\mathrm{H}-3$ & 1. $000 \mathrm{E}+00$ & & $1.000 E+00$ & $9.998 E-01$ & $9.998 E-01$ & $9.998 \mathrm{E}-01$ \\
\hline
\end{tabular}

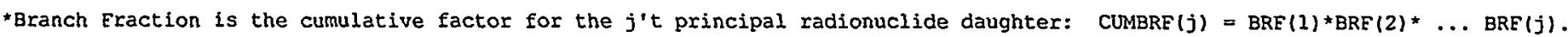
\#Correction factor $=$ (concentration in media at consumption time)/(concentration at harvest time) .

Storage Time Correction Factors

Irrigation Water for Nonleafy Plants from Well and/or Surface Harvest Time $=t-4.11 \mathrm{E}-02 \mathrm{yr}$; Consumption $\mathrm{Time}=t-3.83 \mathrm{E}-02 \mathrm{yr}$

\begin{tabular}{|c|c|c|c|c|c|c|c|}
\hline Parent & Product & Branch & & & CEWW $(j$ & $t, 2) \#$ & \\
\hline (i) & (j) & Fraction* & $t=$ & $0.000 E+00$ & $1.000 \mathrm{E}+00$ & $1.000 \mathrm{E}+01$ & $1.000 \mathrm{E}+02$ \\
\hline $\mathrm{H}-3$ & $\mathrm{H}-3$ & $1.000 \mathrm{E}+00$ & & $1.000 E+00$ & $9.998 \mathrm{E}-01$ & $9.998 \mathrm{E}-01$ & $9.998 E-01$ \\
\hline
\end{tabular}

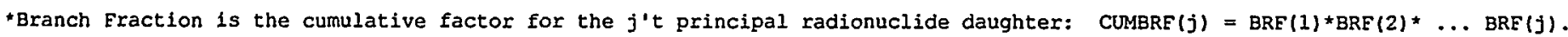
HCorrection factor $=$ (concentration in media at consumption time)/(concentration at harvest time) .

Storage Time Correction Factors

Irrigation Water for Leafy Plants from Well and/or Surface Harvest Time $=\mathrm{t}-5.48 \mathrm{E}-03 \mathrm{yr}$; Consumption Time $=\mathrm{t}-2.74 \mathrm{E}-03 \mathrm{yr}$

Parent Product Branch CEWW $(j, t, 3) \#$

(1) (j) Fraction* $t=0.000 E+00 \quad 1.000 E+001.000 E+01 \quad 1.000 E+02$

$\longrightarrow$ H-3

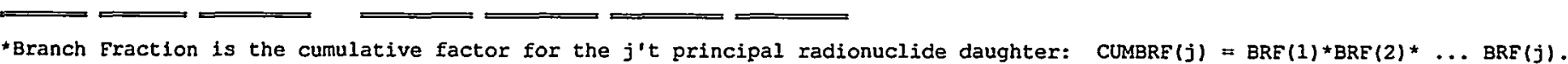
HCorrection factor $=$ (concentration in media at consumption time)/(concentration at harvest time).

Storage Time Correction Factors

Irrigation Water for Livestock (Milk) Fodder from Well and/or Surface Harvest $\mathrm{T}$ ime $=t-1.29 \mathrm{E}-01 \mathrm{yr}$; Consumption $\mathrm{Time}=t-1.26 \mathrm{E}-01 \mathrm{yr}$

Parent Product Branch CEWW $(j, t, 5)$ \#

(i) (j) Eraction* $t=0.000 E+00 \quad 1.000 E+001.000 E+01 \quad 1.000 E+02$

H-3

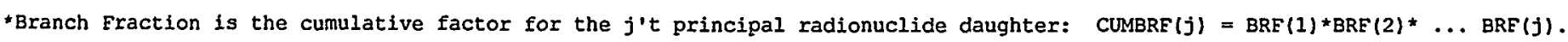
$\sharp$ Correction factor $=$ (concentration in media at consumption time)/(concentration at harvest time) . 
RESRAD, Version $5.82 \quad T$ Th Limit $=0.5$ year

Detailed: CP-5 Residential Family-Farm Scenario
10/26/98 $11: 44 \quad$ Page 12

File: CPSOSITE.RAD

Storage Time Correction Factors

Irrigation Water for Iivestock (Meat) Fodder from Well and/or Surface

Harvest $\mathrm{Time}=t-1.81 \mathrm{E}-01 \mathrm{yr}$; Consumption Time $=t-1.78 \mathrm{E}-01 \mathrm{yr}$

Parent Product Branch CEWW $(j, t, 7) \#$

(i) (j) Fraction* $t=0.000 \mathrm{E}+001.000 \mathrm{E}+001.000 \mathrm{E}+011.000 \mathrm{E}+02$

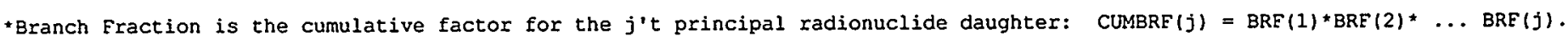
\#Correction factor $=$ (concentration in media at consumption time)/(concentration at harvest time).

Storage Time Correction Factors

Livestock (Milk) Water from Well and/or Surface

Harvest Time $=t-5.48 \mathrm{E}-03 \mathrm{yr}$; Consumption $\mathrm{Time}=t-2.74 \mathrm{E}-03 \mathrm{yr}$

Parent Product Branch CEWH $(j, t, 4)$ \#

(i) (j) Fraction* $t=0.000 E+00 \quad 1.000 E+00 \quad 1.000 E+01 \quad 1.000 E+02$

\begin{tabular}{|c|c|c|c|c|c|}
\hline $\mathrm{H}-3$ & $\mathrm{H}-3$ & $1.000 \mathrm{E}+00$ & $1.000 E+00$ & $9.998 \mathrm{E}-01$ & $9.998 \mathrm{E}-01 \quad 9.998 \mathrm{E}-01$ \\
\hline
\end{tabular}

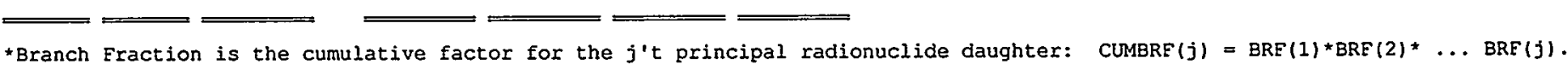
\#Correction factor $=$ (concentration in media at consumption time)/(concentration at harvest time) .

Storage Time Correction Factors

Livestock (Meat) Hater from Well and/or Surface

Harvest $\mathrm{Time}=t-5.75 \mathrm{E}-02 \mathrm{yr}$; Consumption Time $=t-5.48 \mathrm{E}-02 \mathrm{yr}$

Parent Product Branch CFW $(j, t, 6) \#$

(i) (j) Eraction* $t=0.000 E+001.000 E+001.000 E+011.000 E+02$

\begin{tabular}{|c|c|c|c|c|c|c|}
\hline $\mathrm{H}-3$ & $\mathrm{~K}-3$ & $1.000 E+00$ & $1.000 \mathrm{E}+00$ & $9.998 \mathrm{E}-01$ & $9.998 E-01$ & $9.998 \mathrm{E}-01$ \\
\hline
\end{tabular}

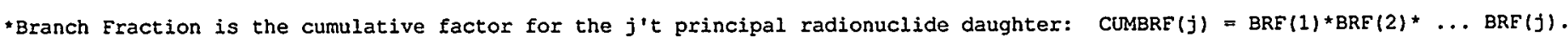
\#Correction factor $=$ (concentration in media at consumption time)/(concentration at harvest time) .

Storage Time Correction Factors for Nonleafy Plants

Harvest Time $=t-3.83 \mathrm{E}-02 \mathrm{yr}$; Consumption $\mathrm{Time}=t \mathrm{yr}$

\begin{tabular}{|c|c|c|c|c|c|c|c|}
\hline Parent & Product & Branch & & & $\operatorname{CF} 3(j$, & $1, t) \#$ & \\
\hline (i) & (j) & Eraction* & $t=$ & $0.000 E+00$ & $1.000 \mathrm{E}+00$ & $1.000 \mathrm{E}+01$ & $1.000 \mathrm{E}+02$ \\
\hline $\mathrm{H}-3$ & $\mathrm{H}-3$ & I. $000 \mathrm{E}+00$ & & $1.000 \mathrm{E}+00$ & $9.979 \mathrm{E}-01$ & $9.979 \mathrm{E}-01$ & $9.979 \mathrm{E}-01$ \\
\hline
\end{tabular}

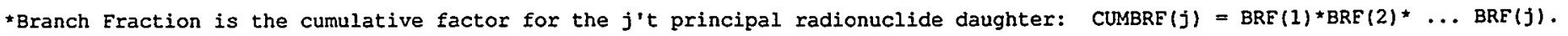
\#Correction factor = (concentration in media at consumption time)/(concentration at harvest time). 
RESRAD, Version $5.82 \quad T$ Th limit $=0.5$ year

Detailed: CP-5 Residential Family-Farm Scenario
$10 / 26 / 98 \quad 11: 44 \quad$ Page 13

File: CP5OSITE.RAD

Storage Time Correction Factors for Leafy Plants

Harvest Time $=t-2.74 \mathrm{E}-03 \mathrm{yr}$; Consumption $\mathrm{Time}=\mathrm{t} \mathrm{yr}$

\begin{tabular}{|c|c|c|c|c|c|c|c|}
\hline Parent & Product & Branch & & & $\operatorname{CE} 31 j, 2$ & $2, t) \#$ & \\
\hline (i) & $(j)$ & Fraction* & $t=$ & $0.000 \mathrm{E}+00$ & $1.000 \mathrm{E}+00$ & $1.000 \mathrm{E}+01$ & $1.000 \mathrm{E}+02$ \\
\hline $\mathrm{H}-3$ & $\mathrm{H}-3$ & $1.000 E+00$ & & 1. $000 \mathrm{E}+00$ & $9.998 \mathrm{E}-01$ & $9.998 E-01$ & $9.998 \mathrm{E}-01$ \\
\hline
\end{tabular}

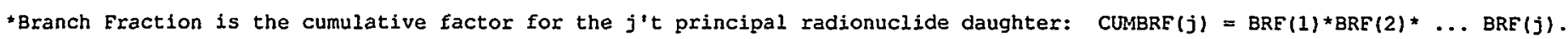
\#Correction factor $=$ (concentration in media at consumption time)/(concentration at harvest time) .

Storage Time Correction Factors for Iivestock (Meat) Fodder Harvest Time $=t-1.78 \mathrm{E}-01 \mathrm{yr}$; Consumption Time $=t-5.48 \mathrm{E}-02 \mathrm{yr}$

\begin{tabular}{|c|c|c|c|c|c|c|c|}
\hline Parent & Product & Branch & & & CFLE $(j$ & $(1, t) \#$ & \\
\hline (1) & (j) & Eraction* & $t=$ & $0.000 E+00$ & $1.000 E+00$ & $1.000 E+01$ & $1.000 \mathrm{E}+02$ \\
\hline $\mathrm{H}-3$ & $\mathrm{H}-3$ & $1.000 E+00$ & & 1. $000 \mathrm{E}+00$ & $9.931 \mathrm{E}-01$ & $9.931 E-01$ & $9.931 \mathrm{E}-01$ \\
\hline
\end{tabular}

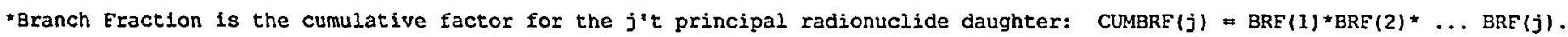
\#Correction factor $=$ (concentration in media at consumption time)/(concentration at harvest time).

Storage Time Correction Factors for Livestock (Milk) Fodder Harvest $\mathrm{T}$ ime $=\mathrm{t}-1.26 \mathrm{E}-01 \mathrm{yr}$; Consumption Time $=t-2.74 \mathrm{E}-03 \mathrm{yr}$

Parent Product Branch $\operatorname{CELF}(j, 2, t) \#$

(1) (j) Fraction $t=0.000 E+001.000 E+001.000 E+01 \quad 1.000 E+02$

\begin{tabular}{|c|c|c|c|c|c|c|}
\hline $\mathrm{H}-3$ & $\mathrm{H}-3$ & $1.000 \mathrm{E}+00$ & $1.000 \mathrm{E}+00$ & $9.931 \mathrm{E}-01$ & $9.931 \mathrm{E}-01$ & $9.931 E-01$ \\
\hline
\end{tabular}

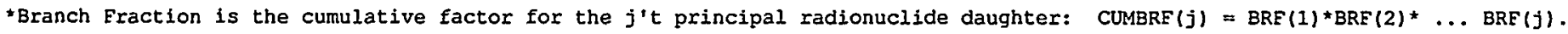
\#Correction factor $=$ (concentration in media at consumption time)/(concentration at harvest time).

Storage Time Correction Factors for Meat

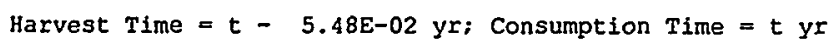

\begin{tabular}{|c|c|c|c|c|c|c|c|}
\hline Parent & Product & & & & $C E 45$ (j) & $(1, t) \#$ & \\
\hline (i) & (j) & Fraction * & $t=$ & $0.000 \mathrm{E}+00$ & $1.000 \mathrm{E}+00$ & $1.000 \mathrm{E}+01$ & 1. $000 \mathrm{E}+02$ \\
\hline$H-3$ & $\mathrm{H}-3$ & $1.000 \mathrm{E}+00$ & & $1.000 E+00$ & $9.969 \mathrm{E}-01$ & $9.969 \mathrm{E}-01$ & $9.969 \mathrm{E}-01$ \\
\hline
\end{tabular}

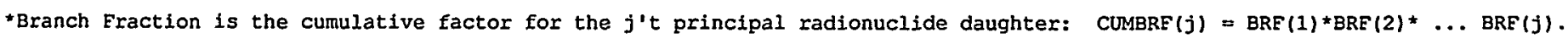
\#Correction factor $=$ (concentration in media at consumption time)/(concentration at harvest time) . 


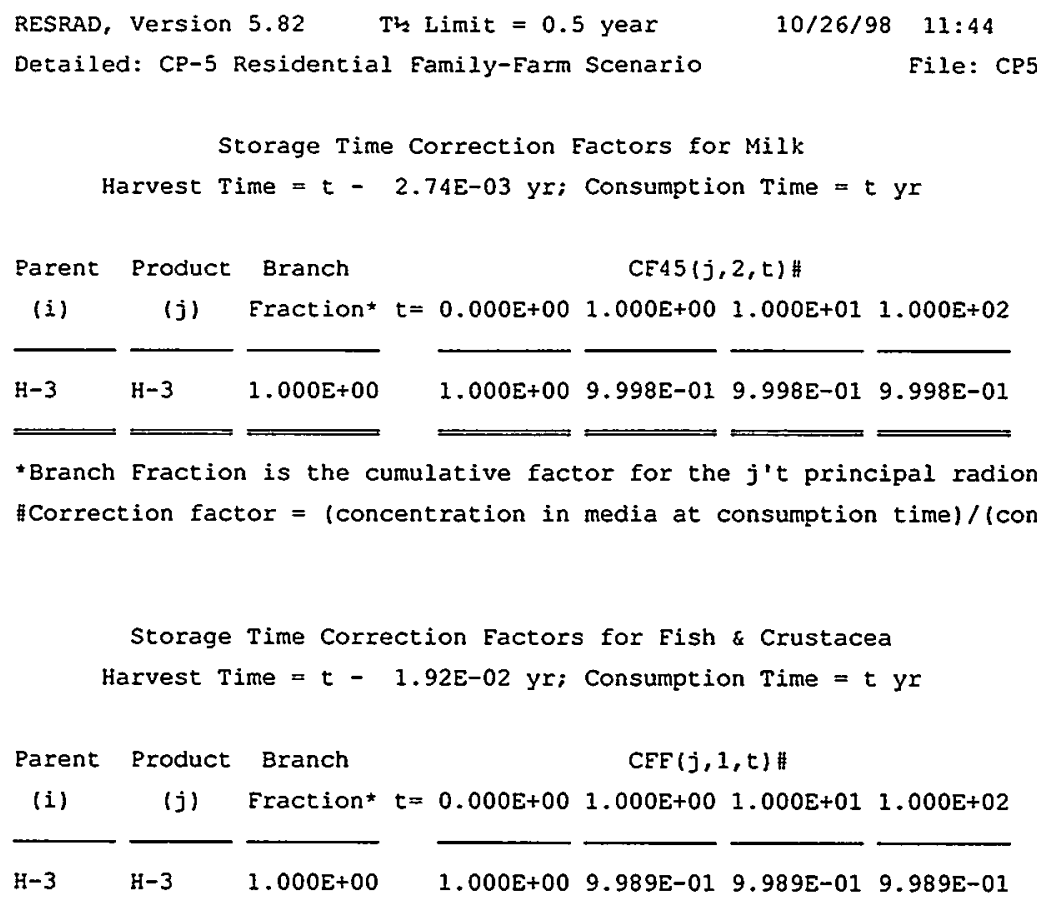




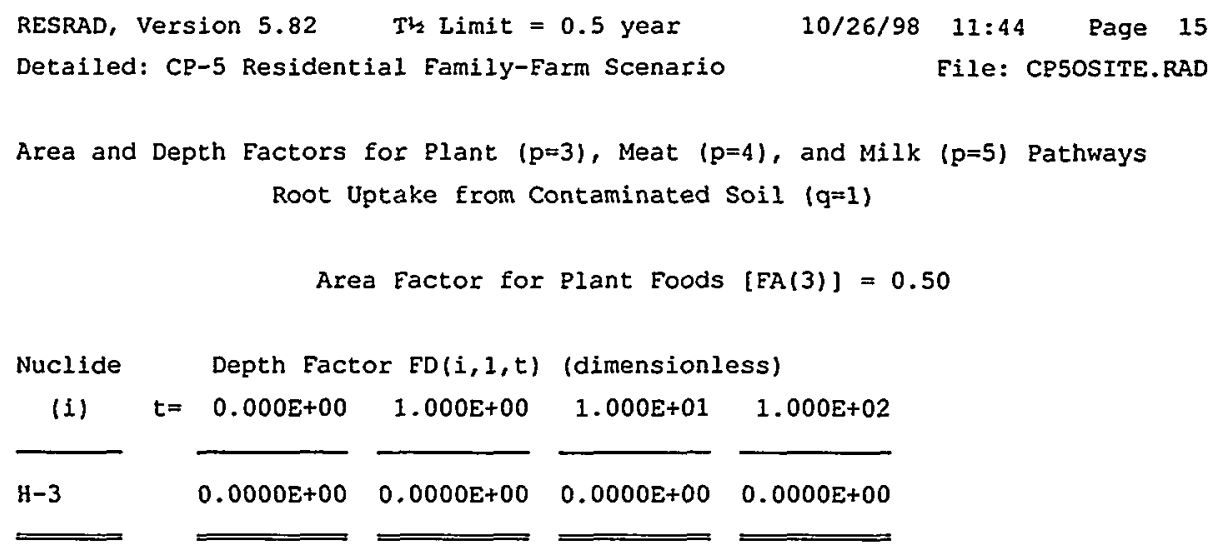


RESRAD, Version $5.82 \quad T$ Th Limit $=0.5$ year $\quad 10 / 26 / 98 \quad 11: 44 \quad$ Page 16

Detailed: CP-5 Residential Eamily-Farm Scenario File: CP5OSITE.RAD

Area and Depth Factors for Plant $(p=3)$, Meat $(p=4)$, and Milk $(p=5)$ Pathways Overhead Irrigation ( $q=4)$

Area Factor for Plant Eoods $[E A(3)]=0.50$

The Depth Factor Value

$F D(i, p, q, t)=1.0000 E+00$

is applicable for all radionuclides(i) and times(t).

Area and Depth Factors for Meat $(p=4)$ and Milk $(p=5)$ Pathways

Transfer from Livestock Water $(q=5)$ and Soil $(q=6)$ Intake

Area Factor for Meat and Milk $[E A(p), p=4,5]=0.12$

The livestock water subpathway $(q=5)$ and livestock soil intake subpathway (q=6) occur only for the meat $(p=4)$ and milk $(p=5)$ pathways.

Area and Depth Factors for Meat $(p=4)$ and Milk (p=5) Pathways

Transfer from Livestock Water $(q=5)$ and Soil $(q=6)$ Intake

Area Factor for Meat and Milk $[E A(p), p=4,5]=0.12$

The livestock water subpathway $(q=5)$ and livestock soil intake subpathway ( $q=6)$ occur only for the meat $(p=4)$ and milk $(p=5)$ pathways. 


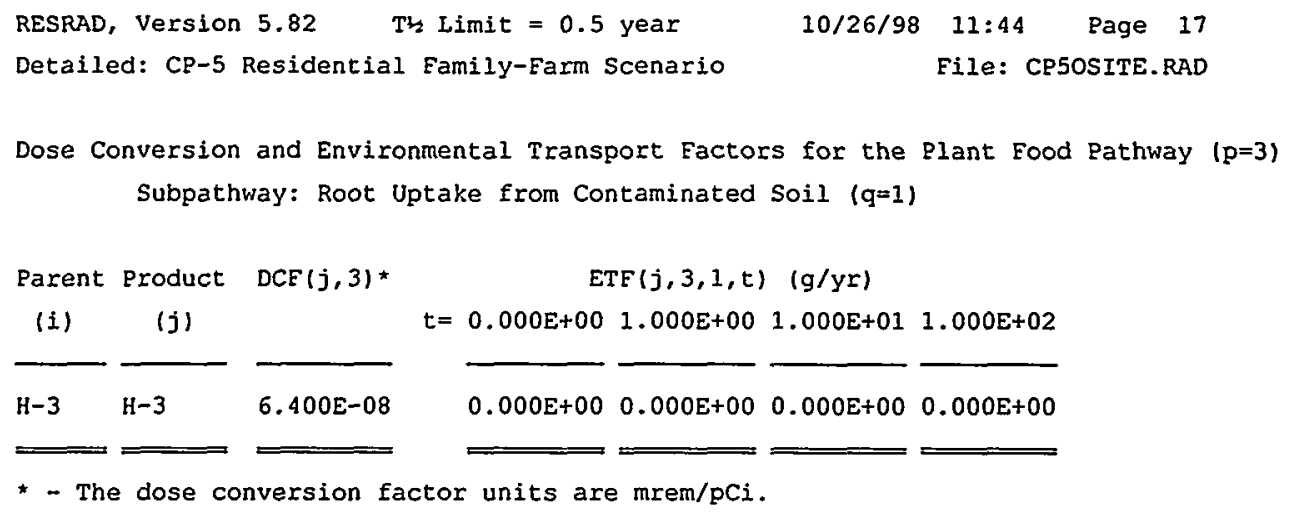


RESRAD, Version $5.82 \quad T$ th Limit $=0.5$ year

Detailed: CP-5 Residential Family-Farm Scenario
10/26/98 $11: 44 \quad$ Page 18

File: CPSOSITE.RAD

Dose Conversion and Environmental Transport Factors for the Meat Pathway $(p=4)$ Subpathway: Fodder Root Uptake from Contaminated Soil ( $q=1$ )

Parent Product DCF $(j, 4)$ *

$\operatorname{ETE}(j, 4,1, t)(g / y r)$

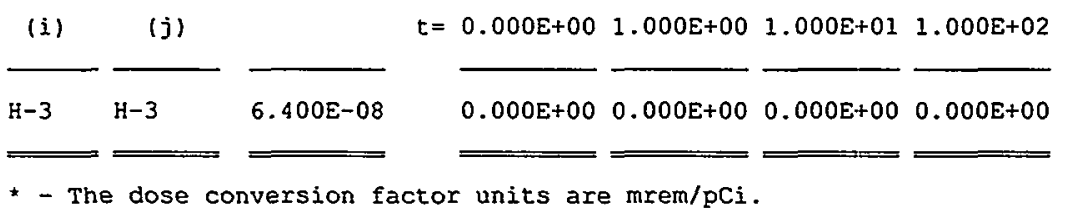

Dose Conversion and Environmental Transport Eactors for the Meat Pathway $(p=4)$ Subpathway: Fodder Foliar Uptake from Contaminated Dust $(q=2)$

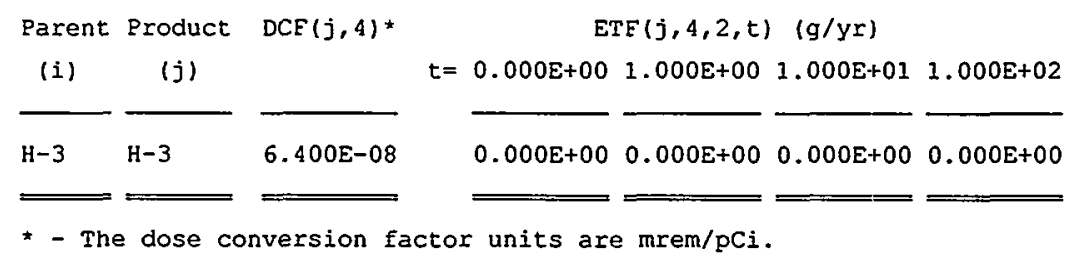

Dose Conversion and Environmental Transport Eactors for the Meat Pathway (p=4) Subpathway: Ditch Irrigation $(q=3)$

Parent Product $\operatorname{DCE}(j, 4)^{*}$

$\operatorname{ETF}(j, 4,3, t) * \operatorname{SE}(j, t)(g / y r)$

(i) (j) $\mathrm{t}=0.000 \mathrm{E}+00 \quad 1.000 \mathrm{E}+00 \quad 1.000 \mathrm{E} \div 01 \quad 1.000 \mathrm{E}+02$

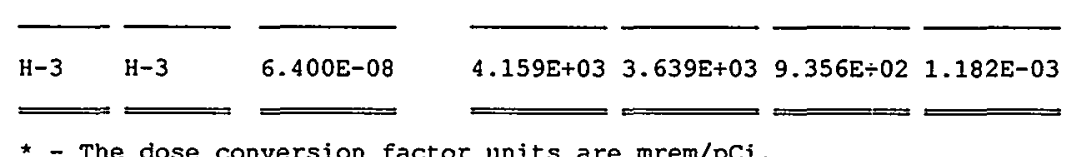

* - The dose conversion factor units are mrem/pci.

Dose Conversion and Environmental Transport Factors for the Meat Pathway $(p=4)$ Subpathway: Overhead Irrigation ( $q=4$ )

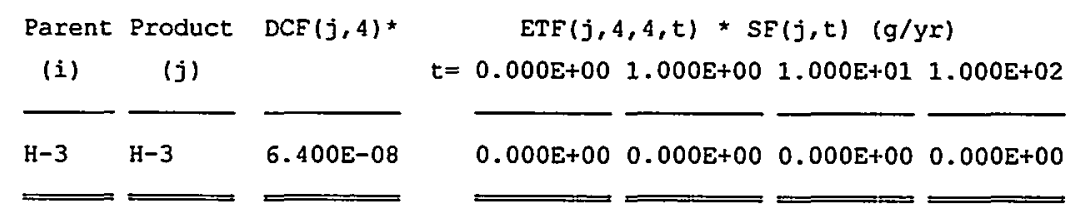

* - The dose conversion factor units are mrem/pci.

Dose Conversion and Environmental Transport Eactors for the Meat Pathway $(p=4)$ Subpathway: Livestock water $(q=5)$

Parent Product $\operatorname{DCF}(j, 4) * \quad \operatorname{ETF}(j, 4,5, t) * \operatorname{SF}(j, t)(g / y r)$

(i) (j) $\quad t=0.000 E+001.000 E+001.000 E+01 \quad 1.000 E+02$

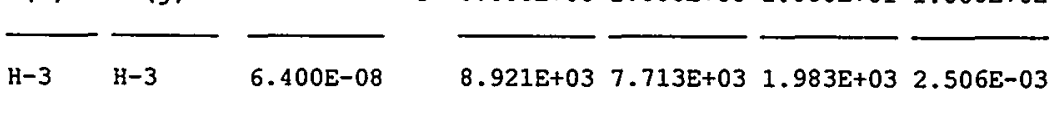

$=\Longrightarrow=$

* - The dose conversion factor units are mrem/pci. 


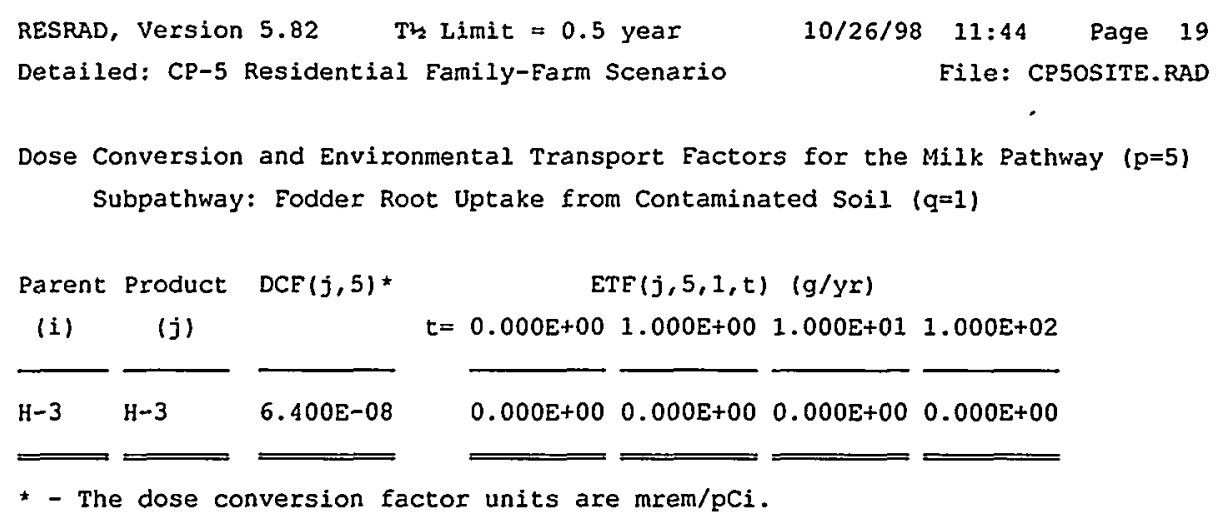

* - The dose conversion factor units are mrem/pCi. 


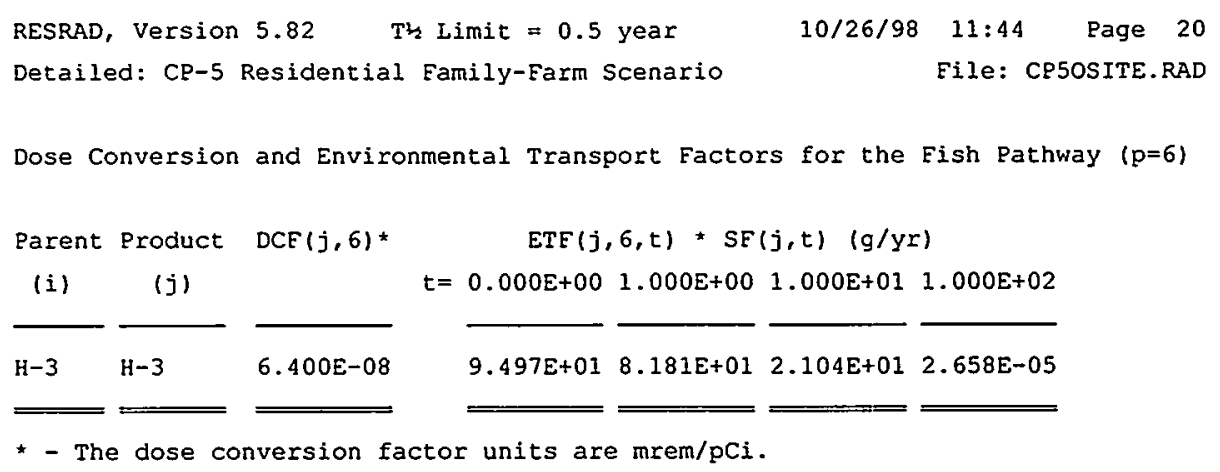


RESRAD, Version 5.82 Th Limit $=0.5$ year

Detalled: CP-5 Residential Family-Farm Scenario
$10 / 26 / 98 \quad 11: 44 \quad$ Page 21

File: CP5OSITE.RAD

Dose/Source Ratios for Internal Radiation from Ingestion of plant Foods $(p=3$ ) Subpathway: Root Uptake from Contaminated Soil ( $q=1$ )

Parent and Progeny Erincipal Radionuclide Contributions Indicated

Parent Product Branch $\operatorname{DSR}(j, 3,1, t)$ (mrem/yr)/(pCi/g)

(i) (j) Eraction* $t=0.000 E+00 \quad 1.000 E+001.000 E+01 \quad 1.000 E+02$

$\longrightarrow$ H-3

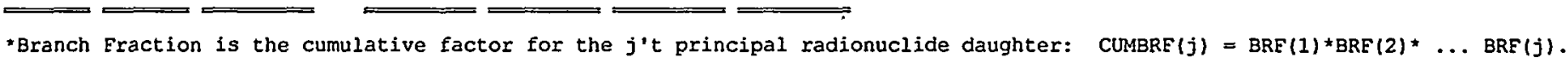
The DSR includes contributions from associated (half-life $\leq 0.5 \mathrm{yr}$ ) daughters.

Dose/Source Ratios for Internal Radiation from Ingestion of Plant Foods (p=3)

Subpathway: Eoliar Uptake from Contaminated Dust ( $q=2$ )

Parent and Progeny Principal Radionuclide Contributions Indicated

Parent Product Branch $\quad \operatorname{DSR}(j, 3,2, \mathrm{t}) \quad(\mathrm{mrem} / \mathrm{yr}) /(\mathrm{pCi} / \mathrm{g})$

(i) (j) Fraction* $t=0.000 E+001.000 E+001.000 E+01 \quad 1.000 E+02$

$\longrightarrow$ H-3

$\Longrightarrow=$

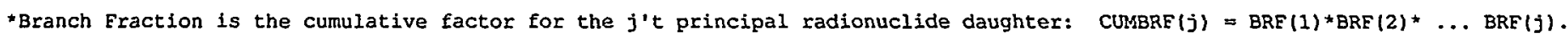
The DSR includes contributions from associated (half-life $\leq 0.5 \mathrm{yr}$ ) daughters.

Dose/Source Ratios for Internal Radiation from Ingestion of Plant Foods ( $p=3$ )

Subpathway: Ditch Irrigation ( $q=3$ )

Parent and Progeny Principal Radionuclide Contributions Indicated

Parent Product Branch $\operatorname{DSR}(j, 3,3, \mathrm{t}) \quad(\mathrm{mrem} / \mathrm{yr}) /(\mathrm{pCi} / \mathrm{g})$

(i) (j) Fraction* $t=0.000 E+00 \quad 1.000 E+001.000 E+01 \quad 1.000 E+02$

$\longrightarrow$ H-3

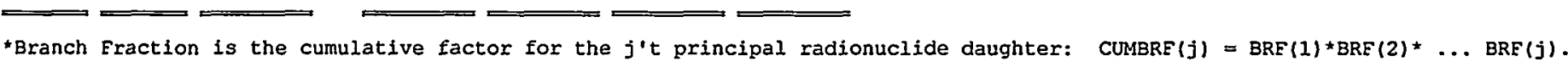
The DSR includes contributions from associated (half-life $\leq 0.5 \mathrm{yr}$ ) daughters.

Dose/Source Ratios for Internal Radiation from Ingestion of Plant Foods (p=3) Subpathway: overhead Irrigation $(q=4)$

Parent and Progeny Principal Radionuclide Contributions Indicated

Parent Product Branch $\operatorname{DSR}(j, 3,4, \mathrm{t})$ (mrem/yr)/(pCi/g)

(i) (j) Fraction $t=0.000 \mathrm{E}+001.000 \mathrm{E}+001.000 \mathrm{E}+01 \quad 1.000 \mathrm{E}+02$

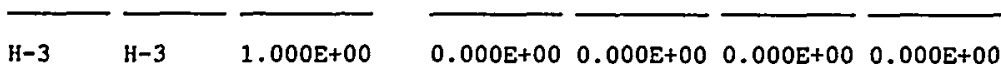

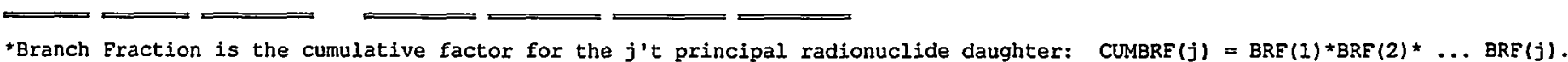
The DSR includes contributions from associated (half-life $\leq 0.5$ yr) daughters. 


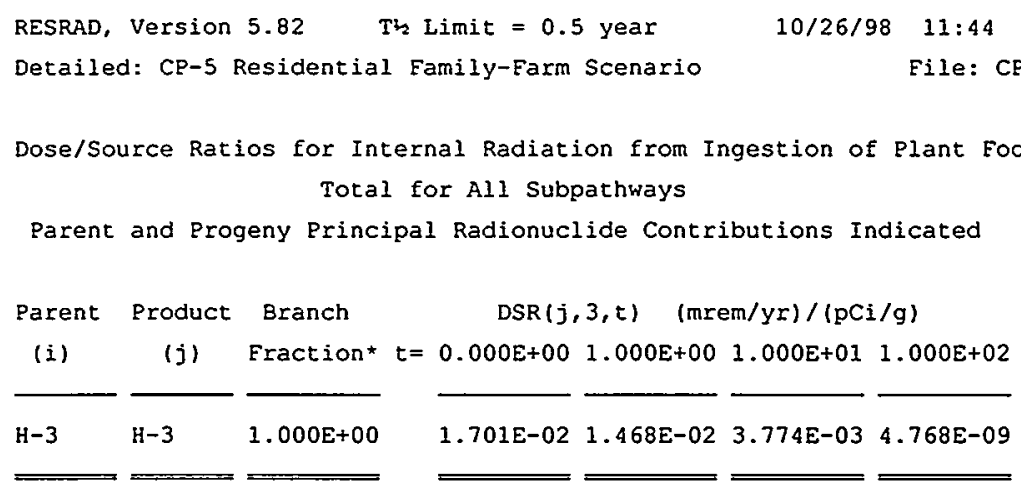

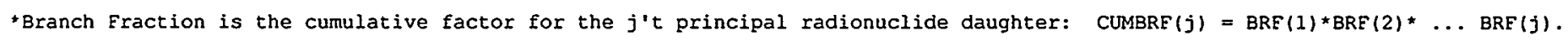
The DSR includes contributions from associated (half-life $\leq 0.5 \mathrm{yr}$ ) daughters. 


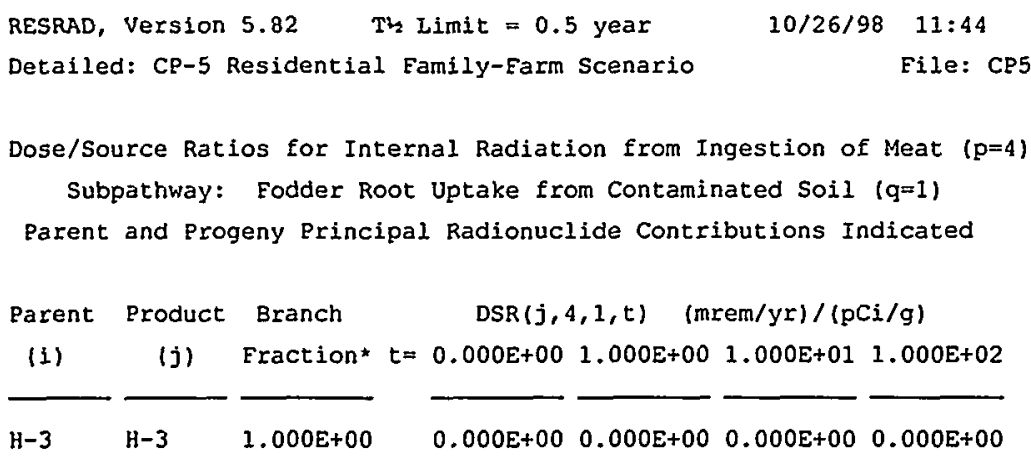

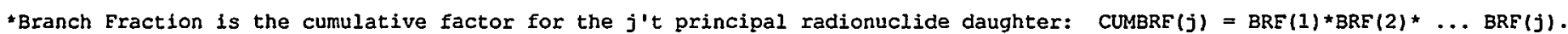
The DSR includes contributions from associated (half-life $\leq 0.5 \mathrm{yr}$ ) daughters.

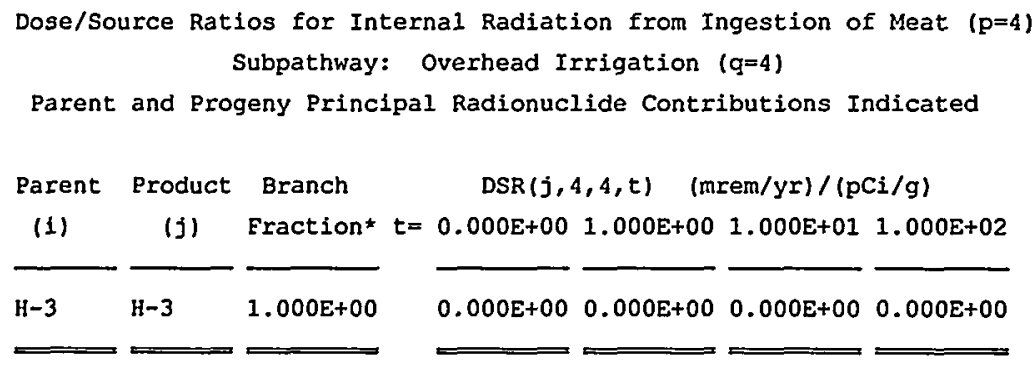

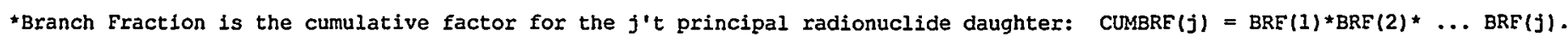
The DSR includes contributions from associated (half-life $\leq 0.5 \mathrm{yr}$ ) daughters. 


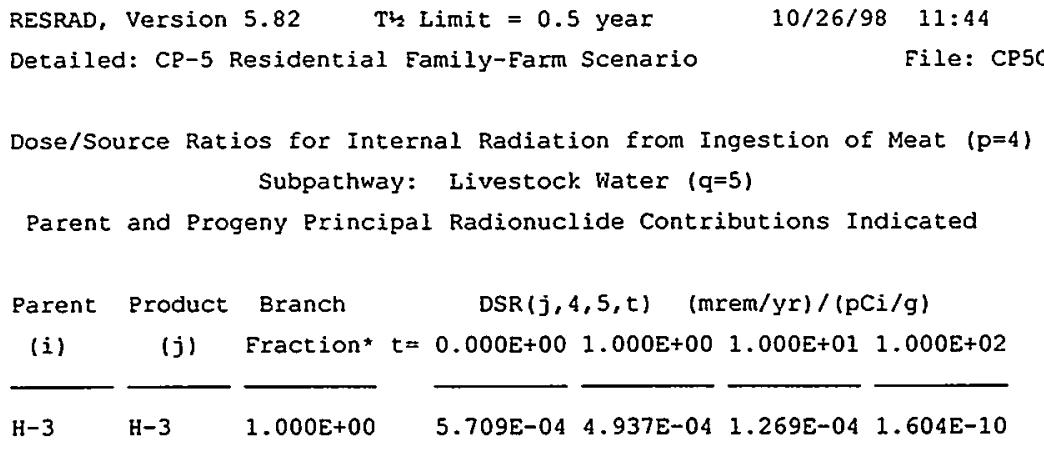




\begin{abstract}
RESRAD, Version 5.82 Th Limit $=0.5$ year
Detailed: CP-5 Residential Family-Earm Scenario

Dose/Source Ratios for Internal Radiation from Ingestion of Milk ( $p=5$ )

Subpathway: Fodder Root Uptake from Contaminated Soil $(q=1)$

Parent and Progeny Principal Radionuclide Contributions Indicated

\begin{tabular}{|c|c|c|c|c|c|c|c|}
\hline Parent & Product & Branch & & $\operatorname{DSR}(j, 5$ & $5,1, t)$ & $\mathrm{rem} / \mathrm{yr}) /(\mathrm{p} C$ & $\mathrm{Si} / \mathrm{gl}$ \\
\hline (i) & (j) & Fraction* & $t=$ & $0.000 \mathrm{E}+00$ & $1.000 \mathrm{E}+00$ & $1.000 E+01$ & $1.000 \mathrm{E}+02$ \\
\hline $\mathrm{H}-3$ & $H-3$ & $1.000 \mathrm{E}+00$ & & $0.000 \mathrm{E}+00$ & $0.000 E \div 00$ & $0.000 E+00$ & $0.000 E \div 00$ \\
\hline
\end{tabular}
\end{abstract}

10/26/98 11:44 Page 25

File: CP5OSITE.RAD

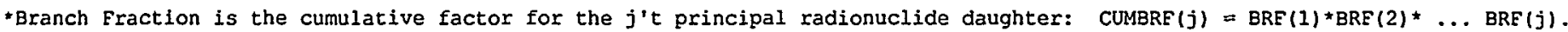
The DSR includes contributions from associated (half-life $\leq 0.5 \mathrm{yr}$ ) daughters.

Dose/Source Ratios for Internal Radiation from Ingestion of Milk ( $p=5$ )

Subpathway: Fodder Foliar Uptake from Contaminated Dust ( $q=2$ )

Parent and Progeny Principal Radionuclide Contributions Indicated

\begin{tabular}{l}
$\begin{array}{c}\text { Parent Product Branch } \\
\text { (i) }\end{array}$ \\
\hline $\mathrm{H}-3$
\end{tabular}

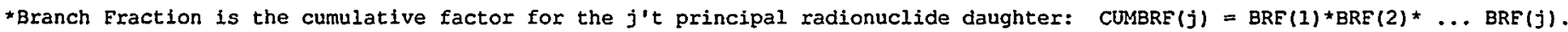
The DSR includes contributions from associated (half-life $\leq 0.5$ yr) daughters.

Dose/Source Ratios for Internal Radiation from Ingestion of Milk ( $p=5)$ Subpathway: Ditch Irrigation $(q=3)$

Parent and Progeny Principal Radionuclide Contributions Indicated

Parent Product Branch $\operatorname{DSR}(j, 5,3, t)$ (mrem/yr)/(pCi/g)

(i) (j) Eraction* $t=0.000 E+001.000 E+001.000 E+01 \quad 1.000 E+02$

\begin{tabular}{|c|c|c|c|c|c|c|}
\hline $\mathrm{H}-3$ & $\mathrm{H}-3$ & $1.000 \mathrm{E}+00$ & $2.361 E-04$ & $2.055 E-04$ & $5.284 E-05$ & $6.676 \mathrm{E}-11$ \\
\hline
\end{tabular}

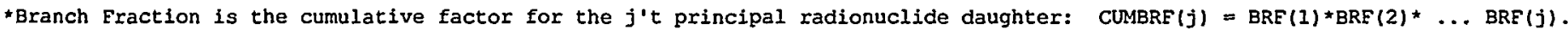
The DSR includes contributions from associated (half-life $\leq 0.5 \mathrm{yr}$ ) daughters.

Dose/Source Ratios for Internal Radiation from Ingestion of Milk ( $\mathrm{p}=5$ ) Subpathway: Overhead Irrigation ( $q=4$ )

Parent and Progeny Principal Radionuclide Contributions Indicated

Parent Product Branch $\operatorname{DSR}(j, 5,4, \mathrm{t})$ (mrem/yr)/(pCi/g)

(i) (j) Fraction* $t=0.000 E+00 \quad 1.000 E+001.000 E+01 \quad 1.000 E+02$

$\longrightarrow$ H-3

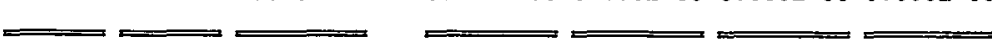

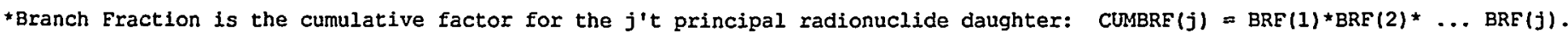
The DSR includes contributions from associated (half-life $\leq 0.5$ yr) daughters. 


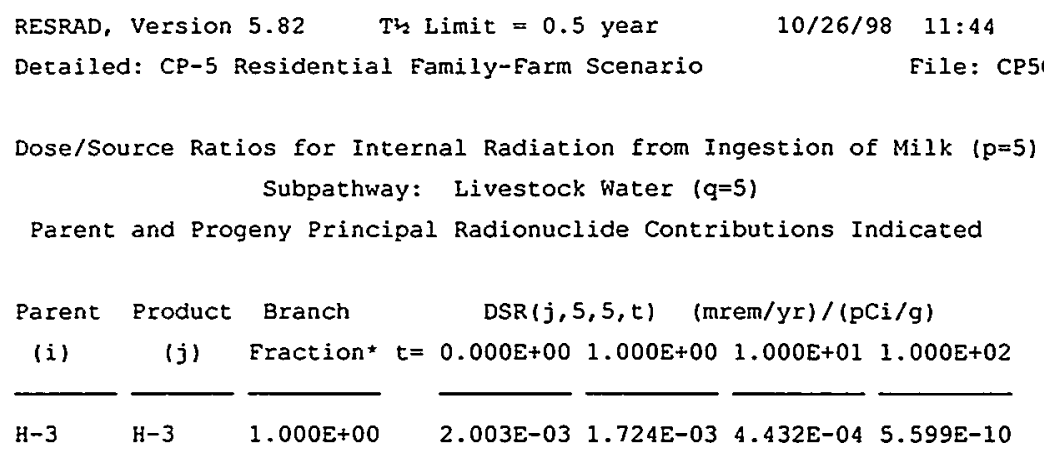


RESRAD, Version 5.82

Th Limit $=0.5$ year

Detailed: CP-5 Residential Family-Farm Scenario
10/26/98 11:44 Page 27

File: CPSOSITE.RAD

Dose/Source Ratios for Internal Radiation from the Ingestion of Fish $(p=6)$

Parent and Erogeny Principal Radionuclide Contributions Indicated

Parent Product Branch DSR $(j, 6, t) \quad(\mathrm{mrem} / \mathrm{yr}) /(\mathrm{pCi} / \mathrm{g})$

(i) (j) Fraction* $t=0.000 E+00$ 1.000E+00 1.000E+01 1.000E+02

$\mathrm{H}-3 \quad \mathrm{H}-3 \quad 1.000 \mathrm{E}+00 \quad 6.078 \mathrm{E}-06 \quad 5.236 \mathrm{E}-06 \quad 1.346 \mathrm{E}-06 \quad 1.701 \mathrm{E}-12$

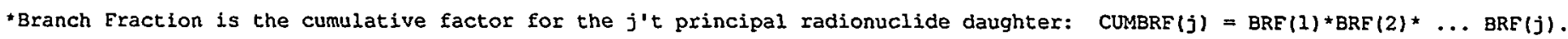
The DSR includes contributions from associated (half-life $\leq 0.5 \mathrm{yr}$ ) daughters. 


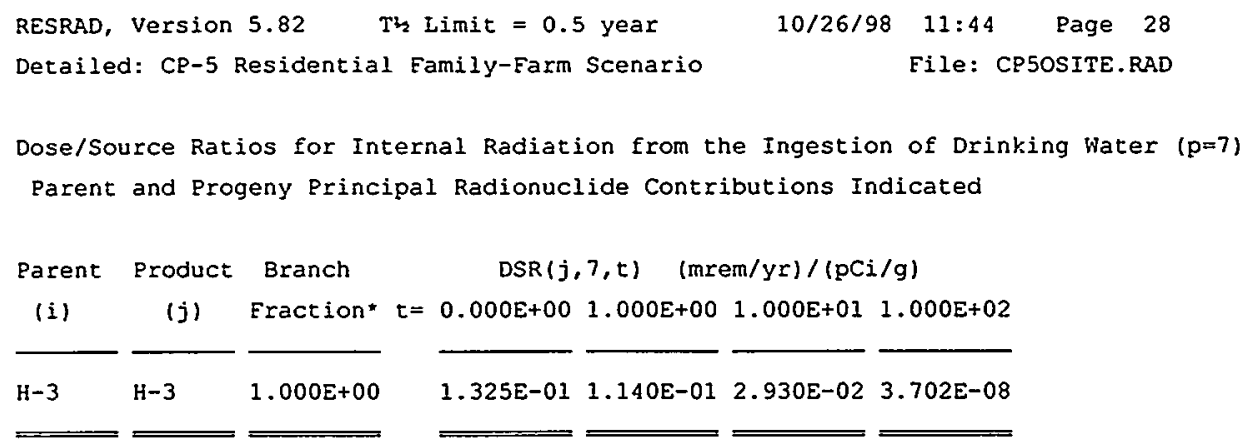




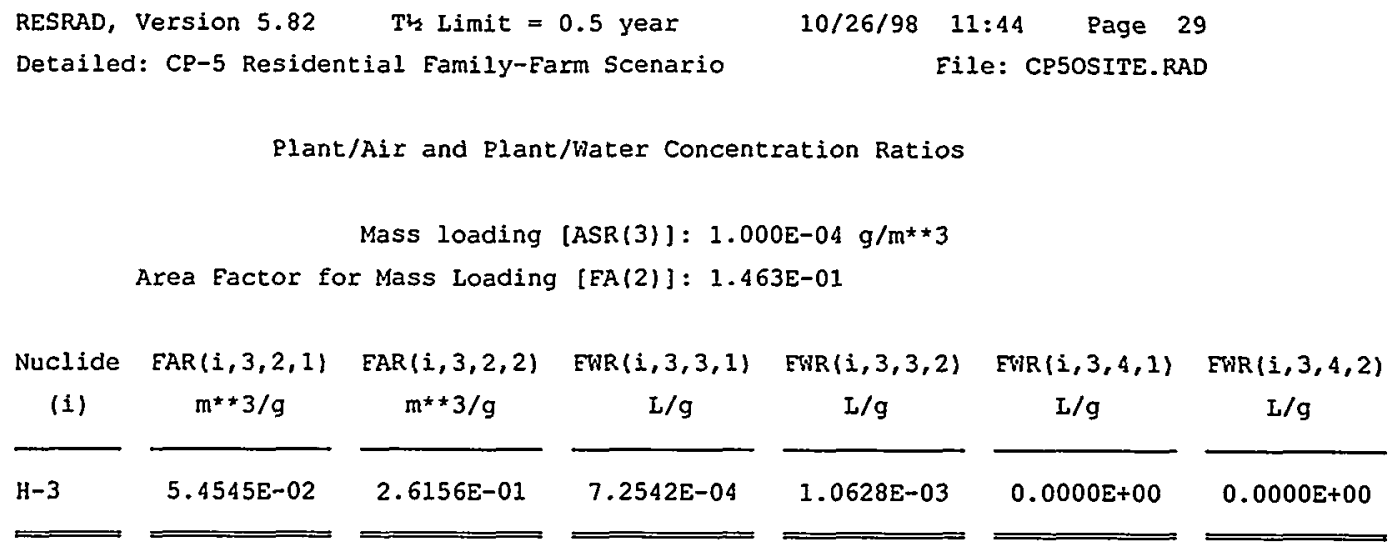

Plant/Air and Plant/Water Concentration Ratios

Mass loading [ASR $(3)]: 1.000 \mathrm{E}-04 \mathrm{~g} / \mathrm{m}^{\star \star *} 3$

Area Factor for Mass Loading [FA(2)] : 1.463E-01

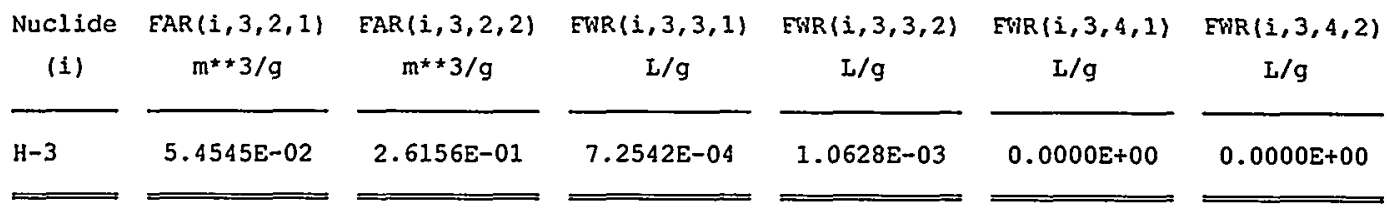

$\operatorname{EAR}(i, p, q, k)$ is the plant/air concentration ratio for airborne contaminated dust, and $\operatorname{EWR}(i, p, q, k)$ is the plant/water concentration ratio. See groundwater displays for water/soil concentration ratios.

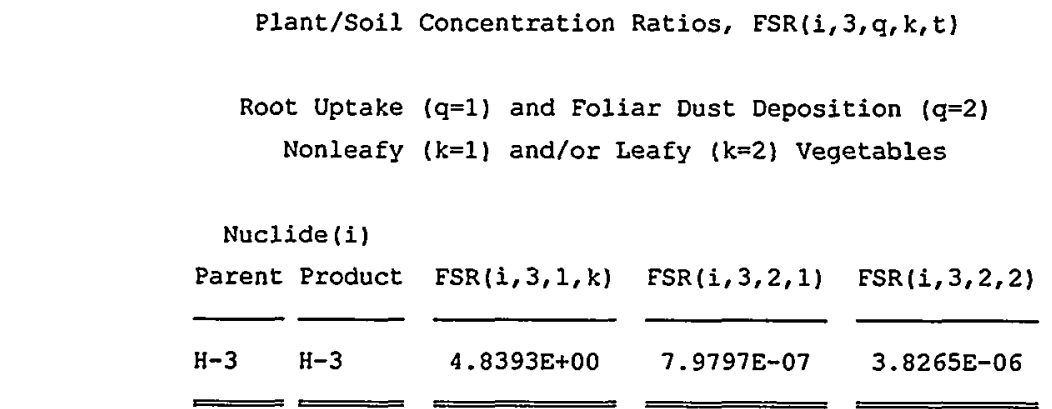

Plant/Soil Concentration Ratio, $\operatorname{FSR}(j, 3, q, k, t)$

Ditch Irrigation ( $q=3)$

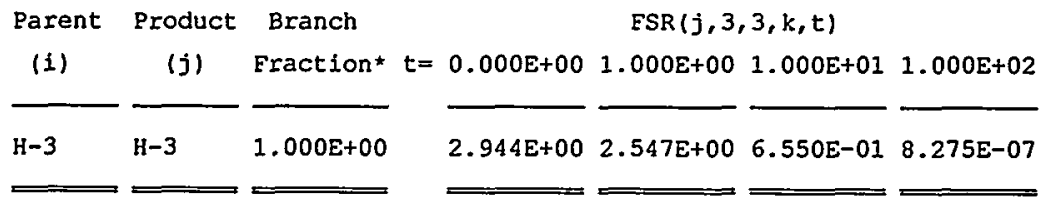

Plant/Soil Concentration Ratio, $\operatorname{ESR}(j, 3, q, k, t)$

Overhead Irrigation $(q=4)$ and Nonleafy Vegetables $(k=1)$

Parent Product Branch $\operatorname{FSR}(j, 3,4,1, t) * S F(j, t)$

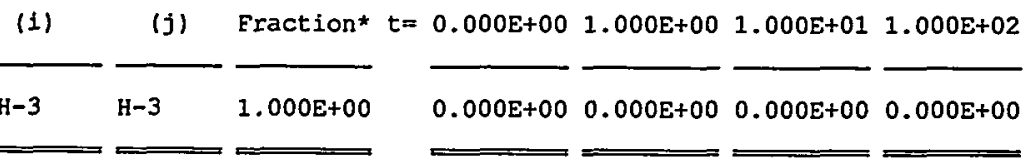

Plant/Soil Concentration Ratio, $\operatorname{FSR}(j, 3, q, k, t)$

Overhead Irrigation $(q=4)$ and Leafy Vegetables $(k=2)$

Parent Product Branch $\operatorname{ESR}(j, 3,4,2, t) * \operatorname{SE}(j, t)$

(1) (j) Eraction* $t=0.000 E+001.000 E+001.000 E+011.000 E+02$

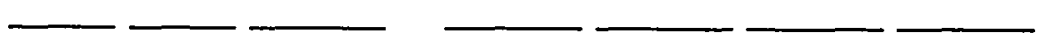




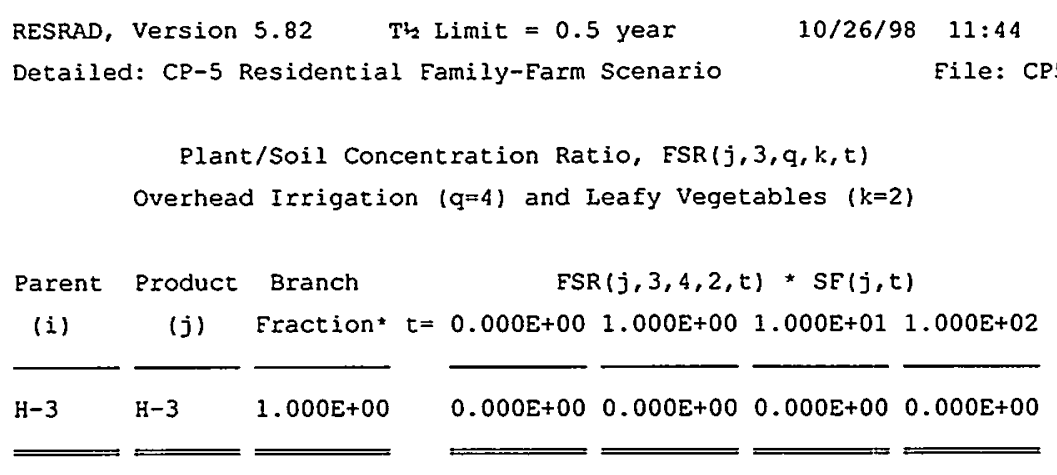




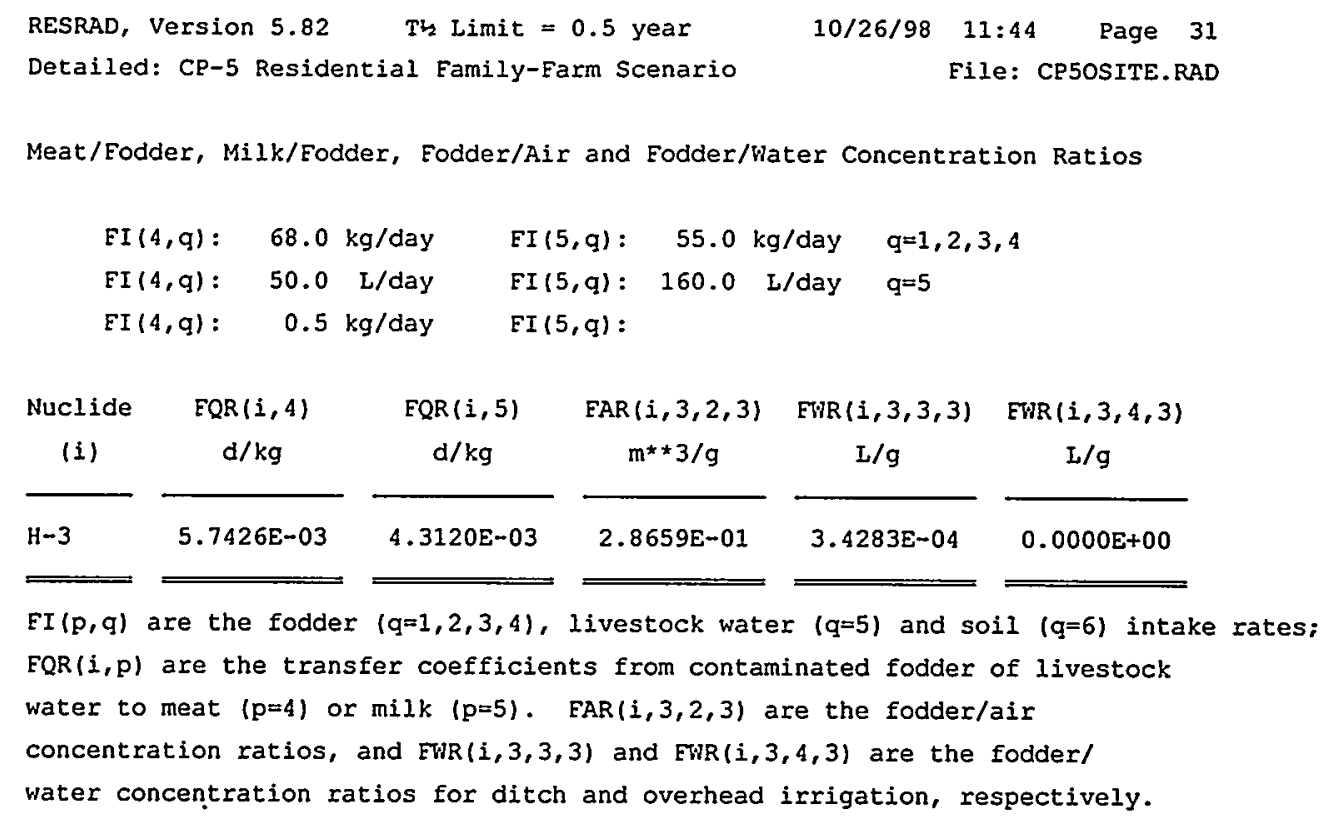




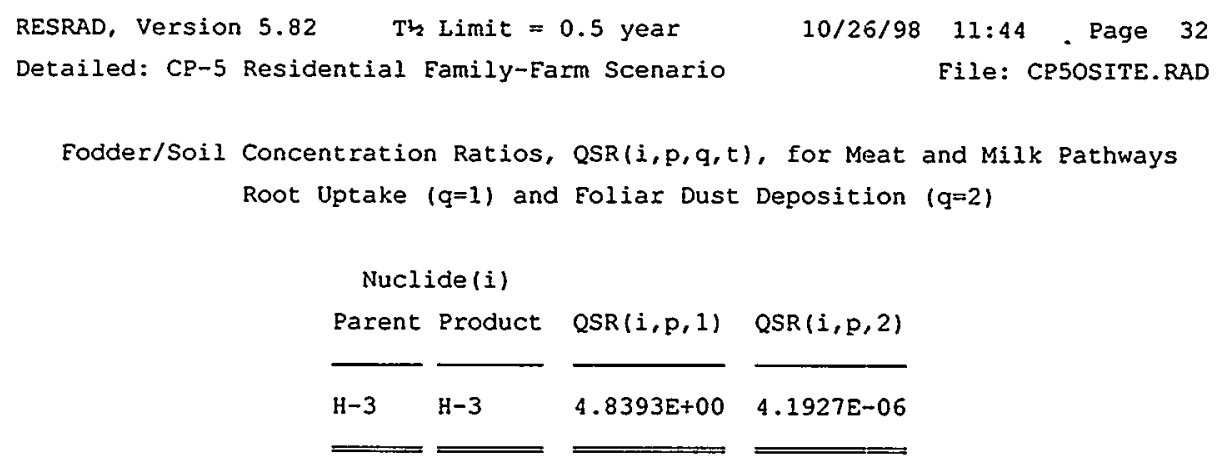

Fodder/Soil Concentration Ratio, $\operatorname{QSR}(j, p, q, t)$, for Meat and Milk Pathways Ditch Irrigation $(q=3)$

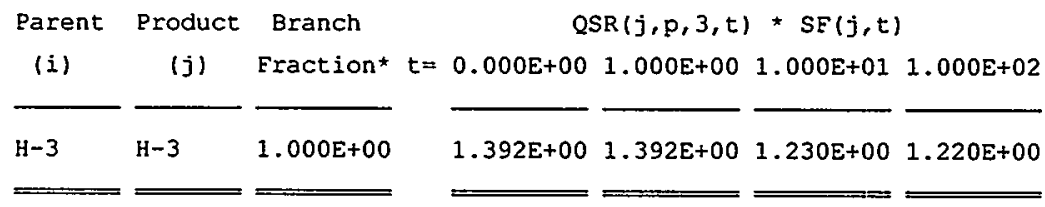


RESRAD, Version $5.82 \quad T$ Limit $=0.5$ year

Detailed: CP-5 Residential Family-Farm Scenario
10/26/98 11:44 Page 33

File: CPSOSITE.RAD

Meat/Soil Concentration Ratios, $\operatorname{FSR}(i, 4, q, t)$

Root Uptake $(q=1)$ and Eoliar Dust Deposition ( $q=2)$

\begin{tabular}{|c|c|c|c|}
\hline \multicolumn{4}{|c|}{ Nuclide (i) } \\
\hline Parent & Product & $\operatorname{FSR}(i, 4,1)$ & $\operatorname{FSR}(i, 4,2)$ \\
\hline $\mathrm{H}-3$ & $\mathrm{H}-3$ & $0.0000 \mathrm{E}+00$ & $0.0000 E+00$ \\
\hline
\end{tabular}

Meat/Soil Concentration Ratio, $\operatorname{ESR}(j, 4, q, t)$

Ditch Irrigation $(\mathrm{q}=3)$

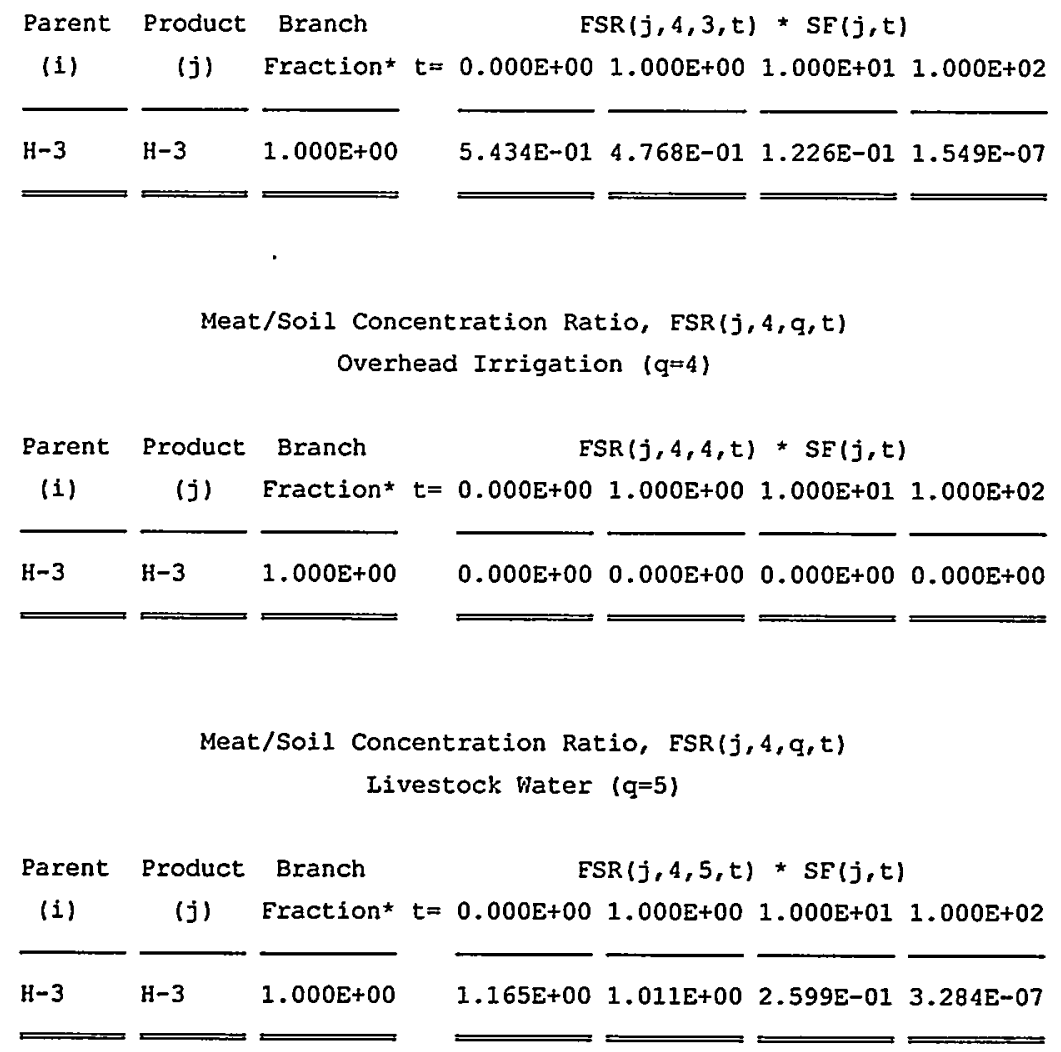


RESRAD, Version $5.82 \quad T^{2 / 2}$ Limit $=0.5$ year

Detailed: CP-5 Residential Eamily-Farm Scenario
10/26/98 11:44 Page 34

File: CP5OSITE.RAD

Milk/Soil Concentration Ratios, $\operatorname{ESR}(i, 5, q, t)$

Root Uptake $(q=1)$ and Foliar Dust Deposition ( $q=2$ )

\begin{tabular}{|c|c|c|c|}
\hline \multicolumn{2}{|c|}{ Nuclide (i) } & \multirow[b]{2}{*}{$\operatorname{ESR}(i, 5,1)$} & \multirow[b]{2}{*}{$\operatorname{FSR}(i, 5,2)$} \\
\hline Parent & Product & & \\
\hline $\mathrm{H}-3$ & $\mathrm{H}-3$ & $0.0000 E \div 00$ & $0.0000 \mathrm{E}+00$ \\
\hline
\end{tabular}

Milk/Soil Concentration Ratio, $\operatorname{FSR}(j, 5, q, t)$

Ditch Irrigation $(\mathrm{g}=3)$

\begin{tabular}{|c|c|c|c|c|c|c|c|}
\hline Parent & Product & Branch & & & $S R(j, 5,3, t)$ & $\star \operatorname{SE}(j, t)$ & \\
\hline (i) & (j) & Fraction* & $t=$ & $0.000 E \div 00$ & $1.000 \mathrm{E}+00$ & $1.000 \mathrm{E}+01$ & $1.000 \mathrm{E}+02$ \\
\hline$H-3$ & $\mathrm{H}-3$ & $1.000 \mathrm{E}+00$ & & 3. $300 E-01$ & $2.873 E-01$ & $7.388 \mathrm{E}-02$ & $9.334 \mathrm{E}-08$ \\
\hline
\end{tabular}

Milk/Soil Concentration Ratio, $\operatorname{ESR}(j, 5, q, t)$

Overhead Irrigation $(q=4)$

Parent Product Branch $\quad \operatorname{FSR}(j, 5,4, t) \star S E(j, t)$

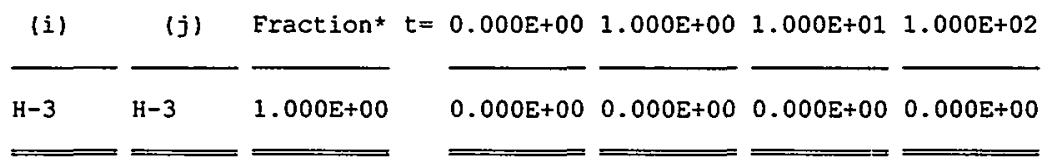

Milk/Soil Concentration Ratio, $\operatorname{ESR}(j, 5, q, t)$

Livestock Hater $(\mathrm{q}=5)$

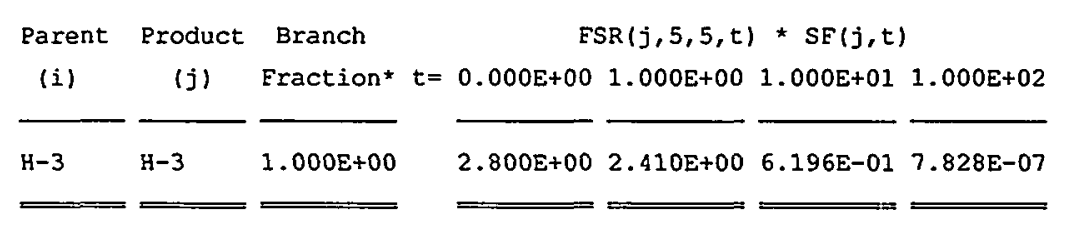




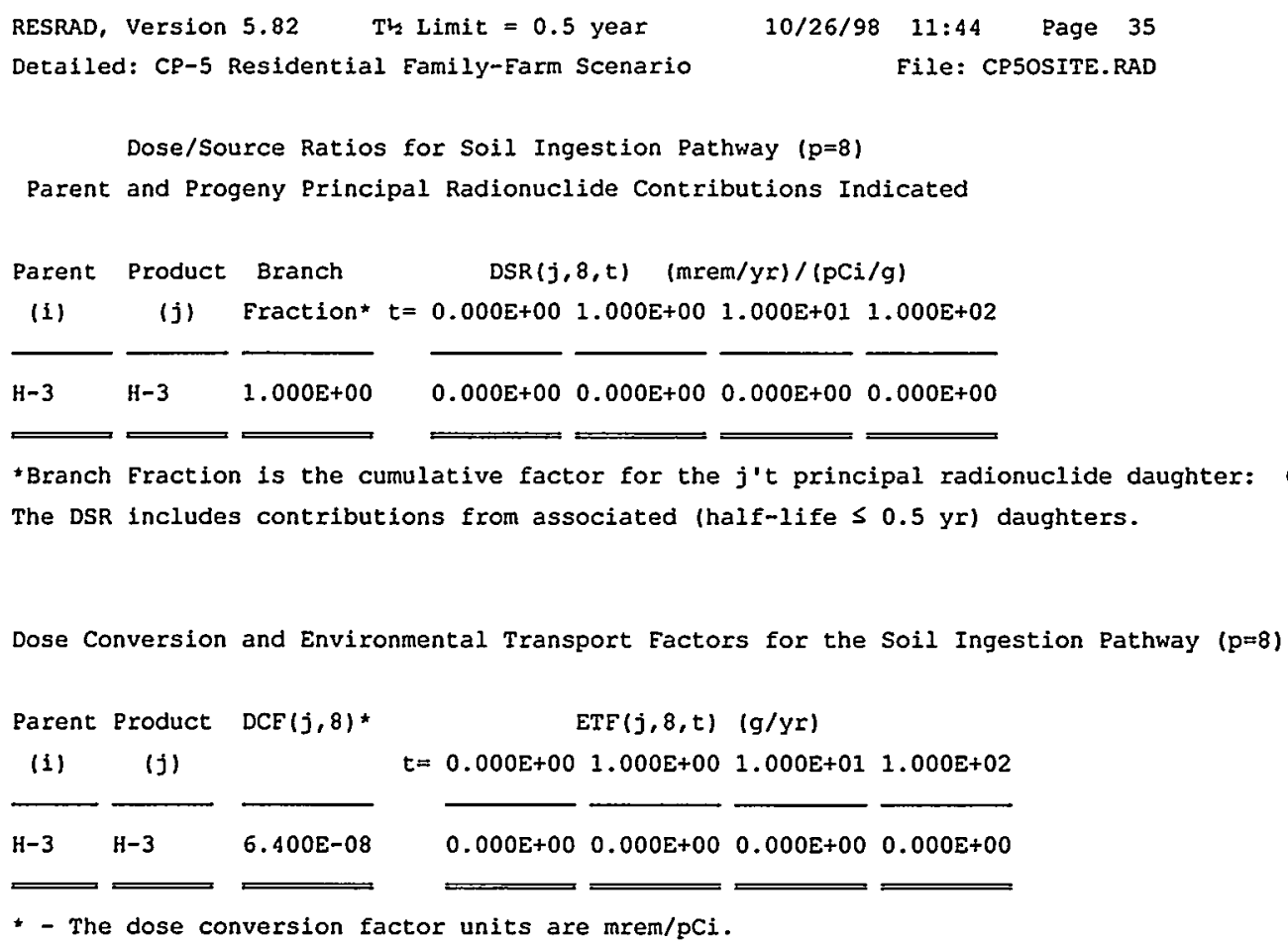

